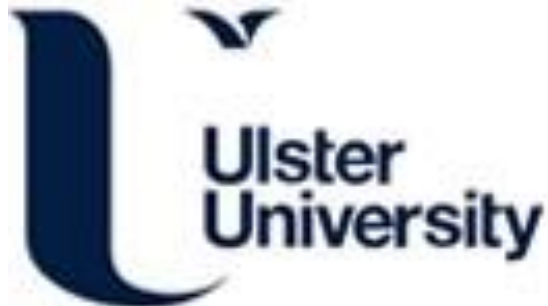

\section{Geological settings and controls of fluid migration and associated seafloor seepage features in the north Irish Sea}

Coughlan, M., Roy, S., O'Sullivan, C., Clements, A., O'Toole, R., \& Plets, R. (2021). Geological settings and controls of fluid migration and associated seafloor seepage features in the north Irish Sea. Marine and Petroleum Geology, 123, [104762]. https://doi.org/10.1016/j.marpetgeo.2020.104762

Link to publication record in Ulster University Research Portal

\section{Published in:}

Marine and Petroleum Geology

Publication Status:

Published (in print/issue): 31/01/2021

DOI:

https://doi.org/10.1016/j.marpetgeo.2020.104762

\section{Document Version}

Author Accepted version

\section{General rights}

Copyright for the publications made accessible via Ulster University's Research Portal is retained by the author(s) and / or other copyright owners and it is a condition of accessing these publications that users recognise and abide by the legal requirements associated with these rights.

\section{Take down policy}

The Research Portal is Ulster University's institutional repository that provides access to Ulster's research outputs. Every effort has been made to ensure that content in the Research Portal does not infringe any person's rights, or applicable UK laws. If you discover content in the Research Portal that you believe breaches copyright or violates any law, please contact pure-support@ulster.ac.uk. 
Petroleum Geology

Elsevier Editorial System(tm) for Marine and

Manuscript Draft

Manuscript Number: JMPG-D-19-01287R3

Title: Geological settings and controls of fluid migration and associated seafloor seepage features in the north Irish sea

Article Type: Full Length Article

Keywords: pockmark, seabed mounds, fluid seepage, MDAC, mud diapir, geohazards, ecological conservation, offshore infrastructure

Corresponding Author: Dr. Mark Coughlan,

Corresponding Author's Institution: Irish Centre for Research in Applied Geoscience

First Author: Mark Coughlan

Order of Authors: Mark Coughlan; Srikumar Roy; Conor O'Sullivan; Annika Clements; Ronan O'Toole; Ruth Plets

Abstract: Shallow gas accumulation in unconsolidated Quaternary sediments, and associated seepage at the seafloor, is widespread in the north Irish Sea. This study integrates high-resolution seafloor bathymetry and sub-surface geophysical data to investigate shallow gas accumulations and possible fluid (gas and/or liquids) migration pathways to the seafloor in the northern part of the Irish Sea. Shallow gas occurs broadly in two geological settings: the Codling Fault Zone and the Western Irish Sea Mud Belt. The gas has been recognised to accumulate in both sandy and muddy Quaternary marine near-surface sediments and is characterised by three characteristic sub-bottom acoustic features: i) enhanced reflections, ii) acoustic turbid zones, and iii) acoustic blanking. The seepage of shallow gas at the seafloor has resulted in the formation of morphological features including methane-derived authigenic carbonates, seabed mounds and pockmarks. In many instances, the evidence for this gas as biogenic or thermogenic in origin is inconclusive. Two distinct types of pockmarks are recorded in the Western Irish Mud Belt: pockmarks with a relatively flat centre, and pockmarks with a central mound. Based on our observation and existing models, we infer that the formation of a carbonate crust at the seabed surface, is needed as a precursor for the creation of such mounds within pockmarks. The formation processes are interpreted to be different for sandy versus muddy sediments, due to variability in erodibility and sealing capacities of the substrate. We suggest that the origin of these features is linked to the presence of deeper hydrocarbon source rocks with existing and reactivated faults forming fluid migration pathways to the surface. This in turn could indicate a mixed thermogenic-biogenic origin for seeprelated structures in the study area. These features have significant implications for the future development of offshore infrastructure including marine renewable energy as well as for seabed ecology and conservation efforts in the Irish sea.

Research Data Related to this Submission 
There are no linked research data sets for this submission. The following reason is given:

Data will be made available on request 
Dear Editor,

Having put considerable effort into addressing the previous set of comments, my co-authors and I are disappointed that the manuscript has not been accepted in its current format. However, we appreciate the efforts of both you and your reviewers and thank you for the time taken in making our manuscript ultimately more robust.

Having reviewed and approached the latest set of comments, we feel there is either a degree of confusion on behalf of the reviewers, or miscommunication on our part, with regard to the aims and objectives of the study, as well as the limitations of the dataset we have. As we reiterate later, currently relating to the Irish Sea there are a number of separate papers which focus on morphological features at the seabed that represent fluid/gas seepage and expulsion, as well as shallow expressions of gas accumulation (e.g. O'Reilly et al. (2014) and Van Landeghem et al. (2015)). These papers generally suggest a mixed biogenic and thermogenic component to the gas-related feature that is described. With regard to the thermogenic component, it is generally proposed and accepted that hydrocarbons generated at depth migrate along structural lineaments (i.e. faults) to the shallow subsurface. To our knowledge, there is no current geological model that integrates bedrock geology, hydrocarbon sources, structural geology, Quaternary geology and seafloor morphology in the Irish Sea. This manuscript aims to do just that in order to create a framework in which to study further aspects of the fluid migration process and feature formation. The reviewers all make relevant observations and suggestions of further work which, we feel, this framework will facilitate as part of future studies, but are currently outside the scope of this particular study.

With that in mind, we have endeavored to address each of the comments made by both reviewers, whilst more clearly detailing our aims and objectives as well as the limitations of our data with recommendations for further work. Below we make specific responses to each comment raised.

We hope that this will be agreeable with you and your reviewers and we would implore you to make a decision on this manuscript either way.

Kind Regards

Mark Coughlan (on behalf of the co-authors) 


\section{*Detailed Response to Reviewers (Revision Notes)}

\section{Reviewer 3}

1) Rev3 feels that the paper still lacks of clear evidence of fluid flow to support the arguments. To Rev3, most of the evidence is not related to migration of gas (such as the seismic amplitude anomalies) and most of the seabed features are enhanced by using contrasting color.

This paper illustrates sub-surface acoustic anomalies and seabed morphological features, which are remnants of fluid flow, migration, and seepage at the seafloor. Our study certainly lacks concrete evidence of fluid flow and seepage such as geochemical and ROV video/image grabs. However, the geophysical datasets used in this study have provided several sites of interest which we anticipate will be the target of future sampling cruises in the coming years. There are several scientific publications which, showcase acoustic and geomorphological analysis of fluid flow and seepage features. Addressing to Rev3's comments on "seabed features are enhanced by using contrasting color", we fail to see how they are considering we use standard colour schemes. Furthermore, we provide bathymetric profiles of the seabed features discussed to exhibit their cross-sectional geometry. Nevertheless, if the Editor agrees we can change the colour-scale.

With regards to seismic amplitude anomalies (presumably referring to the seabed brightening in Fig. 3 ), this is evident locally above the termination of the faults. Moreover, the entire section is presented to highlight extent of the brightening in proximity to the faults and shows the difference between normal-amplitude and high- amplitude zones within the same stratigraphic horizon. This was done with the express intention to demonstrate that this is not a lithological feature and to not mislead the reader. We would appreciate if the Editor would make a decision on whether the evidence presented is sufficient.

2) Rev3 also states that most of the pockmarks, mounds and depressions are less than a meter in height and several hundreds of meters wide ("the authors cite works, e.g., O'Reilly et al., 2014 where carbonate mounds of 5-10 meters are shown in the same area, so I am wondering why they do not take into account those studies to verify their interpretation").

Most of the pockmarks are less than a metre in height, which is consistent with other descriptions of pockmarks in Irish waters referenced in the text (Line 97: Croker et al., 2005; Games, 2001; Szpak et al., 2015, 2012). In the tabulated data regarding pockmark morphology, it is clear that all pockmarks bar one are under $200 \mathrm{~m}$ in diameter with the majority under $100 \mathrm{~m}$. Only one pockmark is hundreds of metres wide, and in Fig. 11 its outline has been marked by contoured lines to highlight its elliptical morphology. However, we have decided to remove this figure and related text from this manuscript, after critical comments from Rev3.

With regards to the carbonate mounds, we clearly refer to the interpretation documented by O'Reilly et al. (2014) and Van Landeghem et al. (2015) in lines 252-254 (of our previous submission) while drawing our interpretations on the carbonate mounds. It seems that Rev3 might have missed these lines. The mounds we illustrate in this study are not less than a meter, but 8-16 m high and $60 \mathrm{~m}$ in diameter.

3) The authors just imply that all of the features observed are gas related, with a proposed model that does not take into account any sort of mechanism for which gas migrate along fault (focused) and then suddenly as a front. 
Yes, we do propose that reactivated faults allow fluids to migrate from depth to the near surface. This migration of fluids (including gas), along faults is a well-described and generally accepted process, owing to factors such as, higher permeability along faults, buoyancy, and differential pressure. These faults are Cenozoic or older in age, therefore they typically terminated at or near the boundary with the base of the Quaternary units. Therefore, the continued migration of gas, or any fluid, towards the surface or laterally within the Quaternary units will depend on the petrophysical and geomechanical properties of those younger units.

We appreciate that in Lines 108-111 and 345-348 we could have been clearer in our objectives, scope and the limitations of this study. To date in the Irish Sea, numerous studies have described seabed morphological features linked to gas/fluid expulsion or seepage. The majority of these studies propose a thermogenic gas component and reference possible migratory pathways (i.e. faults) from deeper stratigraphic layers (source or reservoir rocks) to the surface, without offering actual evidence of fault systems (fluid migration pathways). Ultimately, the aim of this paper is the establishment of a geological framework incorporating bedrock geology, hydrocarbon source rocks, structural geology (faults), Quaternary geology and seafloor morphology in the Irish Sea which would allow investigation of subsurface fluid flow mechanisms.

We mention in the Introduction of the manuscript, that there is a mixed thermogenic and biogenic signatures documents in the CFZ and the WISMB. We also mention the thermogenic origin of the gas in the CFZ area which has migrated along faults to reach shallow stratigraphic layers and results in gas fronts and other seepage features. So, it was already evident that fluids (thermogenic gas) had a deeper source and used fault conduits to reach shallow sub-seabed sediments. However, as suggested by Rev3 and the Editor, we have now added this in the discussion of the proposed model for the formation of mounds and pockmarks.

4) Lastly, the author simply do not explain that pockmarks and mounds and other features are related to different type of fluid migration.

We have now discussed the alternative formation mechanisms of pockmarks, i.e., seepage of porewater (Harrington, 1985) - this is likely possible - particularly due to the lack of geochemical data at present to support gas seepage from the pockmarks; and fresh-water ice rafting (Paull et al., 1999) which is unlikely in the current geological setting.

Reviewer 3 in-manuscript comments

Line 80-81: gas is more compressible than water. sediments might compact more if a substantial amount of water is replaced by gas....

- We are merely highlighting what is mentioned in that reference. This is not our theory.

Line 98-99: I am wondering whether other references for the formation of pockmark can be used... - This reference refers specifically to Irish Sea pockmarks previously studied, we are happy to consider other references offered by the reviewer.

Line 312-313: this depression has just a $0.8 \mathrm{~m}$ relief over a distance of 850...this is not a pockmark!

- Again, we feel this fits with the range of previously described pockmarks referenced in the text. 
- Subjective, but we have removed this inference for the sake of progressing the manuscript.

Line 395-396: This is very speculative. The seabed shows a clear subsidence that can produce space and increase the thickness of the near-seabed sediments, and from here produce tuning anomalies. If long migration from the deeper part of the basin is invoked, I am wondering why no gas is visible underneath these amplification. This is to me a very weak argument.

- The text has been amended to address this in Lines 402-407

Line 419: No, it does not!

- Text amended

\section{Reviewer 5}

1) It is important to clarify he processing strategy which has been used for those seismic data: if some amplitude preservation type processing has not been applied (excluding any modification of the amplitude calibration or NMO) to me the amplitude analysis through the stacked trace can produce ambiguities. I will clarify my comments a bit more precisely further on point " $x y$ ".

To reiterate, the sub-bottom profiler data presented is single-channel. All processing steps have been outlined in the "Sub-bottom acoustic data" section of the manuscript, including the velocity values used

2) Figure $6 b$ - Multibeam : The proportion of acoustic energy reflected back from the seabed is determined by the impedance contrast, sometimes referred to as 'hardness' and apparent surface roughness scale. the question is how the $d B$ intensity variation can be correlated to gas content other than hardness or roughness of the seabed. and this is where i believe the author should better discuss their results. There is a huge lot of literature which generally assign high backscatter intensity with rock or coarse-grained sediment, and low backscatter intensity characterizes finer grained sediments. But given the nature of the seabed and the physics nature of the backscatter variation a $d B$ relative scale is not enough to add petrophysics values to the images. without ground-truthing it is not possible to determine the exact nature of the specific substrates. So Fig $6 B$ i am questioning what in reality figure $6 b$ is telling to us. While the other images included in Fig 6 are seabed morphological maps $6 b$ it is not simply that. The authors should make some effort to clarify the nature of this backscattered signal or not include this figures. In fact if the two mound, at seabed condition where compaction is excluded, are saturated by gas..they should soften the p sonar impedance and therefore i expect to have the way around in term of signal: not shadowing. so it has to be a hardening but the fluid content being secondary here. To me the nature of the mounds remains very speculative..

To be clear, in this study we use the multibeam backscatter data as a means to identify areas of seabed hardness relative to surrounding softer substrate (coarse-grained sediments vs. soft sediments), and not a means to identify gas-saturated sediments. We agree with Reviewer 5 in that, ultimately, these features need to be ground-truth. But, in the absence of such data (ROV images of the mounds), we refer to previous studies where similar mounds in the vicinity of our study area have been confirmed as remnants of gas seepage (i.e. O'Reilly et al., (2014); Van Landeghem et al., 2015). Hence, our interpretation of the features in Figure 6 is in keeping with those of O'Reilly et al. (2014); Van Landeghem et al. (2015) for this area, as indicated in the main text of the manuscript. 
3) Fig $11 \mathrm{~B}$. the same consideration apply to figure $11 \mathrm{~B}$. But I do not exclude the proposed interpretation, of carbonate precipitation which geologically (given the strat context given by the authors) and petrophysically is plausible.

Again we agree that, ideally, this would be groundtruthed, but we have no such data at present. In any case Fig. 11 has been removed to negate further confusion.

4) Fig 9; how is it produce the surface with colour scale in mbsf (so in depth).? what are the data source for this surface? the author refer to $2 D$ seismic and sparkers line..buty no other $3 D$ source of data

The 3D surface of the depth to the top of shallow gas displayed in Fig. 9 was generated from a sparker seismic grid detailed in Fig. 1 of Coughlan et al. (2019). We hope that the editor would agree to the fact that we can generate a 3D surface from a dense grid of 2D sparker seismic lines. We have added additional text in the figure caption of Fig. 9 to emphasize the same. To avoid unnecessary replication, the reader is referred to that paper for details of the data used and processing steps (Lines 292-294).

5) Figs 10 ; those to me represent crucial images. they are sparker seismic lines crossing the potential top of a gas cumulations surrounded by pockmarks. What I do not find that convincing is the seismic expression of what the authors call Enanced reflections:

the enhanced reflection in figure $10 \mathrm{~b}$ are all of the same polarity of the seabed.. which is not what $i$ expect in case of gas cumulation in a shallow environment whenre unconsolidated shale/sand should roughly respond with shale stronger than sand and therefore any sand saturated by gas produce reflector with reverse polarity respect to the seabed. I am not sure they represent a convincing stacked reflection ( or what in the literature Foschi et al., define amplitude anomalies stacked structure) deriving from gas anomalies. I believe the authors should more precisely discuss all the options out of the what the data proposed are indicating. Morover $i$ believe that some sort of partial stack or AVO should be added in one of those enhanced reflectors and cross the major mounds as gas has in the shallow context a crystal clear footprint in the AVO.

Firstly, in relation to Fig. 10, it is important to note that the data presented here is shallow $(<50 \mathrm{~m})$ single-channel sparker data, and not conventional 2D multichannel seismic data - where we look for polarity reversals as an indicator to the presence of shallow gas or gas hydrates. AVO analysis is not feasible on single-channel sparker data, as far as we are aware of.

With regards to the enhanced reflectors, these occur within localised areas of acoustic turbidity, and above zones of acoustic blanking on the seismic profile. This is consistent across a number of seismic profiles from this area presented in this paper and Coughlan et al. (2019). The presence of acoustic turbidity and blanking infer the presence of shallow gas, which is why we are presenting this evidence. Our identification of features as "enhanced reflection" horizons is consistent with other work (i.e. Judd and Hovland, 1992), but if Reviewer 5 wishes to direct us towards additional literature in this area we will gladly review and consider it. For now, our main concern would be that there is agreement on the presence of shallow gas, enhanced reflections notwithstanding. 
6) the only image that i found convincing is figure 14. it shows the only clear potential gas chimney and acoustic blanketing..suggesting that some of those feature imaged in figure 13 may represent pockmark out of other (the linea sequence of seabed mounds may still represent sedimentary features..) which are not that convincing

We are slightly confused by this comment. Our understanding is that the reviewer is satisfied with our interpretation of shallow gas at Queenie Corner from the seismic profile and that of gas chimneys (which clearly cause seabed mounds on the same profiles), but maintains the corresponding features on bathymetric data may still be sedimentary (Location of seismic line Fig. 14 is shown on Fig. 13 clearly). We feel that there is enough evidence to spatially link the subsurface gas accumulation (imaged as enhanced reflections and turbidity zones) and gas migration (imaged as gas chimneys) in Fig. 14 to the seafloor mounds in Fig. 13. Of course they may still represent sedimentary features as the reviewer suggests, but again we suggest the evidence of shallow gas beneath the mounds is compelling, and in lieu of other available data, this interpretation is the most plausible in our view. As the reviewer mentions about the linearity of the mounds, similar seabed mound features, $2-6 \mathrm{~km}$ long seabed mounds have been documented in the Alboran Sea owing to thermogenic fluid migration (Comas and Pinheiro, 2007)

7) So i believe that the authors at this stage should put some more effort at describing the data proposed and on that ground discuss all the potential implication of those ambiguities Overall the paper is extremely interesting, in fact I like the discussion of the implication of the interpretation and seismic within a site survey approach which should in fact, if this is the message the authors would like to convey, have been introduced at the start: an overview of the issues with reconnaissance of the shallow gas but also the application of those techniques in a contest of site surveying and de risking. there a few paper on that subject and in the future more will appear. In this context a failure by the authors in convincing that all those mound or enhanced reflections features may really represent gas intrusion should not hinder the paper: in fact it should remain a nice rigorous case history showing the problem of ambiguities in a shallow context where the data available are multibeam sonar, sparkers and only a limited amount of good conventional seismic data may not be crystal clear.

We agree with Reviewer 5 on this point and appreciate their comments and suggestions. We have taken these under consideration and made the following revisions accordingly:

1. We have added a section in the Discussion on "Data and geological model limitations" where we discuss the limitations of the data used and the ambiguities introduced;

2. Made recommendations on future data collection in the Conclusions and Recommendations section to overcome these ambiguities.

The Lead Author would also like to offer that, on the basis of the limitations of the data highlighted, an additional survey in this area was undertaken in July 2020 using targeted site investigation techniques (including multichannel sparker seismic) which should clarify some of the ambiguities mentioned in this study. The data from this survey is part of an ongoing project, analysis of the acquired data would take considerable amount of time, and cannot be completed in the near future (hence not be included in this study).

References 
Comas, M., and Pinheiro, L. M., Discovery of carbonate mounds in the Alboran Sea: the Melilla mound field, in Proceedings 1st International Conference of the Moroccan Association of Petroleum Geologists (MAPG) in association with the American Association of Petroleum Geologists (AAPG), Marrakesh, October2007, p. 28-31.

Harrington, P. K., 1985, Formation of pockmarks by pore-water escape: Geo-Marine Letters, v. 5, no. 3, p. 193-197.

Paull, C. K., Ussler lii, W., and Borowski, W. S., 1999, Freshwater ice rafting: an additional mechanism for the formation of some high-latitude submarine pockmarks: Geo-Marine Letters, v. 19, no. 1, p. 164-168. 
- An integrated methodology is used to assess fluid flow in the north Irish Sea

- Characterisation of a previously undocumented accumulation of shallow gas in Quaternary sediments, 17 new pockmarks and an area of seabed mounds

- New mechanisms proposed for pockmark and seabed mound formation for this location

- Cenozoic faulting and re-activation of older faults generates pathways for deep fluids to migrate to the shallow sub-surface

- At the seabed, sediment properties play a strong role in the morphological expression of fluid seepage structures 


\section{Geological settings and controls of fluid migration and associated seafloor 2 seepage features in the north Irish Sea}

3 5

$6{ }^{1}$ School of Civil Engineering, University College Dublin, Newstead, Belfield, Dublin 4, Ireland.

$7 \quad{ }^{2}$ School of Earth Sciences, Science Centre West, University College Dublin, Belfield, Dublin 4, Ireland.

$8{ }^{3}$ Irish Centre for Research in Applied Geosciences, O'Brien Centre for Science East, University College

9 Dublin, Belfield, Dublin 4, Ireland

$10{ }^{4}$ Seafish, 18 Logie Mill, Logie Green Road, Edinburgh.

$11{ }^{5}$ Geological Survey of Ireland, Beggars Bush, Dublin, Ireland

$12{ }^{6}$ School of Geography and Environmental Sciences, Ulster University, Coleraine, Northern Ireland.

13 7Flanders Marine Institute, Wandelaarkaai 7, 8400 Ostend, Belgium

\section{ABSTRACT}

Shallow gas accumulation in unconsolidated Quaternary sediments, and associated seepage at the seafloor, is widespread in the north Irish Sea. This study integrates high-resolution seafloor bathymetry and sub-surface geophysical data to investigate shallow gas accumulations and possible fluid (gas and/or liquids) migration pathways to the seafloor in the northern part of the Irish Sea. Shallow gas occurs broadly in two geological settings: the Codling Fault Zone and the Western Irish Sea Mud Belt. The gas has been recognised to accumulate in both sandy and muddy Quaternary marine near-surface sediments and is characterised by three characteristic sub-bottom acoustic features: i) enhanced reflections, ii) acoustic turbid zones, and iii) acoustic blanking. The seepage of shallow gas at the seafloor has resulted in the formation of morphological features including methane-derived authigenic carbonates, seabed mounds and pockmarks. In many instances, the evidence for this gas as biogenic or thermogenic in origin is inconclusive. Two distinct types of pockmarks are recorded in the Western Irish Mud Belt: pockmarks with a relatively flat centre, and pockmarks with a central mound. Based on our observation and existing models, we infer that the formation of a carbonate crust at the seabed surface, is needed as a precursor for the creation of such mounds within pockmarks. The formation processes 
31 are interpreted to be different for sandy versus muddy sediments, due to variability in erodibility and

32 sealing capacities of the substrate. We suggest that the origin of these features is linked to the presence

33 of deeper hydrocarbon source rocks with existing and reactivated faults forming fluid migration

34 pathways to the surface. This in turn could indicate a mixed thermogenic-biogenic origin for seeprelated structures in the study area. These features have significant implications for the future development of offshore infrastructure including marine renewable energy as well as for seabed ecology and conservation efforts in the Irish Sea.

Keywords: pockmark, seabed mounds, fluid seepage, MDAC, mud diapir, geohazards, ecological conservation, offshore infrastructure

\section{INTRODUCTION}

The accumulation of gas in shallow, unconsolidated marine sediments is aa global phenomenon (Andreassen et al., 2007; Dondurur et al., 2011; Ergün et al., 2002; Hovland and Judd, 1992; Karisiddaiah and Veerayya, 1994; Mazumdar et al., 2009). It represents an important tool for frontier hydrocarbon exploration, while also posing a significant geohazard, affecting sediment engineering properties (Andreassen et al., 2007; Hovland et al., 2002; Sills and Wheeler, 1992). The impacts of shallow gas and seepage on seabed ecology has also gained importance over the recent years (Jordan et al., 2019; Kiel, 2010; Rathburn et al., 2000). To date in the Irish Sea (Fig. 1), a number of areas associated with shallow gas and fluid seepage have been designated as Special Areas of Conservation (SAC) due to the unique habitats they form as "Submarine structures made by leaking gases", according to the Annex I / II of the E.U. Habitats Directive (National Parks and Wildlife, 2015). These can form two described habitat types: Bubbling Reefs and Structures within Pockmarks. In the Irish Sea, the SAC areas are predominantly related to Methane-Derived Authigenic Carbonates (MDAC) and are known locally as the Codling Fault Zone (CFZ) SAC and Croker Carbonate Slabs (CCS) SAC (Fig. 1). Further north, Queenie Corner is an offshore site within the Western Irish Sea Mud Belt (WISMB) that was designated as a UK Marine Conservation Zone (MCZ) in 2019 for its subtidal mud habitat and sea-pen and burrowing megafauna communities (Clements and Service, 2016).

Shallow gas in unconsolidated marine sediments can have a biogenic or thermogenic origin. Bulk isotopic analysis on samples from the CFZ by O'Reilly et al. (2014) indicate a biogenic origin of the seeping gas, with some possible thermogenic contribution from underlying Carboniferous coal deposits. 
Methanogenesis of organic-rich Quaternary sediments has been proposed as a source for shallow gas in Bantry Bay (Jordan et al., 2019) and Dunmanus Bay (Szpak et al., 2015) elsewhere in Irish waters. Evidence for shallow gas accumulations and seepage in the Irish Sea has been detected from geophysical observations on seismic lines as gas chimneys, enhanced reflectors and acoustic turbidity (e.g. Judd and Hovland (1992)). Where fluids (e.g. methane gas) emanate from the seabed, morphological features such as mounds and pockmarks have formed in the Western Irish Sea (Croker et al., 2005).

Mounds are elevated bathymetric features which can form due to upward migrating fluids exerting pressure on overlying relatively impermeable layers or precipitation of carbonates due to prolonged methane gas seepage. Owing to their different formation mechanism, they are known as seabed domes, mud diapirs, and carbonate mounds, all of which have been found in the Irish Sea (Croker et al., 2005). Hovland and Curzi (1989) documented seabed domes and mud diapirs in the Adriatic Sea offshore Italy, where gas bubbles concentrating in plastic clay caused local density reversals, resulting in the upward buoyant flow of the clay and deformation of overlying unlithified layers, thus forming elevated bathymetric features at the seafloor and associated gas seepages. Such seabed domes and mud diapirs have also been found offshore India (Ramprasad et al., 2011), in Norwegian Arctic fjords (Roy et al., 2014), and offshore New Zealand (Koch et al., 2015). Croker et al. (2005) previously mapped mounds (referred to as "seabed doming") in the WISMB, and suggested that they may have formed due to the replacement of water in the pore space with gas causing an increase in sediment volume in the upper sediment layers. For this to occur, fine-grained, relatively impermeable sediments are required. Croker et al. (2005) also suggested that seabed doming might be an initial stage of pockmark formation. Mounds can also form when prolonged methane gas seepage at the seabed chemically interacts with surrounding minerals to form a carbonate precipitate cement (MDAC), binding the sediment matrix and forming hard, resistive rocks (Judd et al., 2019). With continued seepage over time, MDACs can continue to precipitate and grow into sizeable features up to $10 \mathrm{~m}$ high and $250 \mathrm{~m}$ in length, as found at the CFZ in the western Irish Sea (O'Reilly et al., 2014).

Pockmarks are the most common manifestations of fluid seepage on the seafloor and are formed by fluids escaping through the seafloor sediments (Hovland and Judd, 1988). Unconsolidated sediments at the seafloor are lifted and winnowed by the escaping fluids (pore water or gas) forming crater-like depressions. Their shapes are typically circular to sub-circular, however, asymmetric, elongated and trough-like pockmarks have also been documented (Judd and Hovland, 2007; Roy et al., 2015). 
extensional events in the Carboniferous, Permian and Jurassic, punctuated by episodes of uplift during the Late Carboniferous Variscan Orogeny and more recently the Alpine Orogeny during the Cenozoic. During the Cenozoic event, the Irish Sea experienced kilometre-scale uplift resulting in the present-day configuration of erosional outliers, which are remnants of a much larger rift system (Jackson and Mullholland, 1993). These rift basins include the Kish Bank Basin and Peel Basin, both of which have been the focus of hydrocarbon exploration during the last fifty years (Fig. 1) (Dunford et al., 2001; Newman, 1999). Lithologies capable of generating hydrocarbons have been encountered in the Carboniferous, including the gas-prone Pennine Coal Measures Group and the oil-prone Bowland Shale Formation (Fig. 2). These source rocks have generated significant quantities of hydrocarbons, with an estimated 1.8 BBOE (Billion Barrels of Oil Equivalent) discovered in the East Irish Sea Basin (Bunce, 2018). Similar exploration activities took place in the western Irish Sea, primarily in the Kish Bank Basin, with four wells drilled between 1977 and 1997. While no commercial discoveries were made, the presence of the Pennine Coal Measures Group was proven in the 33/22-1 well on the southern margin of the Kish Bank Basin (Thomas, 1978).

The bedrock in the Irish Sea has largely been blanketed with Quaternary sediments, collectively referred to as the Brython Glacigenic Group (Fig. 2). Subglacial sediments deposited by the Irish Sea Ice Stream (ISIS) during the Last Glacial Maximum are referred to as the Upper Till (UT) member (Fig. 2), and comprise a till containing stiff or hard clay with clasts ranging in size from sand-grade to boulders up to 1 m (Jackson et al., 1995). Overlying the UT are a series of units deposited in a glaciomarine to marine environment as the ISIS retreated, referred to as the Western Irish Sea Formation (WISMF) (Fig. 2) (Jackson et al., 1995). Included in this formation, at the base, is the Chaotic Facies (CF). This unit consists of ice-proximal sediments, dominated by gravels with silts, sands and cobble-grade components (Coughlan et al., 2019; Jackson et al., 1995). The overlying Prograding Facies (PF) is composed of fine- to medium-grained sands that are tabular stratified, having been deposited in a marine environment in front of the retreating Irish Sea Ice Stream (ISIS) (Coughlan et al., 2019; Jackson et al., 1995). The Mud Facies (MF) is characterised by stratified grey-brown muddy sands with silts and clays and is interpreted as being deposited in a fully marine environment (Coughlan et al., 2019; Woods et al., 2019). The organic-rich sediments of the MF have been identified as a potential source of shallow gas (biogenicorigin) in the north Irish Sea in the Western Irish Sea Mud Belt. The anaerobic decomposition of the organic-rich sediments followed by rapid burial under high sedimentation rates during marine transgression in the Early Holocene produced biogenic gas in the shallow sediments (Yuan et al., 1992). 
The UT and WISF deposits have been reworked during marine transgression and sea-level rise in the Holocene forming a complex distribution of sediments and bedforms, collectively referred to as the Surface Sands Formation (SSF) (Fig. 2) (Jackson et al., 1995; Ward et al., 2015).

\section{DATA AND METHODS}

This study uses a variety of shallow and deep geophysical datasets. The shallow datasets used in this study include multibeam echosounder (MBES) bathymetry and backscatter data as well as shallow sparker and pinger seismic data from a variety of surveys (Table 1). They were acquired primarily as part of the Integrated Mapping for the Sustainable Development of Ireland's Marine Resource (INFOMAR) programme, delivered by the Geological Survey of Ireland (GSI) and Marine Institute of Ireland. Data collected by the Agri-Food and Biosciences Institute (AFBI) in collaboration with GSI and by a Natural Environment Research Council (NERC) sponsored survey (NE/H02431/1) is accessed for Queenie Corner. A combination of ArcGIS, IVS Fledermaus, IHS Kingdom and Petrel software were used to analyse and integrate these datasets for a complete sub-surface to seafloor analysis.

\section{Multibeam echosounder data}

The high-resolution multibeam datasets were collected with the EM3002D multibeam echosounder (MBES) onboard the RV Celtic Voyager (dual head) and RV Corystes (single head) acquiring bathymetry data in the $300 \mathrm{kHz}$ range using dynamically focused beams. The horizontal accuracy $(x, y)$ was usually less than $50 \mathrm{~cm}$ with a vertical accuracy $(\mathrm{z})$ of $<15 \mathrm{~cm}$ obtained for the processed bathymetry data. Data processing was performed on board with the CARIS HIPS and SIPS software package to remove erroneous pings and correcting for tidal and water displacement offsets. The output from the CARIS HIPS and SIPS software consisted of un-gridded, tidally corrected XYZ data that was subsequently gridded using QPS Fledermaus v.7 to a $2 \mathrm{~m}$ cell resolution. Gridded raster data was then exported to ArcGIS v10 and Fledermaus v.7.7.6 for 3D visualization and morphological analysis of seafloor features. Relative backscatter values were obtained from the strength of the return signal during MBES acquisition. Data were processed using Geocoder in CARIS HIPS and SIPS and exported into ESRI ArcGIS in gridded formats.

\section{Sub-bottom acoustic data}


Seismic sparker data were gathered using a Geo-Source 400 sparker system. The system consisted of a 6 kJ pulsed power supply operating predominantly at a frequency of $0.5-2 \mathrm{kHz}$. The unfiltered return signal was picked up using a Geo-Sense single channel hydrophone array. A maximum penetration of 50

\section{D multichannel seismic data}

The 2D multichannel reflection seismic data used in this study consisted of a multi-vintage database of six surveys acquired as part of the hydrocarbon exploration activities in the Irish sea. These seismic surveys were acquired between 1983 and 1995, comprising over 2,800 kilometres of data, and processed as per industry standards (Yilmaz, 2001). The majority of the seismic data are centred on the Kish Bank Basin, with five 2D seismic surveys not extending significantly beyond the bounds of the basin. Coverage of the remainder of the study area is provided by a single reconnaissance survey acquired by WesternGeco in 1983, which covers the entirety of the Irish sector of the Irish Sea. Stratigraphic control is provided by four deep boreholes drilled to test for hydrocarbons in the Kish Bank Basin. Data associated with these boreholes consists of wireline logs (gamma ray, caliper, neutron-density, sonic, and resistivity logs), well completion reports, formation tops, and time-depth relationship data in the form of checkshots. Seismic interpretation of key stratigraphic horizons and seismic to well tie was carried out in Petrel software.

\section{RESULTS AND INTERPRETATION}


A 2D multichannel reflection seismic dataset, consisting of several discrete surveys, was used to investigate the bedrock geology of the region, structural lineaments and gas related features. Six key horizons were mapped in the vicinity of the Lambay Deep and Kish Bank Basin where formation tops from four hydrocarbon exploration boreholes provided stratigraphic control: (i) Seabed; (ii) BaseQuaternary; (iii) Base-Cenozoic; (iv) Top Lower Triassic; (v) Top Permian; (vi) Top Basement

224 (Carboniferous \& older) (Fig. 1 and Fig. 3).

Where the Codling Fault Zone transects the Kish Bank Basin, a number of seismic amplitude anomalies are observed in the upper Cenozoic section. These seismic amplitudes are locally distributed, including distinct seabed brightening and widespread reverse-polarity anomalies (Fig. 3). These features are confined to the Codling Fault Zone and are not observed in other areas of the Kish Bank Basin. They cause acoustic blanking of the deeper section, either due to absorption or reflection of acoustic energy, significantly reducing seismic image quality at depth. Absorption of acoustic energy can be caused due to presence of gas in the upper stratigraphic sediments, whereas reflection could be attributed to the presence of high-density rocks such as igneous bodies. The latter is unlikely, as igneous bodies have not been documented in the upper Cenozoic sediments in this part of the Irish Sea.

There is limited stratigraphic control beyond the Kish Bank Basin, towards the Peel Basin (Fig. 1). Data quality is poor here, owing to the limited reflectivity within the Palaeozoic section. Therefore, only the Base-Cenozoic unconformity could be reliably interpreted. A small half-graben was identified in the north of the study area (i.e. the WISMB; Fig. 1 and Fig. 4) which at present remains undrilled. Owing to its location along strike from the Peel Basin in the UK sector of the Irish Sea, this minor graben is interpreted as an erosional outlier, and the stratigraphy is inferred to be Permian and Triassic, similar to that of the Peel Basin (Floodpage et al., 2001). The bounding faults of this small graben are observed to offset the Base-Cenozoic surface, indicating relatively recent tectonic activity, and the areal extent of this graben correlates with the extent of the acoustic turbidity mapped on sub-bottom profiler sections (Fig. 4).

Further east within the WISMB, underlying the Queenie Corner area, a 2D reflection seismic line images folded Carboniferous rocks at depth, overlain by Cenozoic sediments (Fig. 5). Similar to structures 249 observed in Fig. 3, several minor faults are observed offsetting the Base-Cenozoic Unconformity and 250 represent relatively recent tectonic activity (Fig. 5). 
Multibeam and Sub-bottom acoustic data

\section{Codling Fault Zone}

The seabed in the Codling Fault Zone is dynamic with extensive sediment waves (Croker et al., 2005) (Fig. 6). Also prominent are mounds, which form distinctive bathymetric highs relative to the surrounding seafloor. Approximately 23 mounds have been described previously by O'Reilly et al. (2014) and Van Landeghem et al. (2015) and been interpreted as carbonate mounds. This study identified a further two mounds which exhibit a roughly circular morphology and have an approximate diameter of $60 \mathrm{~m}$ (Fig. 6). They protrude 8 and $16 \mathrm{~m}$ respectively from the seabed and have a higher backscatter than the surrounding seafloor. Based on their morphological similarity and proximity with the carbonate mounds identified Van Landeghem et al. (2015), we infer that these two mounds are probably also carbonate mounds (MDAC) formed due to prolonged seepage of methane gas from the seafloor. However, geochemical sampling and ROV image grabs would be required to ground-truth their association with gas seepage.

Lambay Deep

The Lambay Deep itself is a pronounced bathymetric low on the seabed, forming a linear trough-like feature broadly oriented NW-SE that is approximately $11 \mathrm{~km}$ long. The Deep is $135 \mathrm{mbsl}$ at its deepest point and is generally $50 \mathrm{~m}$ deeper than the surrounding seabed (Fig. 7). The northern extent of the Lambay Deep is bound by an area of exposed bedrock, identified by its rugged seafloor morphology and high backscatter. At its southern extent, the Deep is bound by a sediment wave field. Located near the centre of the Deep is a prominent mound forming a bathymetric high with a clear backscatter contrast to the surrounding seabed (Fig. 7).

The sparker data acquired over the Lambay Deep cover the area above the mound, where we observe an acoustically transparent $24 \mathrm{~m}$ thick unit, above an enhanced reflection (LD-1, Fig. 8). The western flank exhibits acoustic turbidity. These acoustic anomalies are possibly attributed to the accumulation of shallow gas beneath the mound, which was earlier described by Croker et al. (2005) as the Lambay Deep Mud Diapir (LDMD). To the east of the LDMD, low-amplitude parallel to sub-parallel reflections 
characterise the sedimentary sequence. The acoustic turbidity zone is imaged on a second representative seismic line across the Deep, and further illustrates an upper acoustic unit displaying an almost transparent seismic signature with faint, horizontal, parallel laminations overlying an enhanced reflection in the centre of the deep (LD-2, Fig. 8). The enhanced reflections imaged in both these sparker lines could be possibly attributed to the sharp acoustic impedance contrast between the underlying gas charged sediments and the overlying lithology. Hence, the enhanced reflections are interpreted as top of shallow gas accumulation. The flanks exhibit a more complex stratigraphy with chaotic acoustic units bounded by moderate to strong internal reflectors. The acoustic turbid zones are possibly caused due to scattering of acoustic energy by gas which is finely disseminated within impervious clay-rich sediments.

292 The sedimentary strata on either side of the LDMD exhibit onlapping structures, which is typical at mud diapir locations (Fig. 8). Onlapping stratigraphy on either side of the LDMD suggest uplifting due to the structure (Fig. 8).

\section{Western Irish Sea Mud Belt}

As described earlier, the enhanced reflection is interpreted as the top of the shallow gas accumulation in the WISMB, which lies between 8 and 18 mbsf and extends across an area of approximately $90 \mathrm{~km}^{2}$ (Fig. 9). The accumulation has an inverted bowl topography with the rims climbing down towards its edges, and an enhanced reflection marks the top (Fig. 10). The upper layers in the gas-charged zone are lenticular, and characterized by an acoustically turbid zone, while exhibiting a sharp contrast to the surrounding sediments (Fig. 10). Sub-bottom acoustic anomalies related to shallow gas accumulation in this area of the WISMB and details on the shallow seismic stratigraphy have previously been documented by Coughlan et al. (2019).

Circular to sub-circular crater like features were identified on bathymetry data, which were interpreted as pockmarks which are direct indicators of fluid seepage at the seafloor. A total of seventeen pockmarks (P1-17) were identified using the slope tool in ArcGIS to highlight slope changes along pockmark walls. All pockmarks in this study (with the exception of P12) were found in water depths greater than $40 \mathrm{~m}$ (Fig. 9). Information on calculated dimensions and morphology for each pockmark is presented in the supplementary material (S1). Two separate morphologies were identified: pockmarks with central mounds within them and pockmarks without any central mounds. 
P1, P2 and P3 are clustered with a distance of $355 \mathrm{~m}$ between P1 and P2 and a further $420 \mathrm{~m}$ between P2 and P3 in a northerly direction. Other pockmarks along this trend are more widely spaced. Pockmarks $\mathrm{P} 1$ to $\mathrm{P} 12$ are sub-circular in shape, although P5-P8 are more elongate. The alignments of the long-axis of the elongate pockmarks are in different orientations suggesting no influence of bottom currents on the morphological evolution of the pockmarks. Relief relative to the seabed varies between $0.6 \mathrm{~m}(\mathrm{P} 3)$ and $1.6 \mathrm{~m}$ (P10) with pockmarks becoming generally larger and deeper to the northwest. P12 is a typical giant irregular pockmark, as documented in the UK North Sea (Cole et al., 2000). It is elliptical in planview, and at least 5 times larger than any of the other pockmarks in this group, the short and long axis being c. $500 \mathrm{~m}$ and $1000 \mathrm{~m}$.

Most pockmarks in this study are between 74 and $153 \mathrm{~m}$ wide with P7, P10 and P11 being 171 to $268 \mathrm{~m}$ wide. P4 and the larger P10 and P11 pockmarks contain small mounds at their centre being $0.1 \mathrm{~m}, 0.2 \mathrm{~m}$ and $0.4 \mathrm{~m}$ high respectively (Fig. 11). P14, P15, P16 and P17 are all circular with a depth typically of 0.4 $\mathrm{m}$ to $1 \mathrm{~m}$ relative to the seabed. $\mathrm{P} 15$ also has a mound about $0.1 \mathrm{~m}$ in height at its centre. Maximum diameters vary from $54.5 \mathrm{~m}$ to $90 \mathrm{~m}$ across with the larger-diameter pockmarks tending to be deeper.

\section{$\underline{\text { Queenie Corner }}$}

Analysis of the MBES data from the Queenie Corner MCZ suggests largely the same flat topography as seen in the WISMB with notable mound structures. The mounds occur in isolation as well as part of a linear chain, which is approximately $2 \mathrm{~km}$ in length (Fig. 12). They exhibit a maximum relief of $1 \mathrm{~m}$ compared to the regular seabed (Fig. 12). Backscatter data from these mounds also indicate higher reflectance compared to the surrounding sediments (Fig. 12).

A single Pinger line from the Queenie Corner site revealed acoustic turbidity, indicating shallow gas, at its western end, coinciding with the mounds observed on MBES data (Fig. 12 and 14). The top of the acoustic turbidity occurs within $1 \mathrm{~m}$ of the seabed with clear evidence for gas chimneys reaching the seabed rooted from the acoustic turbid zone. The gas chimneys emanating from the acoustic turbid zone precisely underlie the mounds observed on the MBES data. Further east, we observe a sharp boundary of the turbidity zone which is interpreted as the gas front (Fig. 13B). 


\section{DISCUSSION}

\section{Revised geological model with inferences on gas origin and controls on fluid migration}

Structural lineaments (i.e. faults) and the properties of Quaternary sediments in the Irish Sea play a significant role in fluid migration from deep seated hydrocarbon source rocks to the shallow subseafloor stratigraphic layers, and eventually in subsequent seepage at the seafloor. In this section we discuss an individual, revised geological model for the CFZ and WISMB to elucidate the potential origins for hydrocarbon fluids in both areas and the pathways that would allow for the migration of such fluids to the sub-seabed and seafloor. This is not to suggest that there is no biogenic component to any shallow gas in these areas. The data presented demonstrates that a thermogenic source cannot be excluded, and it is accepted that mixing of sources can occur.

\section{Codling Fault Zone (incl. Lambay Deep)}

Gas-prone source rocks have been proven throughout the Irish Sea with the most prolific being the gasprone Pennine Coal Measures Group and the oil-prone Bowland Shale Formation, both of Carboniferous age (Pharaoh et al., 2016). Within the study area, the Pennine Coal Measures Group has been proven in the 33/22-1 borehole on the southern margin of the Kish Bank Basin where 17 metres of coal were encountered with associated methane gas being detected within these coal horizons (Thomas, 1978). These coal-bearing horizons are interpreted throughout the Kish Bank Basin and are observed as the high-amplitude reflectors visible beneath the Base-Permian Unconformity (Fig. 3). Analysis of vitrinite reflectance data at the 33/22-1 borehole indicates these gas-prone source rocks have reached the pressure and temperature conditions to generate gas at present-day, suggesting that these same horizons at deeper, down-dip positions have generated hydrocarbons (Thomas, 1978). The Bowland Shale Formation has not been encountered in the 33/22-1 borehole, where the Pennine Coal Measures Group sits unconformably upon Lower Palaeozoic metasediments, although erosional outliers may be preserved elsewhere in the study area.

In addition to the presence of gas-prone source rocks, several indicators of an active petroleum system have been encountered in the vicinity of the Kish Bank Basin, in the form of both liquid and gaseous hydrocarbons. Both the previously mentioned 33/22-1 borehole and the 33/17-1 borehole on the eastern margin of the Kish Bank Basin encountered residual oil, the former in Carboniferous sandstones 
and the latter in Triassic sandstones (Charterhouse, 1986; Thomas, 1978). The 33/22-1 borehole reported tentative oil-staining in Lower Pleistocene sands which may indicate the remigration of liquid hydrocarbons from within the bedrock to these shallow, unconsolidated sediments. Previous authors have also presented a proprietary seep dataset which shows the location of present-day oil seeps, with a strong correlation between the location of seeps and distribution of both large faults and where sourcerocks sub-crop at the seabed (e.g. Anderson, 2013; Dunford et al., 2001).

Remigration of hydrocarbons from the bedrock to the shallow seabed can be facilitated by recent tectonic activity, which creates fluid conduits in the form of faults, which either breach existing hydrocarbon accumulations at depth or allow hydrocarbons to migrate directly from source rocks to seabed sediments (Anka et al., 2012; Corcoran and Doré, 2002). In the study area, the Codling Fault Zone is the most recent tectonic feature, being a NNW-SSE trending strike-slip fault and offshore extension of the Newry and Camlough Faults of Northern Ireland (Fig. 1). Kilometre-scale dextral motion on the fault has been recorded by several previous studies (e.g. Dunford et al., 2001) with the most recent research indicating displacement of 8.7 kilometres, incorporating up to 2 kilometres of normal movement on the basin-bounding fault along the northern margin of the Kish Bank Basin (Anderson, 2013). The timing of this fault activity is poorly constrained due to the attenuated Cenozoic section preserved in the study area but has been inferred to have a component of both Paleocene and Oligocene movement (Anderson, 2013; Dunford et al., 2001).

Several observations from 2D multichannel seismic data recorded in this study correlate spatially with the location of the Codling Fault Zone. Within the confines of the Kish Bank Basin, amplitude brightening is observed above the fault zone within the Quaternary units, with a sharp western boundary directly above the trend of one of main fault splays and a more diffuse contact to the east (Fig. 3). Additionally, reverse polarity anomalies are observed in the Cenozoic section directly above the fault zone. While none of the available boreholes penetrate these anomalies, correlation with those seismic intervals along-strike indicate these sediments consist of poorly consolidated sandstones interbedded with thin layers of mudstone (Charterhouse, 1986; Thomas, 1978). These anomalies may represent local charging of these sands with re-migrated gaseous hydrocarbons which have migrated up the main fault plane of the Codling Fault Zone (e.g. Løseth et al., 2009).Other authors have presented proprietary singlechannel seismic data from this area which supports this interpretation, such as reverse-polarity anomalies and flat spots reported by Dunford et al., (2001). However, these anomalies will remain a speculative interpretation until ground truthing is done by geochemical sampling. 
Evidence for shallow gas is also observed in Quaternary sediments (i.e. the PF and SSF) from shallow, sub-bottom acoustic data in the Lambay Deep causing enhanced reflection (Fig. 8). The PF has also been observed to be gas-bearing in the CFZ (Van Landeghem et al., 2015). Whilst we infer a thermogenic origin for the gas/fluids in this area, a biogenic component cannot be discounted. Isotope analysis of MDAC at the CFZ SAC by O'Reilly et al. (2014) suggests possible mixing of biogenic and thermogenic sourced gas. Based on the present data, it is not possible to estimate the timescales for the migration of these fluids. The Croker Carbonate Slab SAC is located 12-15 kms NE of the CFZ SAC area (Fig. 1). Judd et al. (2019) place the formation of MDACs in the Croker Carbonate Slab SAC between 17 ka BP to 5 ka BP, with evidence for present day gas seepage. The MDAC cements the PF, which is inferred as being deposited in a glaciomarine environment between approximately 20 ka and 10 ka BP (Judd et al., 2019). It is also assumed that, prior to the deposition of the PF as the ISIS retreated, gas accumulated beneath the ice sheet (Judd et al., 2019). Gas accumulations below ice-sheets has also been proposed for other locations globally during the Devensian (Crémière et al., 2016; Fichler et al., 2005; Portnov et al., 2016). This spatial correlation of seabed features with the Codling Fault Zone implies that at least a portion of the fluids responsible for their formation will be bedrock-sourced thermogenic gas, with the Codling Fault Zone acting as the main conduit for the migration of hydrocarbon fluids to the shallow subsurface.

Western Irish Sea Mud Belt (including Queenie Corner)

Shallow gas accumulations have been observed in the MF in the WISMB, acoustically blanking the layers below (Coughlan et al., 2019) (Fig. 10). Similar accumulations of shallow gas in the WISMB have previously been linked with a biogenic origin, given the organic rich nature of the MF sediments (Yuan et al., 1992). Stable isotope data in Woods et al. (2019) presents evidence for methane seeps in the WISMB during the Mid Holocene age (post $8.2 \mathrm{ka}$ ). Considering the Holocene age of the MF and the estimated volume of gas present (Supplementary Material; S2), it is difficult to envision a solely biogenic source. This study has provided credible evidence of shallow gas accumulation directly above a Permo-Triassic infilled basin with its boundaries defined by the graben-bounding faults (Fig. 3 and Fig. 14). These faults, which were reactivated during the Cenozoic and are observed offsetting the Base-Cenozoic Unconformity, would provide pathways for fluid flow from the Carboniferous source rocks below (Fig. 14). The gas is seen to be hosted in the PF, below the base of the MF (Fig. 10). This suggests upward fluid migration through the underlying CF (glacial outwash sediments) and UT member (subglacial till). Whilst the UT in the Irish Sea is often over-consolidated, it is highly heterogeneous comprising a range of sediment classes that would facilitate fluid migration through it (Fig. 14) (Coughlan et al., 2019; Van 
Landeghem et al., 2015). The top of the shallow gas is typically within 10-12 m of the seabed-surface and has a sharp boundary with the surrounding non-gas bearing sediments (Fig. 10). Pockmarks P14, P15, P16 and P17 were found to coincide with the lateral extent of underlying shallow gas accumulation, previously identified by Coughlan et al. (2019) (Fig. 9 and Fig. 15). Episodic or continuous migration of this shallow gas accumulation to the seafloor would allow for fluid seepage at the seafloor, and the formation of features such as mounds and pockmarks, which will be discussed in more detail in the next section. Pockmarks occurring outside this accumulation of shallow gas form a strong, linear trend coincident with the prognosed extension of the Codling Fault Zone (Fig. 15), implying that fluid migrating from deeper source rocks along the main fault of CFZ possibly seep out from these pockmarks.

\section{Formation mechanisms of seep-related seafloor features}

We can classify seep-related seafloor morphological features observed in this study into two different types: mounds and pockmarks (Fig. 15). Mounds can be further classified into mounds formed from MDACs and mounds formed due to mud-diapirism. Mounds described here in association with the CFZ have collectively been described extensively in the literature as carbonate mounds formed from MDACs (Judd et al., 2019; O’Reilly et al., 2014; Van Landeghem et al., 2015). Alternatively, the mound located within Lambay Deep was described by Croker et al. (2005) as the Lambay Deep Mud Diapir (LDMD). Judd and Hovland (2007) defined a mud diapir as a sediment structure that has risen through a sediment sequence due to upward migrating fluids, piercing or deforming younger sediments. Mud diapirs can be recognised on seismic profiles as an acoustically amorphous piercement structure, as documented in the East China Sea (Xing et al., 2016), SW Taiwan (Chen et al., 2014), and the Mediterranean Ridge (Camerlenghi et al., 1992). In this section we focus on the formation mechanisms of the remaining seabed features in the WISMB, which are poorly understood in an Irish Sea context.

The pockmarks identified in this study are concentrated in the western part of the WISMB (Fig. 15). Within this set of pockmarks (P1-P17) there are two different morphologies: pockmarks with a central mound and pockmarks without a central mound. All the pockmarks are located in an area of sandy-mud to muddy-sand according to the British Geological Survey DigSBS250 database (Fig. 15). This differentiates them from pockmarks previously documented by Yuan et al. (1992), which were located in areas dominated by mud class sediments and were related to a zone of "acoustically turbid sediments" (ATZ) (Fig. 15). Yuan et al. (1992) offers no explanation for the mechanism for their formation, although 
Croker et al. (2005) does highlight the requirement of clay- to silt-grade substrate for the formation of pockmarks. The fluids escaping from these pockmarks could either be biogenic- or thermogenic-sourced or of mixed origin. We further suggest that pore-water escape from the shallow glacimarine deposits could have also led to the formation of pockmarks, as suggested in other glacimarine settings (Harrington, 1985; Roy et al., 2019), however, pore-water escape would not support the formation of mounds within pockmarks.

Low-relief seabed mounds are found in Queenie Corner in the eastern part of the WISMB, which is characterised by sandy-mud seafloor sediments (Fig. 15). Mounds mapped by Croker et al. (2005) occur in areas of mud and sandy mud (Fig. 15). The near surface sediments in the WISMB are often underconsolidated, and so likely to be highly permeable (Coughlan et al., 2019; Mellet et al., 2015), which is unsuitable for the mechanism of formation proposed by Croker et al. (2005). In this study, described mounds and pockmarks are located in distinct areas and separated from each other.

The distribution of these seep-related seafloor morphological features varies over differing seafloor sediment types, which indicates differing formation mechanisms. Based on previous studies (Brothers et al., 2011; Crémière et al., 2018; Hammer et al., 2009; Hovland, 2002; Loher et al., 2018) and observations made in this study, we discuss two conceptual models for:

(i) The formation of central mounds within pockmarks in muddy sediment areas with a sandcomponent, and;

(ii) The formation of seabed mounds in muddy sediments, leading to the formation of collapsed pockmarks.

The formation of central mounds within pockmarks in sediments with a sand component

Initially fluid seepage at a relatively flat seafloor facilitates the development of microbial mats and an initial MDAC crust, which reduces the seepage rate at that location (Fig. 16A; Stage 1). Over time, this MDAC crust develops further, forming a consolidated seal at the seafloor (Fig. 16A; Stage 2). A combination of seepage of fluids from, and bottom currents at, the seafloor around the mounds preferentially erodes the surrounding un-cemented seafloor sediments, partially exposing the MDAC crust (Fig. 16A; Stage 3). Further seepage of fluids around the perimeter of the carbonate crust along with reworking and winnowing of sediments finally exposes the mound completely, which resembles a 
mound at the centre of a pockmark (Fig. 16A; Stage 4). This is in agreement with the formation mechanism of carbonate mounds within pockmarks on a relatively flat seabed whereby a combination of fluid seepage and bottom currents erode the surrounding un-cemented seafloor sediments, partially exposing the mound in the centre of the pockmarks as has been suggested by Crémière et al. (2018). Similar carbonate crusts have been observed within pockmarks in the Harstad Basin in the Barents Sea (Crémière et al., 2018) and offshore Norway (Hovland et al., 2010), where several satellite pockmarks surrounding the 'mother pockmark' have been documented with a carbonate mound in the centre.

\section{The formation of seabed mounds, leading to pockmarks in muddy sediments}

Initially, prolonged seepage of methane gas at the seafloor leads to the formation of thin fragments of MDAC, followed by cementation of these thin MDAC fragments just beneath the seabed (Fig. 16B; Stage 1). The thin MDAC crust beneath the seabed acts as an impermeable seal at the seabed sediment-water interface and redirects fluid seepage around the MDAC crust perimeter (Fig. 16B; Stage 2). Gas starts to accumulate and build up pore-pressure beneath the crust, while also increasing the pore-volume. The build-up of pore pressure and increase of pore volume within the unconsolidated sediments underlying the MDAC crust is facilitated by the combined effect of upward fluid migration and sealing capacities of mud-rich sediments and the MDAC crust. The sealing effect of the MDAC crust, along with the buoyant force of the upward migrating gas and increase in pore-volume, results in the bulging outward of the unconsolidated sediments and the MDAC crust (Fig. 16B; Stage 3). At this point, the MDAC crust has been modified to a carbonate mound due to the outward bulging of the sediments underneath, such as the mounds at Queenie Corner (Fig. 13). The gradual increase in the buoyant force of the gas further leads to the formation of fractures within the deformed MDAC mound, to the point when the MDAC mound ruptures and collapses under its own weight after the underlying pressurised gas has dissipated (Fig. 16B; Stage 4). The collapsed mound resembles a crater-like depression like a pockmark. A single grab sample taken from the area of seafloor mounds in the southwestern section of Queenie Corner revealed cemented muds, with a strong odour, which would suggest hardened substrates caused by oxidation of methane forming carbonate precipitates (Supplementary Material; S3). However, this hypothesis assumes that the initial MDAC crust formation is thin enough to be deformed by the increase in pore pressure and volume due to the upward migrating fluids. 


\section{Data interpretation and geological model limitations}

The identification, characterisation and assessment of geohazards such as shallow gas, fluid flow and seepage involves a multidisciplinary approach utilising a range of site investigation techniques (Cevatoglu et al., 2015; Clare et al., 2017; Vanneste et al., 2014). This study aims to integrate multi-scale geophysical datasets in order to develop a geological framework to study potential fluid migration pathways from deeper stratigraphy or source rocks to shallow gas accumulations, and thereafter seepage at seafloor in the Irish Sea. Characterising and describing shallow gas acoustic features on shallow seismic data in particular depends on the acquisition system and frequencies used (Tóth et al., 2014). The shallow sub-bottom data used to characterise shallow sub-seabed features were gathered as part of regional surveys, without the express intention of studying shallow gas and fluid flow. The systems used to gather shallow sub-bottom data (i.e. sparker and pinger) transmit a signal within a frequency range of $0.5-4 \mathrm{kHz}$, which can be attenuated through scattering by fluid bubbles in gas charged sediments, the result of which is acoustic turbidity and blanking (Tóth et al., 2014). Both these phenomena are recognised in this study (Fig. 10) and are common at depth in such areas of mud to sandy mud on single-channel datasets (e.g. Laier and Jensen, 2007). As a result, only the top of the gas front is identified on shallow sub-bottom data, and there is ambiguity with regards to the depth of shallow gas and details of the underlying geology. However, low-frequency 2D-multichannel seismic provides information on underlying bedrock geology and tectonics. Ultimately, some studies show amplitude versus offset (AVO) analysis on 2D-multichannel seismic data to further affirm the presence of gas in the sediments (e.g. Kim et al., 2020)

At the seafloor, geomorphological features synonymous with fluid migration and seepage can be mapped using multibeam echosounder (e.g. Roelofse et al., 2020). In this study pockmarks have been identified, characterised and discussed within the context of fluid migration and seepage. However, there is a current lack of geochemical data from these pockmarks to ascertain the nature of fluids seeping from them. Analysis of cores taken in the vicinity of the pockmarks in the WISMB and the LDMD discussed here proved inconclusive in terms of determining the composition of sub-surface fluids due to a lack of depth penetration (O'Reilly, S. pers. Comms.). As this study has identified several areas within the northern Irish Sea where there is compelling evidence for the presence of gas in the shallow subsurface, we anticipate future research cruises will acquire sediment and pore-water samples to confirm the nature of origin or fluids seeping from these locations. 


\section{Implications of shallow gas and fluid seepage}

The presence of gas accumulations in shallow sub-surface sediments can have engineering implications for the construction of offshore infrastructure and is considered a geohazard within the hydrocarbon and maritime industry (Evans, 2011; Hovland et al., 2002; Sun et al., 2017) as well as for renewable energy developments (Society for Underwater Technology, 2005). When gas occurs in solution in the pore-water, or free gas-filled voids between sediment grains, it can affect the compressibility of the sediment and negatively influence the engineering properties (Sills and Wheeler, 1992; Sultan et al., 2012). Where fluid seeps to the seafloor, it can impact the ground-conditions by: (i) forming a hard surface (i.e. MDAC), which may be difficult to pile or penetrate, or; (ii) causing changes in seabed bathymetry (e.g. doming or pockmarks), which would create seabed instability. Hence, it is vital to do a marine baseline study of an area of interest before installation of submarine engineering structures. This study, inter alia, has mapped a widespread occurrence of shallow gas throughout the north Irish Sea as well as included previous studies in the area, which overlies a variety of geological and tectonic settings (Fig. 1 and 15). More research is required to better understand the migration of fluids along proposed fault-routes, their sealing versus leaking capabilities, and the true nature and timing of the seeping fluids. At the very least, it is possible to anticipate where certain shallow gas and fluid escape structures may be encountered based on regional geology and mitigating site investigation techniques planned accordingly.

587

Studies have shown that MDAC harbours different benthic communities to surrounding sediments in the Irish Sea: whether this is due to the formation of complex three-dimensional reef-like structures in otherwise fairly homogeneous sedimentary habitats, thereby allowing colonisation by taxa common on hard rocky substrates, or due to the unique characteristics of MDAC which are as yet unclear (Judd et al., 2019; Noble-James et al., 2020). Pockmarks have been shown to harbour exclusive fauna in the North Sea (Webb et al., 2009), characterised by species with endosymbiotic sulphur-oxidising bacteria, as well as the structures providing shelter for specific fish species (Dando, 2001). (Dando, 2010) reviewed 62 shallow-water hydrothermal vent and cold seep sites and found that obligate species are rare at such sites, however higher species diversity was often found in the immediate vicinity of seeps often due to the heterogeneity of the bathymetry, compared with surrounding more homogeneous areas. As yet, the pockmarks and seabed doming in this study have not had targeted biological sampling, but at 
Queenie Corner cemented sediment was retrieved by Day-grab from one seabed dome area with faunal excavation of the cemented sediment by bivalves and gastropods (Supplementary Material; S3). Whether the fauna in such structures is unique compared to surrounding sedimentary areas would require further investigation; however, substrata-boring fauna could be viewed as a functionally significant component of the local ecosystem (Noble-James et al., 2020). An understanding of this, coupled with accurate mapping of the extent and potential ecological connectivity of such features throughout the Irish Sea, is required to underpin effective management of these habitats.

\section{CONCLUSIONS AND FUTURE WORK}

High-resolution geophysical datasets from the Irish Sea reveal sub-seabed shallow gas accumulations in Quaternary sediments and a range of seafloor expressions of fluid seepage. Based on the integrated geophysical investigation of seafloor geomorphologies, shallow sub-surface sediments and deeper geological and tectonic features, this study generated a geological framework from which the following can be made summarised.

In both the Codling Fault Zone and Western Irish Sea Mud Belt, there is compelling evidence linking shallow gas accumulation within Quaternary sediments with major structural lineaments (i.e. faults) in the bedrock geology. These faults can act as pathways for hydrocarbon fluids to migrate from deeply seated source rocks to shallow stratigraphic layers. This supports earlier geochemical studies which found a thermogenic component to the shallow gas and seafloor seepage features in both these areas.

In the Western Irish Sea Mud Belt, both pockmarks and seabed mounds were recorded in areas of mud with a varying sand component. Pockmarks display two morphologies consisting of regular, circular types and pockmarks with a central mound, typically less than $0.5 \mathrm{~m}$ in relief. Pockmark centres often exhibit high backscatter reflectance values suggesting some degree of sediment consolidation due to the formation of MDAC. Mounds are typically $1 \mathrm{~m}$ in height above the regular seabed and are associated with gas chimneys rooted to an underlying shallow gas accumulation. These mounds, and surrounding seabed, exhibit high back backscatter reflectance values, again, suggesting the formation of MDAC. This is supported by a grab sample from a mound containing cemented, MDAC-like material. 
We propose two mechanisms for the formation of pockmarks; one in muddy seafloor settings with a sand component, which accounted for the formation of a central mound, and one for the formation of thin MDAC mounds as pre-cursors to pockmarks in muddy seafloor settings.

Based on our findings, we make the following concluding statements and recommendations for future work:

- The revised geological models for the Codling Fault Zone and Western Irish Sea Mud Belt allow for a better understanding of the role of existing and re-activated faults as a potential pathway for fluid (e.g. gas) migration from kilometre-scale depth to the shallow sub-seabed. In future, this will help quantify the contribution of thermogenic-sourced gas to ongoing shallow subseabed gas accumulation and seafloor seepage in these areas. Geochemical analysis of targeted seabed seepage and shallow gas accumulation locations from the Western Irish Sea Mud Belt is required to constrain the origin of shallow gas definitively and is a proposed area of further work.

- To validate the model linking the creation of MDAC to pockmark formation, repeat survey data over the mounds at Queenie Corner is required to record their evolution over time.

- The presence of shallow gas accumulations in the Western Irish Sea Mud Belt, along with gas chimneys and mounds, suggests that fluid seepage at the seafloor is an on-going process. This has significant implications for seabed infrastructure development and seabed ecological and conservation efforts. Based on the results of this study and models presented, our understanding of the geological controls on fluid migration and seafloor seepage is greatly improved, making it increasingly possible to predict the extent of shallow gas and location of certain gas seepage structures in the Irish Sea. Future data collection surveys (e.g. INFOMAR) will further improve this understanding.

- To better constrain gas content and extent of gas front in areas of acoustic blanking, we recommend the acquisition of multichannel seismic data and the application of AVO analysis.

- Ground-truthing and further geotechnical analysis of Quaternary sediments is required to better understand how fluids migrate through, and are hosted in, these sediments. 


\section{Acknowledgements}

- Biological data available from the Western Irish Sea Mud Belt pockmarks and mounds are limited in determining the range of biodiversity at these sites at present. Epibenthic surveys consisting of drop-frame or towed camera platforms or ship-based grab sampling are typically unable to spatially target and sample chemoautotrophic communities, so it is recommended that ROV techniques are used for such purposes.

This research is funded in part by a research grant from Science Foundation Ireland (SFI) under Grant Number 13/RC/2092 and is co-funded under the European Regional Development Fund, and by the Petroleum Infrastructure Programme (PIP) and its member companies. SR is funded by the Irish Research Council Government of Ireland Postdoctoral Fellow Award (GOIPD/2018/17). The authors would like to thank the Petroleum Affairs Division (PAD) of the Department of Communications, Climate Action and Environment (DCCAE), Ireland, for providing access to released borehole, seismic and potential field datasets. The authors would also like to thank Schlumberger for providing academic licenses of Petrel to University College Dublin. We are grateful to IHS Markit for providing the academic licence for the KINGDOM software package to iCRAG. This paper contains Irish Public Sector Data (INFOMAR) licensed under a Creative Commons Attribution 4.0 International (CC BY 4.0) licence. The authors acknowledge Dr. Matthew Service and Rory O'Loughlin (both Agri-Food and Biosciences Institute, Northern Ireland) for releasing the MBES data for Queenie Corner, and for support during the AFBI surveys. The pinger line shown was acquired as part of NERC project NE/H02431/1. The authors acknowledge Rosie Jebb (GSI) and Andy Trafford (UCD) for assistance processing MBES and sub-bottom profile data respectively. The authors also acknowledge the crew and scientists onboard all surveys listed for their work, co-operation and skill in collecting the data. The authors would like to thank 3 reviewers for their feedback and comments which greatly improved this manuscript.

\section{References}

Anderson, H., 2013. The origin and nature of Cenozoic faulting in north-east Ireland and the Irish Sea. University College Dublin.

Andreassen, K., Nilssen, E.G., Ødegaard, C.M., 2007. Analysis of shallow gas and fluid migration within the Plio-Pleistocene sedimentary succession of the SW Barents Sea continental margin using 3D seismic data. Geo-Marine Lett. 27, 155-171. https://doi.org/10.1007/s00367-007-0071-5

Anka, Z., Berndt, C., Gay, A., 2012. Hydrocarbon leakage through focused fluid flow systems in continental margins. Mar. Geol. 332-334, 1-3. 
https://doi.org/https://doi.org/10.1016/j.margeo.2012.10.012

Brothers, L.L., Kelley, J.T., Belknap, D.F., Barnhardt, W.A., Andrews, B.D., Maynard, M.L., 2011. More than a century of bathymetric observations and present-day shallow sediment characterization in Belfast Bay, Maine, USA: implications for pockmark field longevity. Geo-Marine Lett. 31, 237-248. https://doi.org/10.1007/s00367-011-0228-0

Bunce, J., 2018. The history of exploration and development of the Liverpool Bay fields and the East Irish Sea Basin. Hist. Eur. Oil Gas Ind. https://doi.org/10.1144/SP465.6

Camerlenghi, A., Cita, M.B., Hieke, W., Ricchiuto, T., 1992. Geological evidence for mud diapirism on the Mediterranean Ridge accretionary complex. Earth Planet. Sci. Lett. 109, 493-504. https://doi.org/https://doi.org/10.1016/0012-821X(92)90109-9

Cevatoglu, M., Bull, J.M., Vardy, M.E., Gernon, T.M., Wright, I.C., Long, D., 2015. Gas migration pathways, controlling mechanisms and changes in sediment acoustic properties observed in a controlled sub-seabed CO2 release experiment. Int. J. Greenh. Gas Control 38, 26-43. https://doi.org/https://doi.org/10.1016/j.ijggc.2015.03.005

Charterhouse, 1986. Well 33/17-1 Final Geological Report.

Chen, S.-C., Hsu, S.-K., Wang, Y., Chung, S.-H., Chen, P.-C., Tsai, C.-H., Liu, C.-S., Lin, H.-S., Lee, Y.-W., 2014. Distribution and characters of the mud diapirs and mud volcanoes off southwest Taiwan. J. Asian Earth Sci. 92, 201-214. https://doi.org/https://doi.org/10.1016/j.jseaes.2013.10.009

Clare, M.A., Vardy, M.E., Cartigny, M.J.B., Talling, P.J., Himsworth, M.D., Dix, J.K., Harris, J.M., Whitehouse, R.J.S., Belal, M., 2017. Direct monitoring of active geohazards: Emerging geophysical tools for deep-water assessments. Near Surf. Geophys. 15, 427-444. https://doi.org/10.3997/1873-0604.2017033

Clements, A., Service, M., 2016. Alternative Marine Conservation Zones in Irish Sea mud habitat: Assessment of habitat extent and condition at "Queenie corner" and assessment of fishing activity at potential MCZ sites. Report to Seafish Northern Ireland Advisory Committee.

Cole, D., Stewart, S.A., Cartwright, J.A., 2000. Giant irregular pockmark craters in the Palaeogene of the Outer Moray Firth Basin, UK North Sea. Mar. Pet. Geol. 17, 563-577. https://doi.org/https://doi.org/10.1016/S0264-8172(00)00013-1

Corcoran, D. V, Doré, A.G., 2002. Depressurization of hydrocarbon-bearing reservoirs in exhumed basin settings: evidence from Atlantic margin and borderland basins. Geol. Soc. London, Spec. Publ. 196, 457 LP - 483. https://doi.org/10.1144/GSL.SP.2002.196.01.25

Coughlan, M., Wheeler, A.J., Dorschel, B., Long, M., Doherty, P., Mörz, T., 2019. Stratigraphic model of the Quaternary sediments of the Western Irish Sea Mud Belt from core, geotechnical and acoustic data. Geo-Marine Lett. 39, 223-237.

Crémière, A., Chand, S., Sahy, D., Thorsnes, T., Martma, T., Noble, S.R., Pedersen, J.H., Brunstad, H., Lepland, A., 2018. Structural controls on seepage of thermogenic and microbial methane since the last glacial maximum in the Harstad Basin, southwest Barents Sea. Mar. Pet. Geol. 98, 569-581. https://doi.org/https://doi.org/10.1016/j.marpetgeo.2018.07.010

Crémière, A., Lepland, A., Chand, S., Sahy, D., Condon, D.J., Noble, S.R., Martma, T., Thorsnes, T., Sauer, S., Brunstad, H., 2016. Timescales of methane seepage on the Norwegian margin following collapse of the Scandinavian Ice Sheet. Nat. Commun. 7, 11509. https://doi.org/10.1038/ncomms11509

Croker, P.F., Kozachenko, M., Wheeler, A.J., 2005. Gas-Related Seabed Structures in the Western Irish Sea (IRL-SEA6).

Dando, P.R., 2010. Biological communities at marine shallow-water vent and seep sites, in: Kiel, S. (Ed.), Vent and Seep Biota: Aspects from Microbes to Ecosystems. Springer Netherlands, Dordrecht, pp. 333-378. https://doi.org/10.1007/978-90-481-9572-5_11

Dando, P.R., 2001. A review of pockmarks in the UK part of the North Sea, with particular respect to their biology. Strategic Environmental Assessment - SEA2. Technical Report 001 - Pockmarks. 
Dondurur, D., Çifçi, G., Drahor, M.G., Coşkun, S., 2011. Acoustic evidence of shallow gas accumulations and active pockmarks in the İzmir Gulf, Aegean sea. Mar. Pet. Geol. 28, 1505-1516. https://doi.org/10.1016/j.marpetgeo.2011.05.001

Dunford, G.M., Dancer, P.N., Long, K.D., 2001. Hydrocarbon potential of the Kish Bank Basin: integration within a regional model for the Greater Irish Sea Basin. Geol. Soc. London, Spec. Publ. 188, 135 LP 154. https://doi.org/10.1144/GSL.SP.2001.188.01.07

Ergün, M., Dondurur, D., Çifçi, G., 2002. Acoustic evidence for shallow gas accumulations in the sediments of the Eastern Black Sea. Terra Nov. 14, 313-320. https://doi.org/10.1046/j.13653121.2002.00434.x

Evans, T.G., 2011. A systematic approach to offshore engineering for multiple-project developments in geohazardous areas, in: Frontiers in Offshore Geotechnics II - Proceedings of the 2nd International Symposium on Frontiers in Offshore Geotechnics. pp. 3-32.

Fichler, C., Henriksen, S., Rueslaatten, H., Hovland, M., 2005. North Sea Quaternary morphology from seismic and magnetic data: indications for gas hydrates during glaciation? Pet. Geosci. 11, 331 LP 337. https://doi.org/10.1144/1354-079304-635

Floodpage, J., Newman, P., White, J., 2001. Hydrocarbon prospectivity in the Irish Sea area: insights from recent exploration of the Central Irish Sea, Peel and Solway basins. Geol. Soc. London, Spec. Publ. 188, 107 LP - 134. https://doi.org/10.1144/GSL.SP.2001.188.01.06

Games, K.P., 2001. Evidence of shallow gas above the Connemara oil accumulation, Block 26/28, Porcupine Basin, in: Haughton, P.W., Corcoran, D. V (Eds.), The Petroleum Exploration of Ireland's Offshore Basins. The Geological Society of London, Special Publications, London, pp. 361-373. https://doi.org/10.1144/GSL.SP.2001.188.01.21

Hammer, $\varnothing$., Webb, K.E., Depreiter, D., 2009. Numerical simulation of upwelling currents in pockmarks, and data from the Inner Oslofjord, Norway. Geo-Marine Lett. 29, 269-275. https://doi.org/10.1007/s00367-009-0140-z

Harrington, P.K., 1985. Formation of pockmarks by pore-water escape. Geo-Marine Lett. 5, 193-197. https://doi.org/10.1007/BF02281638

Hovland, M., 2002. On the self-sealing nature of marine seeps. Cont. Shelf Res. 22, 2387-2394. https://doi.org/https://doi.org/10.1016/S0278-4343(02)00063-8

Hovland, M., Curzi, P. V, 1989. Gas seepage and assumed mud diapirism in the Italian central Adriatic Sea. Mar. Pet. Geol. 6, 161-169. https://doi.org/https://doi.org/10.1016/0264-8172(89)90019-6

Hovland, M., Gardner, J. V, Judd, A.G., 2002. The significance of pockmarks to understanding fluid flow processes and geohazards. Geofluids 2, 127-136. https://doi.org/10.1046/j.14688123.2002.00028.x

Hovland, M., Heggland, R., De Vries, M.H., Tjelta, T.I., 2010. Unit-pockmarks and their potential significance for predicting fluid flow. Mar. Pet. Geol. 27, 1190-1199. https://doi.org/10.1016/j.marpetgeo.2010.02.005

Hovland, M., Judd, A.G., 1992. The global production of methane from shallow submarine sources. Cont. Shelf Res. 12, 1231-1238. https://doi.org/10.1016/0278-4343(92)90082-U

Hovland, M., Judd, A.G., 1988. Seabed Pockmarks and Seepages. Graham and Trotman, London.

Jackson, D.I., Jackson, A.A., Evans, D., Wingfield, R.T.R., Barnes, R.P., Arthur, M.J., 1995. United Kingdom offshore regional report: the geology of the Irish Sea. British Geological Survey, London.

Jackson, D.I., Mullholland, P., 1993. Tectonic and stratigraphic aspects of the East Irish Sea Basin and adjacent areas: contrasts in their post-Carboniferous structural styles. Geol. Soc. London, Pet. Geol. Conf. Ser. 4, 791 LP - 808. https://doi.org/10.1144/0040791

Jordan, S.F., O’Reilly, S.S., Praeg, D., Dove, D., Facchin, L., Romeo, R., Szpak, M., Monteys, X., Murphy, B.T., Scott, G., McCarron, S.S., Kelleher, B.P., 2019. Geophysical and geochemical analysis of shallow gas and an associated pockmark field in Bantry Bay, Co. Cork, Ireland. Estuar. Coast. Shelf 
Sci. 225, 106232. https://doi.org/10.1016/j.ecss.2019.05.014

Judd, A., Noble-James, T., Golding, N., Eggett, A., Diesing, M., Clare, D., Silburn, B., Duncan, G., Field, L., Milodowski, A., 2019. The Croker Carbonate Slabs: extensive methane-derived authigenic carbonate in the Irish Sea-nature, origin, longevity and environmental significance. Geo-Marine Lett. https://doi.org/10.1007/s00367-019-00584-0

Judd, A.G., Hovland, M., 2007. Seabed Fluid Flow, the Impact on Geology, Biology, and the Marine Environment. Cambridge University Press.

Judd, A.G., Hovland, M., 1992. The evidence of shallow gas in marine sediments. Cont. Shelf Res. 12, 1081-1095.

Karisiddaiah, S.M., Veerayya, M., 1994. Methane-bearing shallow gas-charged sediments in the eastern Arabian Sea: a probable source for greenhouse gas. Cont. Shelf Res. 14, 1361-1370. https://doi.org/https://doi.org/10.1016/0278-4343(94)90053-1

Kiel, S., 2010. The vent and seep biota, in: Landman, N.H., Harries, P. (Eds.), Topics in Geobiology. Springer, Germany, p. 487.

Kim, Y.-J., Cheong, S., Chun, J.-H., Cukur, D., Kim, S.-P., Kim, J.-K., Kim, B.-Y., 2020. Identification of shallow gas by seismic data and AVO processing: Example from the southwestern continental shelf of the Ulleung Basin, East Sea, Korea. Mar. Pet. Geol. 117, 104346. https://doi.org/https://doi.org/10.1016/j.marpetgeo.2020.104346

Koch, S., Berndt, C., Bialas, J., Haeckel, M., Crutchley, G., Papenberg, C., Klaeschen, D., Greinert, J., 2015. Gas-controlled seafloor doming. Geology 43, 571-574. https://doi.org/10.1130/G36596.1

Laier, T., Jensen, J.B., 2007. Shallow gas depth-contour map of the Skagerrak-western Baltic Sea region. Geo-Marine Lett. 27, 127-141. https://doi.org/10.1007/s00367-007-0066-2

Loher, M., Marcon, Y., Pape, T., Römer, M., Wintersteller, P., dos Santos Ferreira, C., Praeg, D., Torres, M., Sahling, H., Bohrmann, G., 2018. Seafloor sealing, doming, and collapse associated with gas seeps and authigenic carbonate structures at Venere mud volcano, Central Mediterranean. Deep. Res. Part I Oceanogr. Res. Pap. 137, 76-96. https://doi.org/10.1016/j.dsr.2018.04.006

Løseth, H., Gading, M., Wensaas, L., 2009. Hydrocarbon leakage interpreted on seismic data. Mar. Pet. Geol. 26, 1304-1319. https://doi.org/https://doi.org/10.1016/j.marpetgeo.2008.09.008

Mazumdar, A., Peketi, A., Dewangan, P., Badesab, F., Ramprasad, T., Ramana, M. V., Patil, D.J., Dayal, A., 2009. Shallow gas charged sediments off the Indian west coast: Genesis and distribution. Mar. Geol. 267, 71-85. https://doi.org/10.1016/j.margeo.2009.09.005

Mellet, C., Long, D., Carter, G., Chiverell, R., Van Landeghem, K., 2015. Geology of the seabed and shallow subsurface: The Irish Sea. British Geological Survey Commissioned Report, CR/15/057. $52 \mathrm{pp}$.

National Parks and Wildlife, 2015. Codling Fault Zone SAC Site Synopsis. Republic of Ireland.

Newman, P.J., 1999. The geology and hydrocarbon potential of the Peel and Solway Basins, East Irish Sea. J. Pet. Geol. 22, 305-324. https://doi.org/10.1111/j.1747-5457.1999.tb00989.x

Noble-James, T., Judd, A., Diesing, M., Clare, D., Eggett, A., Silburn, B., Duncan, G., 2020. Monitoring shallow methane-derived authigenic carbonate: Insights from a UK Marine Protected Area. Aquat. Conserv. Mar. Freshw. Ecosyst. 1-18. https://doi.org/10.1002/aqc.3296

O’Reilly, S.S., Hryniewicz, K., Little, C.T.S., Monteys, X., Szpak, M.T., Murphy, B.T., Jordan, S.F., Allen, C.C.R., Kelleher, B.P., 2014. Shallow water methane-derived authigenic carbonate mounds at the Codling Fault Zone, western Irish Sea. Mar. Geol. 357, 139-150. https://doi.org/10.1016/j.margeo.2014.08.007

O'Reilly, S.S., 2018, personal communications via email with Mark Coughlan, 04/12/2028.

Pharaoh, T.C., Smith, N.J.P., Kirk, K., Kimbell, G.S., Gent, C., Quinn, M., Monaghan, A.A., 2016. Palaeozoic Petroleum Systems of the Irish Sea Energy and Marine Geoscience Programme, British Geological Survey Commissioned Report. 
Portnov, A., Vadakkepuliyambatta, S., Mienert, J., Hubbard, A., 2016. Ice-sheet-driven methane storage and release in the Arctic. Nat. Commun. 7, 10314. https://doi.org/10.1038/ncomms10314

Ramprasad, T., Dewangan, P., Ramana, M. V, Mazumdar, A., Karisiddaiah, S.M., Ramya, E.R., Sriram, G., 2011. Evidence of slumping/sliding in Krishna-Godavari offshore basin due to gas/fluid movements. Mar. Pet. Geol. 28, 1806-1816. https://doi.org/https://doi.org/10.1016/j.marpetgeo.2011.02.007

Rathburn, A.E., Levin, L.A., Held, Z., Lohmann, K.C., 2000. Benthic foraminifera associated with cold methane seeps on the northern California margin: Ecology and stable isotopic composition. Mar. Micropaleontol. 38, 247-266. https://doi.org/https://doi.org/10.1016/S0377-8398(00)00005-0

Roelofse, C., Alves, T.M., Gafeira, J., 2020. Structural controls on shallow fluid flow and associated pockmark fields in the East Breaks area, northern Gulf of Mexico. Mar. Pet. Geol. 112, 104074. https://doi.org/10.1016/j.marpetgeo.2019.104074

Roy, S., Hovland, M., Noormets, R., Olaussen, S., 2015. Seepage in Isfjorden and its tributary fjords, West Spitsbergen. Mar. Geol. 363, 146-159. https://doi.org/https://doi.org/10.1016/j.margeo.2015.02.003

Roy, S., Senger, K., Braathen, A., Noormets, R., Hovland, M., Olaussen, S., 2014. Fluid migration pathways to seafloor seepage in inner isfjorden and Adventfjorden, Svalbard. Nor. Geol. Tidsskr. 94, 99-199.

Roy, S., Senger, K., Hovland, M., Römer, M., Braathen, A., 2019. Geological controls on shallow gas distribution and seafloor seepage in an Arctic fjord of Spitsbergen, Norway. Mar. Pet. Geol. 107, 237-254. https://doi.org/https://doi.org/10.1016/j.marpetgeo.2019.05.021

Sills, G.C., Wheeler, S.J., 1992. The significance of gas for offshore operations. Cont. Shelf Res. 12, 12391250.

Society for Underwater Technology, 2005. Guidance Notes on Site Investigations for Offshore Renewable, Guidance notes on site investigations for offshore renewable energy projects.

Sultan, N., de Gennaro, V., Puech, A., 2012. Mechanical behaviour of gas-charged marine plastic sediments. Geotechnique 62, 751-766. https://doi.org/10.1680/geot.12.0G.002

Sun, Q., Alves, T., Xie, X., He, J., Li, W., Ni, X., 2017. Free gas accumulations in basal shear zones of masstransport deposits (Pearl River Mouth Basin, South China Sea): An important geohazard on continental slope basins. Mar. Pet. Geol. 81, 17-32. https://doi.org/https://doi.org/10.1016/j.marpetgeo.2016.12.029

Sun, Q., Wu, S., Hovland, M., Luo, P., Lu, Y., Qu, T., 2011. The morphologies and genesis of megapockmarks near the Xisha Uplift, South China Sea. Mar. Pet. Geol. 28, 1146-1156. https://doi.org/https://doi.org/10.1016/j.marpetgeo.2011.03.003

Szpak, M.T., Monteys, X., O’Reilly, S., Simpson, A.J., Garcia, X., Evans, R.L., Allen, C.C.R., McNally, D.J., Courtier-Murias, D., Kelleher, B.P., 2012. Geophysical and geochemical survey of a large marine pockmark on the Malin Shelf, Ireland. Geochemistry, Geophys. Geosystems 13, 1-18. https://doi.org/10.1029/2011GC003787

Szpak, M.T., Monteys, X., O’Reilly, S.S., Lilley, M.K.S., Scott, G.A., Hart, K.M., McCarron, S.G., Kelleher, B.P., 2015. Occurrence, characteristics and formation mechanisms of methane generated micropockmarks in Dunmanus Bay, Ireland. Cont. Shelf Res. 103, 45-59. https://doi.org/10.1016/j.csr.2015.04.023

Thomas, I.W., 1978. Well 33/22-1 Completion Report.

Tóth, Z., Spieß, V., Jensen, J., 2014. Seismo-acoustic signatures of shallow free gas in the Bornholm Basin, Baltic Sea. Cont. Shelf Res. 88, 228-239. https://doi.org/https://doi.org/10.1016/j.csr.2014.08.007

Van Landeghem, K.J.J., Niemann, H., Steinle, L.I., O’Reilly, S.S., Huws, D.G., Croker, P.F., 2015. Geological settings and seafloor morphodynamic evolution linked to methane seepage. Geo-Marine Lett. 35, 
289-304. https://doi.org/10.1007/s00367-015-0407-5

Vanneste, M., Sultan, N., Garziglia, S., Forsberg, C.F., L'Heureux, J.S., 2014. Seafloor instabilities and sediment deformation processes: The need for integrated, multi-disciplinary investigations. Mar. Geol. 352, 183-214. https://doi.org/10.1016/j.margeo.2014.01.005

Ward, S.L., Neill, S.P., Landeghem, K.J.J. Van, Scourse, J.D., 2015. Classifying seabed sediment type using simulated tidal-induced bed shear stress. Mar. Geol. 367, 94-104. https://doi.org/10.1016/j.margeo.2015.05.010

Webb, K.E., Barnes, D.K.A., Plankea, S., 2009. Pockmarks: Refuges for marine benthic biodiversity. Limnol. Oceanogr. 54, 1776-1788. https://doi.org/10.4319/lo.2009.54.5.1776

Woods, M.A., Wilkinson, I.P., Leng, M.J., Riding, J.B., Vane, C.H., Lopes dos Santos, R.A., Kender, S., De Schepper, S., Hennissen, J.A.I., Ward, S.L., Gowing, C.J.B., Wilby, P.R., Nichols, M.D., Rochelle, C.A., 2019. Tracking Holocene palaeostratification and productivity changes in the Western Irish Sea: $A$ multi-proxy record. Palaeogeogr. Palaeoclimatol. Palaeoecol. 532, 109231. https://doi.org/https://doi.org/10.1016/j.palaeo.2019.06.004

Xing, J., Jiang, X., Li, D., 2016. Seismic study of the mud diapir structures in the Okinawa Trough. Geol. J. 51, 203-208. https://doi.org/10.1002/gj.2824

Yilmaz, Ö., 2001. Seismic Data Analysis: Processing, Inversion, and Interpretation of Seismic Data. Society of Exploration Geophysicists, Tulsa.

Yuan, F., Bennell, J.D., Davis, A.M., 1992. Acoustic and physical characteristics of gassy sediments in the western Irish Sea. Cont. Shelf Res. 12, 1121-1134.

\section{Figure Captions}

Figure 1 Overview of the location of study areas (A-D) within the Irish Sea along with 2D reflection seismic lines and borehole locations referred to in the text superimposed on previously mapped areas of sub-cropping Carboniferous rocks, Mesozoic sedimentary basins (both accessed from EMODNet) and structural lineaments (Anderson, 2013; Anderson et al., 2016). Also included are Special Areas of Conservation (SAC) and Marine Conservation Zones (MCZ) related to gas features and the extent of the Western Irish Sea Mud Belt. Please note that the Carboniferous potential source rock is present in the Permian-Triassic basins.

Figure 2 (A) Simplified lithostratigraphic column of the bedrock geology of the Western Irish Sea. (B) Simplified lithostratigraphic column of the Quaternary section discussed in this study.

Figure 3 2D multichannel seismic line E95IE18-03 and accompanying geoseismic interpretation. Image quality degrades significantly within the Codling Fault Zone due to a combination of structural 913 complexity and shallow gas-related features. Inset: Several shallow gas related features are identified 914 within the Codling Fault Zone, including seabed brightening with a sharp boundary above a major, near- 
seabed splay of the Codling Fault Zone, and reverse polarity anomalies with associated seismic blanking and signal dispersion.

Figure 4 2D multichannel seismic line IS-12 and accompanying geoseismic interpretation. The graben fill is predicted to be of Permian-Triassic sediment, similar to the stratigraphy of the along-strike Peel Basin. The faults bounding the graben are observed to offset the Base-Cenozoic Unconformity, indicating recent tectonic activity and representing possible fluid-migration pathways.

Figure 5 2D multichannel seismic line JSM92-30 and accompany geoseismic interpretation. Several 924 minor faults are observed offsetting the Base-Cenozoic Unconformity in the Queenie Corner area.

Figure 6 Seabed mounds observed at the southern part of the study area (within the Codling Fault Zone) are interpreted as carbonate mounds which form as a result of prolonged seepage at the seafloor. Sediment waves are predominant in this region of the study area. A and B highlight the mound 929 structures in close up (note different water depth scales for better visualization of the mounds). High 930 backscatter is evident at these two locations. Refer to Fig. 1 for location.

Figure 7 (A) High-resolution bathymetric data illustrating seafloor morphology at Lambay Deep, along 933 with (B) vertical profile across the $1 \mathrm{~km}$ wide depression. (C) Zoom-in of the bathymetric high which is 934 characterized by high-backscatter (D). Refer to Fig. 1 for location.

Figure 8 Lambay Deep as imaged by sparker seismic data with interpreted units. Highlighted is the mound referred to as the Lambay Deep Mud Diapir (LDMD) and acoustic evidence for shallow gas 938 (acoustic turbidity and enhanced reflections). ' $M$ ' denotes seabed multiple. Unit names are referenced 939 from Figure 2. Yellow line is the top of UT (Upper Till member), blue line is top of PF (Prograded Facies), SSF is Surface Sands Formation. Red line denotes the edge of the LDMD. Dashed black line is the top of 941 the shallow gas.

Figure 9 Depth to the top of the gas accumulation (interpreted on a grid of 2D sparker seismic lines shown in Fig. 1 of Coughlan et al., (2019), identified in the Western Irish Sea Mud Belt superimposed on water depth from MBES data. Highlighted are the pockmarks described in Supplementary Material, the 946 location of seismic lines presented in Fig. 10 and the pockmarks presented in detail in Fig. 11. 
Figure 10 Sparker seismic lines highlighted in Fig. 9 from the WISMB with interpreted units. Also presented is evidence for shallow gas accumulation (enhanced reflection, acoustic turbidity, acoustic blanking). ' $M$ ' denotes seabed multiple. Unit names are referenced from Figure 2. Full black line indicates the top of bedrock. Yellow line is the top of UT (Upper Till member), green line is the top of CF (Chaotic Facies), blue line is top of PF (Prograded Facies). Dashed black line denotes the gas front.

Figure 11 High-resolution bathymetric data illustrating $(A)$ a central mound within pockmark P15, and (B) morphology of a circular pockmark P13 without a central mound along with their vertical profiles. (C) Central mounds within pockmarks P10 and P11, which are separated by approximately $1 \mathrm{~km}$. Refer to Fig. 9 for locations.

Figure 12 High-resolution multibeam bathymetric data (top) and backscatter data (bottom) of the Queenie Corner area seafloor. Refer to Fig. 1 for location. A closer illustration of the seabed mound structures of various sizes and shapes (sub-circular to elongated) have been shown along with their vertical profiles.

Figure 13 Pinger profile highlighted in Fig. 12 from Queenie Corner illustrates acoustic evidence for shallow gas in the form of gas chimneys (a) and acoustic blanking (b). Seabed mounds are observed at the top of gas chimneys (a).

Figure 14 Conceptual model proposed for fluid migration from deeper thermogenic source rocks via recently reactivated fault conduits to shallow gas-charged Quaternary sediments in the Western Irish Sea Mud Belt. Subsequently, some of the gas migrates upwards to the seafloor, leading to the formation of pockmarks (due to fluid seepage) and seabed mounds (due to increase of pressure and volume within sediment pores).

Figure 15 Overview map of shallow gas accumulations and fluid seepage features identified in this study along with similar features identified from other referenced studies. This information is superimposed on the British Geological Survey DigSBS250 database, which maps seabed sediment distribution. according to the Folk Classification, in the Irish Sea at a scale of 1:250,000. Some pockmarks from this study are seen to form above a mapped shallow gas accumulation with mud-dominated sediments, 

985

generally pockmarks (this study) are concentrated in areas with a sandier component. Seabed mound features in this study were found in areas where the seabed sediment is mud-dominated.

982 Figure 16 Conceptual models proposed for $(A)$ the formation of mounds at the centre of pockmarks in 983 sand-rich sediments and (B) seabed mounds in mud-rich sediments as a precursors to collapsed 984 pockmarks, , adapted from previous studies (Hovland, 2002; Crémière et al. 2018; Loher et al. 2018).

\section{Table Captions}

987 Table 1 List of surveys from which data were used in this study. 
1 Geological settings and controls of fluid migration and associated seafloor

2 seepage features in the north Irish Sea

3

4 Mark Coughlan ${ }^{1,3 *}$, Srikumar Roy ${ }^{2,3}$, Conor O'Sullivan ${ }^{2,3}$, Annika Clements $^{4}$, Ronan O'Toole ${ }^{5}$, Ruth Plets ${ }^{6,7}$

$6 \quad{ }^{1}$ School of Civil Engineering, University College Dublin, Newstead, Belfield, Dublin 4, Ireland.

$7 \quad{ }^{2}$ School of Earth Sciences, Science Centre West, University College Dublin, Belfield, Dublin 4, Ireland.

$8{ }^{3}$ Irish Centre for Research in Applied Geosciences, O'Brien Centre for Science East, University College

9 Dublin, Belfield, Dublin 4, Ireland

${ }^{4}$ Seafish, 18 Logie Mill, Logie Green Road, Edinburgh.

${ }^{5}$ Geological Survey of Ireland, Beggars Bush, Dublin, Ireland

${ }^{6}$ School of Geography and Environmental Sciences, Ulster University, Coleraine, Northern Ireland.

${ }^{7}$ Flanders Marine Institute, Wandelaarkaai 7, 8400 Ostend, Belgium

\section{ABSTRACT}

Shallow gas accumulation in unconsolidated Quaternary sediments, and associated seepage at the seafloor, is widespread in the north Irish Sea. This study integrates high-resolution seafloor bathymetry and sub-surface geophysical data to investigate shallow gas accumulations and possible fluid (gas and/or liquids) migration pathways to the seafloor in the northern part of the Irish Sea. Shallow gas occurs broadly in two geological settings: the Codling Fault Zone and the Western Irish Sea Mud Belt. The gas has been recognised to accumulate in both sandy and muddy Quaternary marine near-surface sediments and is characterised by three characteristic sub-bottom acoustic features: i) enhanced reflections, ii) acoustic turbid zones, and iii) acoustic blanking. The seepage of shallow gas at the seafloor has resulted in the formation of morphological features including methane-derived authigenic carbonates, seabed mounds and pockmarks. In many instances, the evidence for this gas as biogenic or thermogenic in origin is inconclusive. Two distinct types of pockmarks are recorded in the Western Irish Mud Belt: pockmarks with a relatively flat centre, and pockmarks with a central mound. Based on our observation and existing models, we infer that the formation of athin carbonate crust at the seabed surface, is needed as a precursor for the creation of such mounds within 
pockmarks.- The formation processes are interpreted to be different for sandy versus muddy sediments, due to variability in erodibility and sealing capacities of the substrate. We suggest that the origin of

33 these features is linked to the presence of adeeperpotential hydrocarbon source rocks with existing

34 and reactivated faults forming fluid migration pathways to the surface. This in turn could indicate a

35 mixed thermogenic-biogenic origin for seep-related-tocations associated structures in the study area.

36 These features have significant implications for the future development of offshore infrastructure including marine renewable energy as well as for seabed ecology and conservation efforts in the Irish Sea.

Keywords: pockmark, seabed mounds, fluid seepage, MDAC, mud diapir, geohazards, ecological conservation, offshore infrastructure

\section{INTRODUCTION}

\section{The accumulation ofShallow gas in shallow, unconsolidated marine sediments is aa global} phenomenonglobally widespread (Andreassen et al., 2007; Dondurur et al., 2011; Ergün et al., 2002; 45 Hovland and Judd, 1992; Karisiddaiah and Veerayya, 1994; Mazumdar et al., 2009). It represents an 46 important tool for frontier-exploration of hydrocarbon exploration, while also posingreservoirs, as well as being a significant geohazard, affecting sediment engineering properties (Andreassen et al., 2007; Hovland et al., 2002; Sills and Wheeler, 1992). The impacts of shallow gas and seepage on seabed 49

50 al., 2000). To date in the Irish Sea (Fig. 1), a number of areas associated with shallow gas and fluid 51 seepage have been designated as Special Areas of Conservation (SAC) due to the unique habitats they 52 form as "Submarine structures made by leaking gases", according to the Annex I / II of the E.U. Habitats 53 Directive (National Parks and Wildlife, 2015). These can form two described habitat types: Bubbling 54 Reefs and Structures within Pockmarks. In the Irish Sea, the SAC areas are predominantly related to 55 Methane-Derived Authigenic Carbonates (MDAC) and are known locally as the Codling Fault Zone (CFZ) SAC and Croker Carbonate Slabs (CCS) SAC (Fig. 1). Further north, Queenie Corner is an offshore site within the Western Irish Sea Mud Belt (WISMB) that was designated as a UK Marine Conservation Zone (MCZ) in 2019 for its subtidal mud habitat and sea-pen and burrowing megafauna communities (Clements and Service, 2016). 
61 Shallow gas in unconsolidated marine sediments can have a biogenic or thermogenic origin. Bulk isotopic analysis on samples from the CFZ by O'Reilly et al. (2014) indicate a biogenic origin of the seeping gas, with some possible thermogenic contribution from underlying Carboniferous coal deposits. Methanogenesis of organic-rich Quaternary sediments has been proposed as a source for shallow gas in Bantry Bay (Jordan et al., 2019) and Dunmanus Bay (Szpak et al., 2015) elsewhere in Irish waters.

Evidence for shallow gas accumulations and seepage in the Irish Sea has been detected from geophysical observations on seismic lines as gas chimneys, enhanced reflectors and acoustic turbidity (e.g. Judd and Hovland (1992)). Where fluids (e.g. methane gas) emanate from the seabed, morphological features such as mounds and pockmarks have formed in the Western Irish Sea (Croker et al., 2005).

Mounds are elevated bathymetrictopegraphic seafloor features which can-either form due to upward migrating fluids exerting pressure on overlying relatively impermeable layers or precipitation of carbonates due to prolonged methane gas seepage. Owing to their different formation mechanism, they are known as seabed domes, mud diapirs, and carbonate mounds, all of which have been found in the Irish Sea (Croker et al., 2005). Hovland and Curzi (1989) documented seabed domes and mud diapirs in the Adriatic Sea offshore Italy, where gas bubbles concentrating in plastic clay caused local density reversals, resulting in the upward buoyant flow of the clay and deformation of overlying unlithified

78 layers, thus forming elevated bathymetrictopographical features at the seafloor and associated gas seepages. Such seabed domes and mud diapirs have also been found offshore India (Ramprasad et al., 80 2011), in Norwegian Arctic fjords (Roy et al., 2014), and offshore New Zealand (Koch et al., 2015). Croker et al. (2005) previously mapped mounds (referred to as "seabed doming") in the WISMB, and suggested that they may have formed due to the replacement of water in the pore space with gas causing an increase in sediment volume in the upper sediment layers. For this to occur, fine-grained, relatively impermeable sediments are required. Croker et al. (2005) also suggested that seabed doming might be an initial stage of pockmark formation. Mounds can also form when prolonged methane gas seepage at the seabed chemically interacts with surrounding minerals to form a carbonate precipitate cement (MDAC), binding the sediment matrix and forming hard, resistive rocksfock-like substances (Judd et al., 2019). With continued seepage over time, MDACs can continue to precipitate and grow into sizeable 2014). 
Pockmarks are the most common manifestations of fluid seepage on the seafloor and are formed by specifically the CFZ and WISMB, has been previously documented (e.g. Croker et al. (2005)). Geochemical analysis of the seep and mound locations suggest mixed biogenic and thermogenic signatures (Judd et al., 2019; O’Reilly et al., 2014). However, factors such as structural and stratigraphic features responsible for the migration of fluids responsible for a thermogenic signature are still poorly understood. Furthermore, models applicable to the formation mechanisms of the seep-related seafloor features in the Irish Sea are lacking. With this in mind, the aims The aim of this study areis therefore twofold:

(i) To spatially map and characterise geophysical evidence for shallow gas, fluid migration and seafloor seepage in the north Irish Sea;

(ii) To establish a geological framework incorporating bedrock geology, hydrocarbon source rocks, structural geology (faults), Quaternary geology and seafloor morphology in the Irish Sea which will facilitate further studies into subsurface fluid flow mechanisms;

To(i) to provide a revised geological model to investigate the potentialsources of thermogenic gas in

the north Irish Sea (namely the CFZ and WISMB), as well as the direct fluid pathways and stratigraphic controls that allow it to migrate to shallow sub-seabed accumulations and form seep-related seafloor features, and; (ii) to suggest theories of seabed mound and pockmark formation in the WISMB.

Formatted: List Paragraph, Numbered + Level: 1 + Numbering Style: i, ii, iii, ... + Start at: $1+$ Alignment: Right + Aligned at: $0.63 \mathrm{~cm}+$ Indent at: $1.9 \mathrm{~cm}$ 
To achieve this, we provide an integrated analysis of shallow high-resolution datasets (sub-bottom acoustic, multibeam echosounder bathymetry and backscatter data) and deep 2D multichannel seismic datasets from the north Irish Sea. Inferences are made on the formation mechanisms of seep-related seabed features which can be used to better predict their likely-distribution elsewhere in the region. Finally, the implications of shallow gas and fluid-seepage at the seafloor are considered in the context of marine infrastructure siting and ecological conservation.

\section{BACKGROUND GEOLOGY}

The bedrock geology of the Irish Sea is characterised by a series of rift basins with several kilometres of Carboniferous, Permian and Triassic sedimentary fill. These basins formed through a series of extensional events in the Carboniferous, Permian and Jurassic, punctuated by episodes of uplift during the Late Carboniferous Variscan Orogeny and more recently the Alpine Orogeny during the Cenozoic. During the Cenozoic event, the Irish Sea experienced kilometre-scale uplift resulting in the present-day configuration of erosional outliers, which are remnants of a much larger rift system (Jackson and Mullholland, 1993). These rift basins include the Kish Bank Basin and Peel Basin, both of which have been the focus of hydrocarbon exploration during the last fifty years (Fig. 1) (Dunford et al., 2001; Newman, 1999). Lithologies capable of generating hydrocarbons have been encountered in the Carboniferous, including the gas-prone Pennine Coal Measures Group and the oil-prone Bowland Shale Formation (Fig. 2). These source rocks have generated significant quantities of hydrocarbons, with an estimated 1.8 BBOE (Billion Barrels of Oil Equivalent) discovered in the East Irish Sea Basin (Bunce, 2018). Similar exploration activities took place in the western Irish Sea, primarily in the Kish Bank Basin, with four wells drilled between 1977 and 1997. While no commercial discoveries were made, the presence of the Pennine Coal Measures Group was proven in the 33/22-1 well on the southern margin of the Kish Bank Basin (Thomas, 1978).

The bedrock in the Irish Sea has largely been blanketed with Quaternary sediments, collectively referred to as the Brython Glacigenic Group (Fig. 2). Subglacial sediments were deposited by the Irish Sea Ice Stream (ISIS) during the Last Glacial Maximum are referred to as the Upper Till (UT) member (Fig. 2), and comprise a till containing stiff or hard clay with clasts ranging in size from sand-grade to boulders up to 1 m (Jackson et al., 1995). Overlying the UT are a series of units deposited in a glaciomarine to marine environment as the ISIS retreated, referred to as the Western Irish Sea Formation (WISMF) (Fig. 2) 
(Jackson et al., 1995). Included in this formation, at the base, is the Chaotic Facies (CF). This unit consists of ice-proximal sediments, dominated by gravels with silts, sands and cobble-grade components (Coughlan et al., 2019; Jackson et al., 1995). The overlying Prograding Facies (PF) is-described as being composed of fine- to medium-grained sands that are tabular stratified, having been deposited in a marine environment in front of the retreating Irish Sea Ice Stream (ISIS) (Coughlan et al., 2019; Jackson et al., 1995). The Mud Facies (MF) is characterised by stratified grey-brown muddy sands with silts and clays and is interpreted as being deposited in a fully marine environment (Coughlan et al., 2019; Woods et al., 2019). The organic-rich sediments of the MF have been identifiedsuggested as a potentialthe source of shallow gas (biogenic-origin) in the north Irish Sea in the Western Irish Sea Mud Belt. The anaerobic decomposition of the organic-rich sediments followed by rapid burial under high sedimentation rates during marine transgression in the Early Holocene produced biogenic gas in the shallow sediments (Yuan et al., 1992). The UT and WISF deposits have been reworked during marine transgression and sea-level rise in the Holocene forming a complex distribution of sediments and bedforms, collectively referred to as the Surface Sands Formation (SSF) (Fig. 2) (Jackson et al., 1995; Ward et al., 2015)(Jackson et al., 1995; Ward et al., 2015).

\section{DATA AND METHODS}

This study uses a variety of shallow and deep geophysical datasets. The shallow datasets used in this study include multibeam echosounder (MBES) bathymetry and backscatter data as well as shallow sparker and pinger seismic data from a variety of surveys (Table 1). They were acquired primarily as part of the Integrated Mapping for the Sustainable Development of Ireland's Marine Resource (INFOMAR) programme, delivered by the Geological Survey of Ireland (GSI) and Marine Institute of Ireland. Data collected by the Agri-Food and Biosciences Institute (AFBI) in collaboration with GSI and by a Natural Environment Research Council (NERC) sponsored survey (NE/H02431/1) is accessed for Queenie Corner.

\section{Multibeam echosounder data}

The high-resolution multibeam datasets were collected with the EM3002D multibeam echosounder (MBES) onboard the RV Celtic Voyager (dual head) and RV Corystes (single head) acquiring bathymetry data in the $300 \mathrm{kHz}$ range using dynamically focused beams. The horizontal accuracy ( $x, y)$ was usually 
less than $50 \mathrm{~cm}$ with a vertical accuracy $(\mathrm{z})$ of $<15 \mathrm{~cm}$ obtained for the processed bathymetry data. Data processing was performed on board with the CARIS HIPS and SIPS software package to remove HIPS and SIPS software consisted of un-gridded, tidally corrected XYZ data that was subsequently gridded using QPS Fledermaus v.7 to a $2 \mathrm{~m}$ cell resolution. Gridded raster data was then exported to ArcGIS v10 and Fledermaus v.7.7.6 for 3D visualization and morphological analysis of seafloor features. Relative backscatter values were obtained from the strength of the return signal during MBES acquisition. Data were processed using Geocoder in CARIS HIPS and SIPS and exported into ESRI ArcGIS in gridded formats.

\section{Sub-bottom acoustic data}

Seismic sparker data were gathered using a Geo-Source 400 sparker system. The system consisted of a 6 $\mathrm{kJ}$ pulsed power supply operating predominantly at a frequency of $0.5-2 \mathrm{kHz}$.predominantly. The unfiltered return signal was picked up usingin a Geo-Sense single channel hydrophone array. A maximum penetration of $50 \mathrm{~m}$ below the seabed was achieved with a vertical resolution of up to $30 \mathrm{~cm}$. Seismic sparker data were incorporated into IHS Kingdom software in SEG-Y format and merged with ASCII navigation data before being processed and interpreted. A trapezoid bandpass filter was applied (low pass value $0.9-1.2 \mathrm{kHz}$, high pass value $5-6 \mathrm{kHz}$ ) and an automatic gain control of 50 and $100 \mathrm{~ms}$. Horizons were picked manually, and seismic depths were converted from two-way travel time to metres using an acoustic internal velocity of $1600 \mathrm{~m} \mathrm{~s}^{-1}$ through shallow marine sediments. Seismic pinger data were collected from Queenie Corner using a hull-mounted SES 5000 3.5kHz pinger system with a $200 \mathrm{~ms}$ duration. Data were acquired using the CODA system and processed using IHS Kingdom.

\section{D multichannel seismic data}

The 2D multichannel reflection seismic data used in this study consisted of a multi-vintage database of six surveys acquired as part of the hydrocarbon exploration activities in the Irish sea. These seismic surveys were acquired between 1983 and 1995, comprising over 2,800 kilometres of data, and processed as per industry standards (Yilmaz, 2001).- The majority of the seismic data are centred on the Kish Bank Basin, with five 2D seismic surveys not extending significantly beyond the bounds of the basin. Coverage of the remainder of the study area is provided by a single reconnaissance survey acquired by 
WesternGeco in 1983, which covers the entirety of the Irish sector of the Irish Sea. Stratigraphic control associated with these boreholes consists of wireline logs (gamma ray, caliper, neutron-density, sonic, and resistivity logs), well completion reports, formation tops, and time-depth relationship data in the form of checkshots. Seismic interpretation of key stratigraphic horizons and seismic to well tie was carried out in Petrel software.

\section{RESULTS AND INTERPRETATION}

\section{D multichannel seismic data}

A 2D multichannel reflection seismic dataset, consisting of several discrete surveys, was used to investigate the bedrock geology of the region, structural lineaments and gas related features. Six key horizons were mapped in the vicinity of the Lambay Deep and Kish Bank Basin where formation tops from four hydrocarbon exploration boreholes provided stratigraphic control: (i) Seabed; (ii) BaseQuaternary; (iii) Base-Cenozoic; (iv) Top Lower Triassic; (v) Top Permian; (vi) Top Basement (Carboniferous \& older) (Fig. 1 and Fig. 3).

Where the Codling Fault Zone transects the Kish Bank Basin, a number of seismic amplitude anomalies are observed in the upper Cenozoic section. These seismic amplitudes are locally distributed, includingThese include distinct seabed brightening, and widespread reverse-polarity anomalies (Fig. 3). These features are confined to the Codling Fault Zone and are not observed in other areas of the Kish Bank Basin. TheyThese shallow features cause acoustic blanking of the deeper section, either due to absorption or reflection of acoustic energy, significantly reducing seismic image quality at depth.

Absorption of acoustic energy can be caused due to presence of gas in the upper stratigraphic sediments, whereas reflection could be attributed to the presence of high-density rocks such as igneous bodies. The latter is unlikely, as igneous bodies have not been documented in the upper Cenozoic sediments in this part of the Irish Sea. These features are confined to the Codling Fault Zone and are not observed in other areas of the Kish Bank Basin.

There is limited stratigraphic control beyond the Kish Bank Basin, towards the Peel Basin (Fig. 1). Data quality is pooralso poorer here, owing to the limited reflectivity within the Palaeozoic section. 
Therefore, only the Base-Cenozoic unconformity could be reliably interpreted. A small half-graben was identified in the north of the study area (i.e. the WISMB; Fig. 1 and Fig. 4) which at present remains undrilled. Owing to its location along strike from the Peel Basin in the UK sector of the Irish Sea, this minor graben is interpreted as an erosional outlier, and the stratigraphy is inferred to be Permian and Triassic, similar to that of the Peel Basin (Floodpage et al., 2001). The bounding faults of this small graben are observed to offset the Base-Cenozoic surface, indicating relatively recent tectonic activity, and the areal extent of this graben correlates with the extent of the acoustic turbidity mapped on subbottom profiler sections (Fig. 4).

Further east within the WISMB, underlying the Queenie Corner area, a 2D reflection seismic line images folded Carboniferous rocks at depth, overlain by Cenozoic sediments (Fig. 5). Similar to structures observed in Fig. 3, several minor faults are observed offsetting the Base-Cenozoic Unconformity and represent relatively recent tectonic activity (Fig. 5).

\section{Multibeam and Sub-bottom acoustic data}

\section{Codling Fault Zone}

The seabed in the Codling Fault Zone is dynamic with extensive sediment waves (Croker et al., 2005) (Fig. 6). Also prominent are mounds, which form distinctive bathymetric highs relative to the surrounding seafloor. Approximately 23 mounds have been described previously by O'Reilly et al. (2014) and Van Landeghem et al. (2015) and been interpreted as carbonate mounds. This study identified a further two mounds which exhibit a roughly circular morphology and have an approximatea diameter of $60 \mathrm{~m}$ approximately(Fig. 6). They protrude 8 and $16 \mathrm{~m}$ respectively from the seabed and have a higher backscatter than the surrounding seafloor. Based on their morphological similarity and proximity with the carbonate mounds identified Van Landeghem et al. (2015), we infer that these two mounds are probably also carbonate mounds (MDAC) formed due to prolonged seepage of methane gas from the seafloor. However, geochemical sampling and ROV image grabs would be required to ground-truth their association with gas seepage. 
The Lambay Deep itself is a pronounced bathymetric low on the seabed, forming a linear trough-like feature broadly oriented NW-SE that is approximately $11 \mathrm{~km}$ long, Deep is $135 \mathrm{mbsl}$ at its deepest point and is generally $50 \mathrm{~m}$ deepertower than the surrounding seabed (Fig. 7). The northern extent of the Lambay Deep is bound by an area of exposed bedrock, identified by its rugged seafloor morphology and high backscatter. At its southern extent, the Deep is bound by a sediment wave field. Located near the centre of the Deep is a prominent mound forming a bathymetric high with a clear backscatter contrast to the surrounding seabed (Fig. 7).

The sparker data acquired over the Lambay Deep cover the area above the mound, where we observe an acoustically transparent unit with a thickness of about $24 \mathrm{~m}$ thick unit, above an enhanced reflection (LD-1, Fig. 8). The western flank exhibits acoustic turbidity. These acoustic anomalies are possibly attributed to the accumulation of shallow gas beneath the mound, which was earlier described by Croker et al. (2005) as the Lambay Deep Mud Diapir (LDMD). To the east of the LDMD, low-amplitude parallel to sub-parallel reflections characterise the sedimentary sequence. The acoustic turbidity zone is

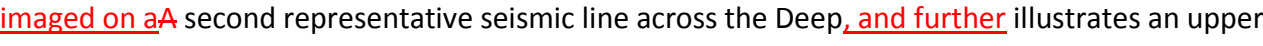
acoustic unit displaying an almost transparent seismic signature with faint, horizontal, parallel laminations overlying an enhanced reflection in the centre of the deep (LD-2, Fig. 8). The enhanced reflections imaged in both these sparker linesfeflection could be possibly attributed to the sharp acoustic impedance contrast between the underlying gas charged sediments and the overlying lithology. Hence, the enhanced reflections are interpreted as top of shallow gas accumulation. The flanks exhibit a more complex stratigraphy with chaotic acoustic units bounded by moderate to strong internal reflectors. The acoustic turbid zones are possibly caused due to scattering of acoustic energy by gas which is finely disseminated within impervious clay-rich sediments. The sedimentary strata on either side of the LDMD exhibit onlapping structures, which is typical at mud diapir locations (Fig. 8). Onlapping stratigraphy on either side of the LDMD suggest uplifting due to the structure (Fig. 8).

\section{Western Irish Sea Mud Belt}

\section{As described earlier, the enhanced reflection is interpreted as the The-top of the shallow gas} accumulation zone in the WISMB, which lies between 8 and 18 mbsf and extends across an area of approximately $90 \mathrm{~km}^{2}$ (Fig. 9). The accumulation has an inverted bowl topography with the rims climbing down towards its edges, and an enhanced reflection marks the top (Fig. 10). The upper layers in the gas- 
charged zone are lenticular, and characterized by an acoustically turbid zone, while exhibiting a sharp contrast to the surrounding sediments (Fig. 10). Sub-bottom acoustic anomalies related to shallow gas accumulation in this area of the WISMB and details on the shallow seismic stratigraphy have previously been documented by Coughlan et al. (2019).

Circular to sub-circular crater like features were identified on bathymetry data, which were interpreted as pockmarks which are direct indicators of fluid seepage at the seafloor. A total of seventeen pockmarks (P1-17) were identified using the slope tool in ArcGIS to highlight slope changes along pockmark walls. All pockmarks in this study (with the exception of P12) were found in water depths greater than $40 \mathrm{~m}$ (Fig. 9). Information on calculated dimensions and morphology for each pockmark is presented in the supplementary material (S1). Two separate morphologies were identified: pockmarks with central mounds within them and pockmarks without any central mounds.

P1, P2 and P3 are clustered with a distance of $355 \mathrm{~m}$ between P1 and P2 and a further $420 \mathrm{~m}$ between P2 and P3 in a northerly direction. Other pockmarks along this trend are more widely spaced. Pockmarks P1 to P12 are sub-circular in shape, although P5-P8 are more elongateelongated. The alignments of the long-axis of the elongate pockmarks are in different orientations suggesting no influence of bottom currents on the morphological evolution of the pockmarks. Relief relative to the seabed varies between $0.6 \mathrm{~m}$ (P3) and 1.6m (P10) with pockmarks becoming generally larger and deeper to the northwest. P12 is a typical giant irregular pockmark, as documented in the UK North Sea (Cole et al., 2000). It is elliptical in plan-view, and at least 5 times larger than any of the other pockmarks in this group, the short and long axis being c. $500 \mathrm{~m}$ and $1000 \mathrm{~m}$ (Fig. 11A). Backscatter data for P12 display higher reflectance values than the surrounding sediments (Fig. 11B). Higher reflectance could either be due to coarser sediments or due to carbonate precipitates near the seabed owing to prolonged seepage. We infer the tater to be a more likely explanation to the high backscatter values from the centre of this giant irregular pockmark P12.

Most pockmarks in this study are between 74 and $153 \mathrm{~m}$ wide with P7, P10 and P11 being 171 to $268 \mathrm{~m}$ wide. P4 and the larger P10 and P11 pockmarks contain small mounds at their centre being $0.1 \mathrm{~m}, 0.2 \mathrm{~m}$ and $0.4 \mathrm{~m}$ high respectively (Fig. 1112). P14, P15, P16 and P17 are all circular with a depth typically of $0.4 \mathrm{~m}$ to $1 \mathrm{~m}$ relative to the seabed. P15 also has a mound about $0.1 \mathrm{~m}$ in height at its centre. Maximum diameters vary from $54.5 \mathrm{~m}$ to $90 \mathrm{~m}$ across with the larger-diameter pockmarks tending to be deeper. 


\section{$\underline{\text { Queenie Corner }}$}

Analysis of the MBES data from the Queenie Corner MCZ suggests largely the same flat topography as seen in the WISMB with notable mound structures. The mounds occur in isolation as well as part of a linear chain, which is approximately $2 \mathrm{~km}$ in length (Fig. 1213). They exhibit a maximum relief of $1 \mathrm{~m}$ compared to the regular seabed (Fig. 1213). Backscatter data from these mounds also indicate higher reflectance compared to the surrounding sediments (Fig. 1213).

A single Pinger line from the Queenie Corner site revealed acoustic turbidity, indicating shallow gas, at its western end, coinciding with the mounds observed on MBES data (Fig. 1213 and 14). The top of the acoustic turbidity occurs within $1 \mathrm{~m}$ of the seabed with clear evidence for gas chimneys reaching the seabed rooted from the acoustic turbid zone. The gas chimneys emanating from the acoustic turbid zone precisely underlie the mounds observed on the MBES data. Further east, we observe a sharp boundary of the turbidity zone which is interpreted as the gas front (Fig. 13B14B).

\section{DISCUSSION}

\section{Revised geological model with inferences on gas origin and controls on fluid migration}

Structural lineaments (i.e. faults) and the properties of Quaternary sediments in the Irish Sea play a significant role in fluid migration from deep seated hydrocarbon source rocks to the shallow subseafloor stratigraphic layers, and eventually in subsequent seepage at the seafloor. In this section we discuss an individual, revised geological model for the CFZ and WISMB to elucidate the potential origins for hydrocarbon fluidsthermogenic gas in both areas, and the pathways and controls-that would allow for the migration of such fluids to the sub-seabed and seafloor. This is not to suggest that there is no biogenic component to any shallowthe gas in these areas. The data presented demonstrates that a thermogenic source cannot be excluded, and it is accepted that mixing of sources can occur.

Codling Fault Zone (incl. Lambay Deep) 
Gas-prone source rocks have been proven throughout the Irish Sea with the most prolific being the gasprone Pennine Coal Measures Group and the oil-prone Bowland Shale Formation, both of Carboniferous age (Pharaoh et al., 2016). Within the study area, the Pennine Coal Measures Group has been proven in the 33/22-1 borehole on the southern margin of the Kish Bank Basin where 17 metres of coal were

These coal-bearing horizons are interpreted throughout the Kish Bank Basin and are observed as the high-amplitude reflectors visible beneath the Base-Permian Unconformity (Fig. 3). Analysis of vitrinite reflectance data at the 33/22-1 borehole indicates these gas-prone source rocks have reached the pressure and temperature conditions to generate gas at present-day, suggesting that these same horizons at deeper, down-dip positions have generated hydrocarbons (Thomas, 1978). The Bowland Shale Formation has not been encountered in the 33/22-1 borehole, where the Pennine Coal Measures Group sits unconformably upon Lower Palaeozoic metasediments, although erosional outliers may be preserved elsewhere in the study area.

In addition to the presence of gas-prone source rocks, several indicators of an active petroleum system have been encountered in the vicinity of the Kish Bank Basin, in the form of both liquid and gaseous hydrocarbons. Both the previously mentioned 33/22-1 borehole and the 33/17-1 borehole on the eastern margin of the Kish Bank Basin encountered residual oil, the former in Carboniferous sandstones and the latter in Triassic sandstones (Charterhouse, 1986; Thomas, 1978). The 33/22-1 borehole reported tentative oil-staining in Lower Pleistocene sands which may indicate the remigration of liquid hydrocarbons from within the bedrock to these shallow, unconsolidated sediments. Previous authors have also presented a proprietary seep dataset which shows the location of present-day oil seeps, with a strong correlation between the location of seeps and distribution of both large faults and where sourcerocks sub-crop at the seabed (e.g. Anderson, 2013; Dunford et al., 2001).

Remigration of hydrocarbons from the bedrock to the shallow seabed can be facilitated by recent tectonic activity, which creates fluid conduits in the form of faults, which either breach existing hydrocarbon accumulations at depth or allow hydrocarbons to migrate directly from source rocks to seabed sediments (Anka et al., 2012; Corcoran and Doré, 2002). In the study area, the Codling Fault Zone is the most recent tectonic feature, being a NNW-SSE trending strike-slip fault and offshore extension of the Newry and Camlough Faults of Northern Ireland (Fig. 1). Kilometre-scale dextral motion on the fault has been recorded by several previous studies (e.g. Dunford et al., 2001) with the most recent research indicating displacement of 8.7 kilometres, incorporating up to 2 kilometres of normal 
movement on the basin-bounding fault along the northern margin of the Kish Bank Basin (Anderson, 2013). The timing of this fault activity is poorly constrained due to the attenuated Cenozoic section preserved in the study area but has been inferred to have a component of both Paleocene and

Several observations from 2D multichannel seismic data recorded in this study correlate spatially with the location of the Codling Fault Zone. Within the confines of the Kish Bank Basin, amplitude brightening is observed above the fault zone within the Quaternary units, with a sharp western boundary directly above the trend of one of main fault splays and a more diffuse contact to the east (Fig. 3). Additionally, reverse polarity anomalies are observed in the Cenozoic section directly above the fault zone. While none of the available boreholes penetrate these anomalies, correlation with those seismic intervals along-strike indicate these sediments consist of poorly consolidated sandstones interbedded with thin lavers of mudstone (Charterhouse, 1986; Thomas, 1978).Theseand these anomalies may represent local charging of these sands with re-migrated gaseous hydrocarbons which have migrated up the main fault plane of the Codling Fault Zone (e.g.(e.g. Løseth et al., 2009).Other authors have presented proprietary single-channel seismic data from this area which supports this interpretation, such as reverse-polarity anomalies and flat spots reported by Dunford et al., (2001). However, these anomalies will remain a speculative interpretation until ground truthing is done by geochemical sampling.

Evidence for shallow gas is also observed in Quaternary sediments (i.e. the PF and SSF) from shallow, sub-bottom acoustic data in the Lambay Deep causing enhanced reflection (Fig. 8). The PF has also been observed to be gas-bearing in the CFZ (Van Landeghem et al., 2015). Whilst we infer a thermogenic origin for the gas/fluids in this area, a biogenic component cannot be discounted. Isotope analysis of MDAC at the CFZ SAC by O'Reilly et al. (2014) suggests possible mixing of biogenic and thermogenic sourced gas. Based on the present data, it is not possible to estimate the timescales for the migration of these fluids. The Croker Carbonate Slab SAC is located 12-15 kms NE of the CFZ SAC area (Fig. 1). Judd et al. (2019) place the formation of MDACs in the Croker Carbonate Slab SAC-at between $17 \mathrm{ka}$ BP to $5 \mathrm{ka}$ $\mathrm{BP}$, with evidence for present day gas seepage. The MDAC cements the PF, which is inferred as being deposited in a glaciomarine environment between approximately $20 \mathrm{ka}$ and $10 \mathrm{ka}$ BP (Judd et al., 2019). It is also assumed that, prior to the deposition of the PF as the ISIS retreated, gas accumulated beneath the ice sheet (Judd et al., 2019). Gas accumulations below ice-sheets has also been proposed for other locations globally during the Devensian (Crémière et al., 2016; Fichler et al., 2005; Portnov et al., 2016). This spatial correlation of seabed features with the Codling Fault Zone implies that at least a portion of 


\section{Fault Zone acting as the main conduit for the migration of hydrocarbon fluids to the shallow subsurface.}

\section{Western Irish Sea Mud Belt (including Queenie Corner)}

Shallow gas accumulations have been observed in the MF in the WISMB, acoustically blanking the layers below (Coughlan et al., 2019) (Fig. 10). Similar accumulations of shallow gas in the WISMB have previously been linked with a biogenic origin, given the organic rich nature of the MF sediments (Yuan et al., 1992). Stable isotope data in Woods et al. (2019) presents evidence for methane seeps in the WISMB during the Mid Holocene age (post $8.2 \mathrm{ka}$ ). Considering the Holocene age of the MF and the estimated volume of gas present (Supplementary Material; S2), it is difficult to envision a solely biogenic source. This study has provided credibleclear evidence of shallow gas accumulation directly above a PermoTriassic infilled basin with its boundaries defined by the graben-bounding faults (Fig. 3 and Fig. 1415). These faults, which were reactivated during the Cenozoic and are observed offsetting the Base-Cenozoic Unconformity, would provide pathways for fluid flow from the Carboniferous source rocks below (Fig. 1415). The gas is seen to be hosted in the PF, below the base of the MF (Fig. 10). This suggests upward fluid migration through the underlying CF (glacial outwash sediments) and UT member (subglacial till). Whilst the UT in the Irish Sea is often over-consolidated, it is highly heterogeneous comprising a range of sediment classes that would facilitate fluid migration through it (Fig. 1415) (Coughlan et al., 2019; Van Landeghem et al., 2015). The top of the shallow gas is typically within 10-12 m of the seabed-surface and has a sharp boundary with the surrounding non-gas bearing sediments (Fig. 10). Pockmarks P14, P15, P16 and P17 were found to coincide with the lateral extent of underlying shallow gas accumulation, previously identified by Coughlan et al. (2019) (Fig. 9 and Fig. 1516). Episodic or continuous migration of this shallow gas accumulation to the seafloor would allow for fluid seepage at the seafloor, and the formation of features such as mounds and pockmarks, which will be discussed in more detail in the next section. Pockmarks occurring outside this accumulation of shallow gas form a strong, linear trend coincident with the prognosed extension of the Codling Fault Zone (Fig. 15), implying that fluid migrating from deeper source rocks along the main fault of CFZ possibly seep out from these pockmarks.16).

\section{Formation mechanisms of seep-related seafloor features}

We can classify seep-related seafloor morphological features observed in this study into two different types: mounds and pockmarks (Fig. 1516). Mounds can be further classified into mounds formed from 
MDACs and mounds formed due to mud-diapirism. Mounds described here in association withfrom the CFZ have collectively been described extensively in the literature as carbonate mounds formed from MDACs (Judd et al., 2019; O'Reilly et al., 2014; Van Landeghem et al., 2015). Alternatively, the mound located within Lambay Deep was described by Croker et al. (2005) as the Lambay Deep Mud Diapir (LDMD). Judd and Hovland (2007) defined a mud diapir as a sediment structure that has risen through a sediment sequence due to upward migrating fluids, piercing or deforming younger sediments. Mud diapirs can be recognised on seismic profiles as an acoustically amorphous piercement structure, as documented in the East China Sea (Xing et al., 2016), SW Taiwan (Chen et al., 2014), and the Mediterranean Ridge (Camerlenghi et al., 1992). In this section we focus on the formation mechanisms of the remaining seabed features in the WISMB, which are poorly understood in an Irish Sea context.

The pockmarks identified in this study are concentrated in the western part of the WISMB (Fig. 1516). Within this set of pockmarks (P1-P17) there are two different morphologies: pockmarks with a central mound and pockmarks without a central mound. All the pockmarks are located in an area of sandy-mud to muddy-sand according to the British Geological Survey DigSBS250 database (Fig. 1516). This differentiates them from pockmarks previously documented by Yuan et al. (1992), which were located in areas dominated by mud class sediments and were related to a zone of "acoustically turbid sediments" (ATZ) (Fig. 1516). Yuan et al. (1992) offers no explanation for the mechanism for their formation, although Croker et al. (2005) does highlight the requirement of clay- to silt-grade substrate for the formation of pockmarks. The fluids escaping from these pockmarks could either be biogenic- or thermogenic-sourced or of mixed origin. We further suggest that pore-water escape from the shallow glacimarine deposits could have also led to the formation of pockmarks, as suggested in other glacimarine settings (Harrington, 1985; Roy et al., 2019), however, pore-water escape would not support the formation of mounds within pockmarks.

Low-relief seabed mounds are found in Queenie Corner in the eastern part of the WISMB, which is characterised by sandy-mud seafloor sediments (Fig. 1516). Mounds mapped by Croker et al. (2005) occur in areas of mud and sandy mud (Fig. 1516). The near surface sediments in the WISMB are often under-consolidated, and so likely to be highly permeable (Coughlan et al., 2019; Mellet et al., 2015), which is unsuitable for the mechanism of formation proposed by Croker et al. (2005). In this study, described mounds and pockmarks are located in distinct areas and separated from each other. 
The distribution of these seep-related seafloor morphological features varies over differing seafloor sediment types, which indicatestherefore, requires differing formation mechanisms. Based on previous studies (Brothers et al., 2011; Crémière et al., 2018; Hammer et al., 2009; Hovland, 2002; Loher et al.,

Formatted: List Paragraph, Numbered + Level: $1+$ Numbering Style: i, ii, iii, ... + Start at: 1 + Alignment: Right + Aligned at: $0.63 \mathrm{~cm}+$ Indent at: $1.27 \mathrm{~cm}$

\section{The formation of central mounds within pockmarks in sediments with a sand component}

Initially fluid seepage at a relatively flat seafloor facilitates the development of microbial mats and an initial MDAC crust, which reduces the seepage rate at that the location (Fig. 16A 17A; Stage 1). Over time, this MDAC crust develops further, forming a consolidated seal at the seafloor (Fig. 16A 17A; Stage 2). A combination of seepage of fluids from, and bottom currents at, the seafloor around the mounds preferentially erodes the surrounding un-cemented seafloor sediments, partially exposing the MDAC crust (Fig. 16A 17A; Stage 3). Further seepage of fluids around the perimeter of the carbonate crust along with reworking and winnowing of sediments finally exposes the mound completely, which resembles a mound at the centre of a pockmark (Fig. 16A.17A; Stage 4). This is in agreement with the formation mechanism of carbonate mounds within pockmarks on a relatively flat seabed whereby a combination of fluid seepage and bottom currents erode the surrounding un-cemented seafloor sediments, partially exposing the mound in the centre of the pockmarks as has been suggested by Crémière et al. (2018). Similar carbonate crusts have been observed within pockmarks in the Harstad Basin in the Barents Sea (Crémière et al., 2018) and offshore Norway (Hovland et al., 2010), where several satellite pockmarks surrounding the 'mother pockmark' have been documented with a carbonate mound in the centre.

\section{The formation of seabed mounds, leading to pockmarks in muddy sediments}

Initially, prolonged seepage of methane gas at the seafloor leads to the formation of thin fragments of MDAC, followed by cementation of these thin MDAC fragments just beneath the seabed (Fig. 16B 17B; Stage 1). The thin MDAC crust beneath the seabed acts as an impermeable seal at the seabed sediment- 
water interface and redirectsdiverges fluid seepage around the MDAC crust perimeter (Fig. 16B 17B;

Stage 2). Gas starts to accumulate and build up pore-pressure beneath the crust, while also increasing theas well as leads to increase in pore-volume. The build-up of pore pressure and increase of pore volume within the unconsolidated sediments underlying the MDAC crust is facilitated by the combined effect of upward fluid migration and sealing capacities of mud-rich sediments and the MDAC crust. The sealing effect of the MDAC crust, along with the buoyant force of the upward migrating gas and increase in pore-volume, results in the bulging outward of the unconsolidated sediments and the MDAC crust (Fig. 16B 17B; Stage 3). At this point, the MDAC crust has been modified to a carbonate mound due to the outward bulging of the sediments underneath, such as the mounds at Queenie Corner (Fig. 1314). The gradual increase in the buoyant force of the gas further leads to the formation of fractures within the deformed MDAC mound, to the point when the MDAC mound ruptures and collapses under its own weight after the underlying pressurised gas has dissipated (Fig. 16B 17B; Stage 4). The collapsed mound resembles a crater-like depression like a pockmark. A single grab sample taken from the area of seafloor mounds in the southwestern section of Queenie Corner revealed cemented muds, with a strong odour, which would suggest hardened substrates caused by oxidation of methane forming carbonate precipitates (Supplementary Material; S3). However, this hypothesis assumes that the initial MDAC crust formation is thin enough to be deformed by the increase in pore pressure and volume due to the upward migrating fluids.

\section{Data interpretation and geological model limitations}

The identification, characterisation and assessment of geohazards such as shallow gas, fluid flow and seepage involves a multidisciplinary approach utilising a range of site investigation techniques

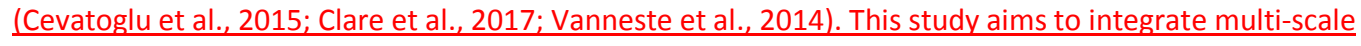
geophysical datasets in order to develop a geological framework to study potential fluid migration pathways from deeper stratigraphy or source rocks to shallow gas accumulations, and thereafter seepage at seafloor in the Irish Sea. Characterising and describing shallow gas acoustic features on shallow seismic data in particular depends on the acquisition system and frequencies used (Tóth et al., 2014). The shallow sub-bottom data used to characterise shallow sub-seabed features were gathered as part of regional surveys, without the express intention of studying shallow gas and fluid flow. The systems used to gather shallow sub-bottom data (i.e. sparker and pinger) transmit a signal within a frequency range of $0.5-4 \mathrm{kHz}$, which can be attenuated through scattering by fluid bubbles in gas 
charged sediments, the result of which is acoustic turbidity and blanking (Tóth et al., 2014). Both these phenomena are recognised in this study (Fig. 10) and are common at depth in such areas of mud to sandy mud on single-channel datasets (e.g. Laier and Jensen, 2007). As a result, only the top of the gas front is identified on shallow sub-bottom data, and there is ambiguity with regards to the depth of shallow gas and details of the underlying geology. However, low-frequency 2D-multichannel seismic provides information on underlying bedrock geology and tectonics. Ultimately, some studies show amplitude versus offset (AVO) analysis on 2D-multichannel seismic data to further affirm the presence of gas in the sediments (e.g. Kim et al., 2020)

At the seafloor, geomorphological features synonymous with fluid migration and seepage can be mapped using multibeam echosounder (e.g. Roelofse et al., 2020). In this study pockmarks have been identified, characterised and discussed within the context of fluid migration and seepage. However, there is a current lack of geochemical data from these pockmarks to ascertain the nature of fluids seeping from them. Analysis of cores taken in the vicinity of the pockmarks in the WISMB and the LDMD discussed here proved inconclusive in terms of determining the composition of sub-surface fluids due to a lack of depth penetration (O'Reilly, S. pers. Comms.). As this study has identified several areas within the northern Irish Sea where there is compelling evidence for the presence of gas in the shallow subsurface, we anticipate future research cruises will acquire sediment and pore-water samples to confirm the nature of origin or fluids seeping from these locations.

Implications of shallow gas and fluid seepage

The presence of gas accumulations in shallow sub-surface sediments can have engineering implications for the construction of offshore infrastructure and is considered a geohazard within the hydrocarbon and maritime industry (Evans, 2011; Hovland et al., 2002; Sun et al., 2017) as well as for renewable energy developments (Society for Underwater Technology, 2005). When gas occurs in solution in the pore-water, or free gas-filled voids between sediment grains, it can affect the compressibility of the sediment and negatively influence the engineering properties (Sills and Wheeler, 1992; Sultan et al., 2012). Where fluid seeps to the seafloor, it can impact the ground-conditions by: (i) forming a hard surface (i.e. MDAC), which may be difficult to pile or penetrate, or; (ii) causing changes in seabed 
structures. This study, inter alia, has mapped a widespread occurrence of shallow gas throughout the tectonic settings (Fig. 1 and 1516). More research is required to better understand the migration of fluids along proposed fault-routes, their sealing versus leaking capabilities, and the true nature and timing of the seeping fluids. At the very least, it is possible to anticipate where certain shallow gas and fluid escape structures may be encountered based on regional geology and mitigating site investigation techniques planned accordingly.

Studies have shown that MDAC harbours different benthic communities to surrounding sediments in the Irish Sea: whether this is due to the formation of complex three-dimensional reef-like structures in otherwise fairly homogeneous sedimentary habitats, thereby allowing colonisation by taxa common on hard rocky substrates, or due to the unique characteristics of MDAC which are as yet unclear (Judd et al., 2019; Noble-James et al., 2020). Pockmarks have been shown to harbour exclusive fauna in the North Sea (Webb et al., 2009), characterised by species with endosymbiotic sulphur-oxidising bacteria, as well as the structures providing shelter for specific fish species (Dando, 2001). (Dando, 2010) reviewed 62 shallow-water hydrothermal vent and cold seep sites and found that obligate species are rare at such sites, however higher species diversity was often found in the immediate vicinity of seeps often due to the heterogeneity of the bathymetrytopography, compared with surrounding more homogeneous areas. As yet, the pockmarks and seabed doming in this study have not had targeted biological sampling, but at Queenie Corner cemented sediment was retrieved by Day-grab from one seabed dome area with faunal excavation of the cemented sediment by bivalves and gastropods (Supplementary Material; S3). Whether the fauna in such structures is unique compared to surrounding sedimentary areas would require further investigation; however, substrata-boring fauna could be viewed as a functionally significant component of the local ecosystem (Noble-James et al., 2020). An understanding of this, coupled with accurate mapping of the extent and potential ecological connectivity of such features throughout the Irish Sea, is required to underpin effective management of these habitats.

\section{CONCLUSIONS AND FUTURE WORK}

High-resolution geophysical datasets from the Irish Sea reveal sub-seabed shallow gas accumulations in Quaternary sediments and a range of seafloor expressions of fluid seepage. Based on the integrated geophysical investigation of seafloor geomorphologies, shallow sub-surface sediments and deeper 
geological and tectonic features, this study generated a geological framework from which the following can be made summarised $\underset{\Xi}{-}$

In both the Codling Fault Zone and Western Irish Sea Mud Belt, there is compelling evidence linking shallow gas accumulation within Quaternary sediments with major structural lineaments (i.e. faults) in the bedrock geology. These faults can act as pathways for hydrocarbon fluids to migrate from deeply seated potential-source rocks to shallow stratigraphic layers. This supports earlier geochemical studies which found a thermogenic component to the shallow gas and seafloor seepage features in both these areas.

In the Western Irish Sea Mud Belt, both pockmarks and seabed mounds were recorded in areas of mud with a varying sand component. Pockmarks display two morphologies consisting of regular, circular types and pockmarks with a central mound, typically less than $0.5 \mathrm{~m}$ in relief. Pockmark centres often exhibit high backscatter reflectance values suggesting some degree of sediment consolidation due to the formation of MDAC. Mounds are typically $1 \mathrm{~m}$ in height above the regular seabed and are associated with gas chimneys rooted to an underlying shallow gas accumulation. These mounds, and surrounding seabed, exhibit high back backscatter reflectance values, again, suggesting the formation of MDAC. This is supported by a grab sample from a mound containing cemented, MDAC-like material.

We propose two mechanisms for the formation of pockmarks; one in muddy seafloor settings with a sand component, which accounted for the formation of a central mound, and one for the formation of thin MDAC mounds as pre-cursors to pockmarks in muddy seafloor settings.

Based on our findings, we make the following concluding statements and recommendations for future work:

- The revised geological models for the Codling Fault Zone and Western Irish Sea Mud Belt allow for a better understanding of the role of existing and re-activated faults as a potential pathway for fluid (e.g. gas) migration from kilometre-scale depth to the shallow sub-seabed. In future, this will help quantify the contribution of thermogenic-sourcederigin gas to ongoing shallow sub-seabed gas accumulation and seafloor seepage in these areas. Geochemical analysis of targeted seabed seepage and shallow gas accumulation locations from the Western Irish Sea Mud Belt is required to constrain the origin of shallow gas definitively and is a proposed area of further work. 
- To validate the model linking the creation of MDAC to pockmark formation, repeat survey data over the mounds at Queenie Corner is required to record their evolution over time.

- The presence of shallow gas accumulations in the Western Irish Sea Mud Belt, along with gas chimneys and mounds, suggests that fluid seepage at the seafloor is an on-going process. This has significant implications for seabed infrastructure development and seabed ecological and conservation efforts. Based on the results of this study and models presented, our understanding of the geological controls on fluid migration and seafloor seepage is greatly improved, making it increasingly possible to predict the extent of shallow gas and location of certain gas seepage structures in the Irish Sea. Future data collection surveys (e.g. INFOMAR) will further improve this understanding.

- To better constrain gas content and extent of gas front in areas of acoustic blanking, we recommend the acquisition of multichannel seismic data and the application of AVO analysis.

- Ground-truthing and further geotechnical analysis of Quaternary sediments is required to better understand how fluids migrate through, and are hosted in, these sediments.

- Biological data available from the Western Irish Sea Mud Belt pockmarks and mounds are limited in determining the range of biodiversity at these sites at present. Epibenthic surveys consisting of drop-frame or towed camera platforms or ship-based grab sampling are typically unable to spatially target and sample chemoautotrophic communities, so it is recommended that ROV techniques are used for such purposes.

\section{Acknowledgements}

This research is funded in part by a research grant from Science Foundation Ireland (SFI) under Grant Number 13/RC/2092 and is co-funded under the European Regional Development Fund, and by the Petroleum Infrastructure Programme (PIP) and its member companies. SR is funded by the Irish Research Council Government of Ireland Postdoctoral Fellow Award (GOIPD/2018/17). The authors would like to thank the Petroleum Affairs Division (PAD) of the Department of Communications, Climate Action and Environment (DCCAE), Ireland, for providing access to released borehole, seismic and potential field datasets. The authors would also like to thank Schlumberger for providing academic licenses of Petrel to University College Dublin. We are grateful to IHS Markit for providing the academic 
licence for the KINGDOM software package to iCRAG. This paper contains Irish Public Sector Data

Institute, Northern Ireland) for releasing the MBES data for Queenie Corner, and for support during the AFBI surveys. The pinger line shown was acquired as part of NERC project NE/H02431/1. The authors acknowledge Rosie Jebb (GSI) and Andy Trafford (UCD) for assistance processing MBES and sub-bottom profile data respectively. The authors also acknowledge the crew and scientists onboard all surveys listed for their work, co-operation and skill in collecting the data. The authors would like to thank 3

\section{References}

Anderson, H., 2013. The origin and nature of Cenozoic faulting in north-east Ireland and the Irish Sea. University College Dublin.

Andreassen, K., Nilssen, E.G., Ødegaard, C.M., 2007. Analysis of shallow gas and fluid migration within the Plio-Pleistocene sedimentary succession of the SW Barents Sea continental margin using 3D seismic data. Geo-Marine Lett. 27, 155-171. https://doi.org/10.1007/s00367-007-0071-5

Anka, Z., Berndt, C., Gay, A., 2012. Hydrocarbon leakage through focused fluid flow systems in continental margins. Mar. Geol. 332-334, 1-3. https://doi.org/https://doi.org/10.1016/j.margeo.2012.10.012

Brothers, L.L., Kelley, J.T., Belknap, D.F., Barnhardt, W.A., Andrews, B.D., Maynard, M.L., 2011. More than a century of bathymetric observations and present-day shallow sediment characterization in Belfast Bay, Maine, USA: implications for pockmark field longevity. Geo-Marine Lett. 31, 237-248. https://doi.org/10.1007/s00367-011-0228-0

Bunce, J., 2018. The history of exploration and development of the Liverpool Bay fields and the East Irish Sea Basin. Hist. Eur. Oil Gas Ind. https://doi.org/10.1144/SP465.6

Camerlenghi, A., Cita, M.B., Hieke, W., Ricchiuto, T., 1992. Geological evidence for mud diapirism on the Mediterranean Ridge accretionary complex. Earth Planet. Sci. Lett. 109, 493-504. https://doi.org/https://doi.org/10.1016/0012-821X(92)90109-9

Charterhouse, 1986. Well 33/17-1 Final Geological Report. Charterhouse Ireland Exploration Company.

Chen, S.-C., Hsu, S.-K., Wang, Y., Chung, S.-H., Chen, P.-C., Tsai, C.-H., Liu, C.-S., Lin, H.-S., Lee, Y.-W., 2014. Distribution and characters of the mud diapirs and mud volcanoes off southwest Taiwan. J. Asian Earth Sci. 92, 201-214. https://doi.org/https://doi.org/10.1016/j.jseaes.2013.10.009 Clements, A., Service, M., 2016. Alternative Marine Conservation Zones in Irish Sea mud habitat: Assessment of habitat extent and condition at "Queenie corner" and assessment of fishing activity at potential MCZ sites. Report to Seafish Northern Ireland Advisory Committee.

Cole, D., Stewart, S.A., Cartwright, J.A., 2000. Giant irregular pockmark craters in the Palaeogene of the Outer Moray Firth Basin, UK North Sea. Mar. Pet. Geol. 17, 563-577. https://doi.org/https://doi.org/10.1016/S0264-8172(00)00013-1

Corcoran, D. V, Doré, A.G., 2002. Depressurization of hydrocarbon-bearing reservoirs in exhumed basin settings: evidence from Atlantic margin and borderland basins. Geol. Soc. London, Spec. Publ. 196, 457 LP - 483. https://doi.org/10.1144/GSL.SP.2002.196.01.25

Coughlan, M., Wheeler, A.J., Dorschel, B., Long, M., Doherty, P., Mörz, T., 2019. Stratigraphic model of 
the Quaternary sediments of the Western Irish Sea Mud Belt from core, geotechnical and acoustic data. Geo-Marine Lett. 39, 223-237.

Crémière, A., Chand, S., Sahy, D., Thorsnes, T., Martma, T., Noble, S.R., Pedersen, J.H., Brunstad, H., Lepland, A., 2018. Structural controls on seepage of thermogenic and microbial methane since the last glacial maximum in the Harstad Basin, southwest Barents Sea. Mar. Pet. Geol. 98, 569-581. https://doi.org/https://doi.org/10.1016/j.marpetgeo.2018.07.010

Crémière, A., Lepland, A., Chand, S., Sahy, D., Condon, D.J., Noble, S.R., Martma, T., Thorsnes, T., Sauer, S., Brunstad, H., 2016. Timescales of methane seepage on the Norwegian margin following collapse of the Scandinavian Ice Sheet. Nat. Commun. 7, 11509. https://doi.org/10.1038/ncomms11509

Croker, P.F., Kozachenko, M., Wheeler, A.J., 2005. Gas-Related Seabed Structures in the Western Irish Sea (IRL-SEA6). January 2005, Tech Rep Strategic Environmental Assessment of the Irish Sea (SEA6), UK Department of Trade and Industry.

Dando, P.R., 2010. Biological communities at marine shallow-water vent and seep sites, in: Kiel, S. (Ed.), Vent and Seep Biota: Aspects from Microbes to Ecosystems. Springer Netherlands, Dordrecht, pp. 333-378. https://doi.org/10.1007/978-90-481-9572-5_11

Dando, P.R., 2001. A review of pockmarks in the UK part of the North Sea, with particular respect to their biology. Strategic Environmental Assessment - SEA2. Technical Report 001 - Pockmarks.

Dondurur, D., Çifçi, G., Drahor, M.G., Coşkun, S., 2011. Acoustic evidence of shallow gas accumulations and active pockmarks in the İzmir Gulf, Aegean sea. Mar. Pet. Geol. 28, 1505-1516. https://doi.org/10.1016/j.marpetgeo.2011.05.001

Dunford, G.M., Dancer, P.N., Long, K.D., 2001. Hydrocarbon potential of the Kish Bank Basin: integration within a regional model for the Greater Irish Sea Basin. Geol. Soc. London, Spec. Publ. 188, 135 LP 154. https://doi.org/10.1144/GSL.SP.2001.188.01.07

Ergün, M., Dondurur, D., Çifçi, G., 2002. Acoustic evidence for shallow gas accumulations in the sediments of the Eastern Black Sea. Terra Nov. 14, 313-320. https://doi.org/10.1046/j.13653121.2002.00434.x

Evans, T.G., 2011. A systematic approach to offshore engineering for multiple-project developments in geohazardous areas, in: Frontiers in Offshore Geotechnics II - Proceedings of the 2nd International Symposium on Frontiers in Offshore Geotechnics. pp. 3-32.

Fichler, C., Henriksen, S., Rueslaatten, H., Hovland, M., 2005. North Sea Quaternary morphology from seismic and magnetic data: indications for gas hydrates during glaciation? Pet. Geosci. 11, 331 LP 337. https://doi.org/10.1144/1354-079304-635

Floodpage, J., Newman, P., White, J., 2001. Hydrocarbon prospectivity in the Irish Sea area: insights from recent exploration of the Central Irish Sea, Peel and Solway basins. Geol. Soc. London, Spec. Publ. 188, 107 LP - 134. https://doi.org/10.1144/GSL.SP.2001.188.01.06

Games, K.P., 2001. Evidence of shallow gas above the Connemara oil accumulation, Block 26/28, Porcupine Basin, in: Haughton, P.W., Corcoran, D. V (Eds.), The Petroleum Exploration of Ireland's Offshore Basins. The Geological Society of London, Special Publications, London, pp. 361-373. https://doi.org/10.1144/GSL.SP.2001.188.01.21

Hammer, $\varnothing$., Webb, K.E., Depreiter, D., 2009. Numerical simulation of upwelling currents in pockmarks, and data from the Inner Oslofjord, Norway. Geo-Marine Lett. 29, 269-275. https://doi.org/10.1007/s00367-009-0140-z

Hovland, M., 2002. On the self-sealing nature of marine seeps. Cont. Shelf Res. 22, 2387-2394. https://doi.org/https://doi.org/10.1016/S0278-4343(02)00063-8

Hovland, M., Curzi, P. V, 1989. Gas seepage and assumed mud diapirism in the Italian central Adriatic Sea. Mar. Pet. Geol. 6, 161-169. https://doi.org/https://doi.org/10.1016/0264-8172(89)90019-6 Hovland, M., Gardner, J. V, Judd, A.G., 2002. The significance of pockmarks to understanding fluid flow processes and geohazards. Geofluids 2, 127-136. https://doi.org/10.1046/j.1468- 
Hovland, M., Heggland, R., De Vries, M.H., Tjelta, T.I., 2010. Unit-pockmarks and their potential significance for predicting fluid flow. Mar. Pet. Geol. 27, 1190-1199. https://doi.org/10.1016/j.marpetgeo.2010.02.005

Hovland, M., Judd, A.G., 1992. The global production of methane from shallow submarine sources. Cont. Shelf Res. 12, 1231-1238. https://doi.org/10.1016/0278-4343(92)90082-U

Hovland, M., Judd, A.G., 1988. Seabed Pockmarks and Seepages. Graham and Trotman, London.

Jackson, D.I., Jackson, A.A., Evans, D., Wingfield, R.T.R., Barnes, R.P., Arthur, M.J., 1995. United Kingdom offshore regional report: the geology of the Irish Sea. British Geological Survey, London.

Jackson, D.I., Mullholland, P., 1993. Tectonic and stratigraphic aspects of the East Irish Sea Basin and adjacent areas: contrasts in their post-Carboniferous structural styles. Geol. Soc. London, Pet. Geol. Conf. Ser. 4, 791 LP - 808. https://doi.org/10.1144/0040791

Jordan, S.F., O’Reilly, S.S., Praeg, D., Dove, D., Facchin, L., Romeo, R., Szpak, M., Monteys, X., Murphy, B.T., Scott, G., McCarron, S.S., Kelleher, B.P., 2019. Geophysical and geochemical analysis of shallow gas and an associated pockmark field in Bantry Bay, Co. Cork, Ireland. Estuar. Coast. Shelf Sci. 225, 106232. https://doi.org/10.1016/j.ecss.2019.05.014

Judd, A., Noble-James, T., Golding, N., Eggett, A., Diesing, M., Clare, D., Silburn, B., Duncan, G., Field, L., Milodowski, A., 2019. The Croker Carbonate Slabs: extensive methane-derived authigenic carbonate in the Irish Sea-nature, origin, longevity and environmental significance. Geo-Marine Lett. https://doi.org/10.1007/s00367-019-00584-0

Judd, A.G., Hovland, M., 2007. Seabed Fluid Flow, the Impact on Geology, Biology, and the Marine Environment. Cambridge University Press.

Judd, A.G., Hovland, M., 1992. The evidence of shallow gas in marine sediments. Cont. Shelf Res. 12, 1081-1095.

Karisiddaiah, S.M., Veerayya, M., 1994. Methane-bearing shallow gas-charged sediments in the eastern Arabian Sea: a probable source for greenhouse gas. Cont. Shelf Res. 14, 1361-1370. https://doi.org/https://doi.org/10.1016/0278-4343(94)90053-1

Kiel, S., 2010. The vent and seep biota, in: Landman, N.H., Harries, P. (Eds.), Topics in Geobiology. Springer, Germany, p. 487.

Koch, S., Berndt, C., Bialas, J., Haeckel, M., Crutchley, G., Papenberg, C., Klaeschen, D., Greinert, J., 2015. Gas-controlled seafloor doming. Geology 43, 571-574. https://doi.org/10.1130/G36596.1

Loher, M., Marcon, Y., Pape, T., Römer, M., Wintersteller, P., dos Santos Ferreira, C., Praeg, D., Torres, M., Sahling, H., Bohrmann, G., 2018. Seafloor sealing, doming, and collapse associated with gas seeps and authigenic carbonate structures at Venere mud volcano, Central Mediterranean. Deep. Res. Part I Oceanogr. Res. Pap. 137, 76-96. https://doi.org/10.1016/j.dsr.2018.04.006

Løseth, H., Gading, M., Wensaas, L., 2009. Hydrocarbon leakage interpreted on seismic data. Mar. Pet. Geol. 26, 1304-1319. https://doi.org/https://doi.org/10.1016/j.marpetgeo.2008.09.008

Mazumdar, A., Peketi, A., Dewangan, P., Badesab, F., Ramprasad, T., Ramana, M. V., Patil, D.J., Dayal, A., 2009. Shallow gas charged sediments off the Indian west coast: Genesis and distribution. Mar. Geol. 267, 71-85. https://doi.org/10.1016/j.margeo.2009.09.005

Mellet, C., Long, D., Carter, G., Chiverell, R., Van Landeghem, K., 2015. Geology of the seabed and shallow subsurface: The Irish Sea. British Geological Survey Commissioned Report, CR/15/057. $52 \mathrm{pp}$.

National Parks and Wildlife, 2015. Codling Fault Zone SAC Site Synopsis. Republic of Ireland.

Newman, P.J., 1999. The geology and hydrocarbon potential of the Peel and Solway Basins, East Irish Sea. J. Pet. Geol. 22, 305-324. https://doi.org/10.1111/j.1747-5457.1999.tb00989.x

Noble-James, T., Judd, A., Diesing, M., Clare, D., Eggett, A., Silburn, B., Duncan, G., 2020. Monitoring shallow methane-derived authigenic carbonate: Insights from a UK Marine Protected Area. Aquat. 
O'Reilly, S.S., Hryniewicz, K., Little, C.T.S., Monteys, X., Szpak, M.T., Murphy, B.T., Jordan, S.F., Allen, C.C.R., Kelleher, B.P., 2014. Shallow water methane-derived authigenic carbonate mounds at the Codling Fault Zone, western Irish Sea. Mar. Geol. 357, 139-150. https://doi.org/10.1016/j.margeo.2014.08.007

Pharaoh, T.C., Smith, N.J.P., Kirk, K., Kimbell, G.S., Gent, C., Quinn, M., Monaghan, A.A., 2016. Palaeozoic Petroleum Systems of the Irish Sea Energy and Marine Geoscience Programme, British Geological Survey Commissioned Report.

Portnov, A., Vadakkepuliyambatta, S., Mienert, J., Hubbard, A., 2016. Ice-sheet-driven methane storage and release in the Arctic. Nat. Commun. 7, 10314. https://doi.org/10.1038/ncomms10314

Ramprasad, T., Dewangan, P., Ramana, M. V, Mazumdar, A., Karisiddaiah, S.M., Ramya, E.R., Sriram, G., 2011. Evidence of slumping/sliding in Krishna-Godavari offshore basin due to gas/fluid movements. Mar. Pet. Geol. 28, 1806-1816. https://doi.org/https://doi.org/10.1016/j.marpetgeo.2011.02.007

Rathburn, A.E., Levin, L.A., Held, Z., Lohmann, K.C., 2000. Benthic foraminifera associated with cold methane seeps on the northern California margin: Ecology and stable isotopic composition. Mar. Micropaleontol. 38, 247-266. https://doi.org/https://doi.org/10.1016/S0377-8398(00)00005-0

Roy, S., Hovland, M., Noormets, R., Olaussen, S., 2015. Seepage in Isfjorden and its tributary fjords, West Spitsbergen. Mar. Geol. 363, 146-159. https://doi.org/https://doi.org/10.1016/j.margeo.2015.02.003

Roy, S., Senger, K., Braathen, A., Noormets, R., Hovland, M., Olaussen, S., 2014. Fluid migration pathways to seafloor seepage in inner isfjorden and Adventfjorden, Svalbard. Nor. Geol. Tidsskr. 94, 99-199.

Sills, G.C., Wheeler, S.J., 1992. The significance of gas for offshore operations. Cont. Shelf Res. 12, 12391250.

Society for Underwater Technology, 2005. Guidance Notes on Site Investigations for Offshore Renewable, Guidance notes on site investigations for offshore renewable energy projects.

Sultan, N., de Gennaro, V., Puech, A., 2012. Mechanical behaviour of gas-charged marine plastic sediments. Geotechnique 62, 751-766. https://doi.org/10.1680/geot.12.0G.002

Sun, Q., Alves, T., Xie, X., He, J., Li, W., Ni, X., 2017. Free gas accumulations in basal shear zones of masstransport deposits (Pearl River Mouth Basin, South China Sea): An important geohazard on continental slope basins. Mar. Pet. Geol. 81, 17-32. https://doi.org/https://doi.org/10.1016/j.marpetgeo.2016.12.029

Sun, Q., Wu, S., Hovland, M., Luo, P., Lu, Y., Qu, T., 2011. The morphologies and genesis of megapockmarks near the Xisha Uplift, South China Sea. Mar. Pet. Geol. 28, 1146-1156. https://doi.org/https://doi.org/10.1016/j.marpetgeo.2011.03.003

Szpak, M.T., Monteys, X., O'Reilly, S., Simpson, A.J., Garcia, X., Evans, R.L., Allen, C.C.R., McNally, D.J., Courtier-Murias, D., Kelleher, B.P., 2012. Geophysical and geochemical survey of a large marine pockmark on the Malin Shelf, Ireland. Geochemistry, Geophys. Geosystems 13, 1-18. https://doi.org/10.1029/2011GC003787

Szpak, M.T., Monteys, X., O'Reilly, S.S., Lilley, M.K.S., Scott, G.A., Hart, K.M., McCarron, S.G., Kelleher, B.P., 2015. Occurrence, characteristics and formation mechanisms of methane generated micropockmarks in Dunmanus Bay, Ireland. Cont. Shelf Res. 103, 45-59. https://doi.org/10.1016/j.csr.2015.04.023

Thomas, I.W., 1978. Well 33/22-1 Completion Report. Amoco Ireland Exploration Company.

Van Landeghem, K.J.J., Niemann, H., Steinle, L.I., O'Reilly, S.S., Huws, D.G., Croker, P.F., 2015. Geological settings and seafloor morphodynamic evolution linked to methane seepage. Geo-Marine Lett. 35, 289-304. https://doi.org/10.1007/s00367-015-0407-5 
Ward, S.L., Neill, S.P., Landeghem, K.J.J. Van, Scourse, J.D., 2015. Classifying seabed sediment type using simulated tidal-induced bed shear stress. Mar. Geol. 367, 94-104. https://doi.org/10.1016/j.margeo.2015.05.010

Webb, K.E., Barnes, D.K.A., Plankea, S., 2009. Pockmarks: Refuges for marine benthic biodiversity. Limnol. Oceanogr. 54, 1776-1788. https://doi.org/10.4319/lo.2009.54.5.1776

Woods, M.A., Wilkinson, I.P., Leng, M.J., Riding, J.B., Vane, C.H., Lopes dos Santos, R.A., Kender, S., De Schepper, S., Hennissen, J.A.I., Ward, S.L., Gowing, C.J.B., Wilby, P.R., Nichols, M.D., Rochelle, C.A., 2019. Tracking Holocene palaeostratification and productivity changes in the Western Irish Sea: $A$ multi-proxy record. Palaeogeogr. Palaeoclimatol. Palaeoecol. 532, 109231. https://doi.org/https://doi.org/10.1016/j.palaeo.2019.06.004

Xing, J., Jiang, X., Li, D., 2016. Seismic study of the mud diapir structures in the Okinawa Trough. Geol. J. 51, 203-208. https://doi.org/10.1002/gj.2824

Yuan, F., Bennell, J.D., Davis, A.M., 1992. Acoustic and physical characteristics of gassy sediments in the western Irish Sea. Cont. Shelf Res. 12, 1121-1134.

\section{Figure Captions}

Figure 1 Overview of the location of study areas (A-D) within the Irish Sea along with 2D reflection seismic lines and borehole locations referred to in the text superimposed on previously mapped areas of sub-cropping Carboniferous rocks, Mesozoic sedimentary basins (both accessed from EMODNet) and structural lineaments (Anderson, 2013; Anderson et al., 2016). Also included are Special Areas of Conservation (SAC) and Marine Conservation Zones (MCZ) related to gas features and the extent of the Western Irish Sea Mud Belt. Please note that the Carboniferous potential source rock is present in the Permian-Triassic basins.

Figure 2 (A) Simplified lithostratigraphic column of the bedrock geology of the Western Irish Sea. (B) Simplified lithostratigraphic column of the Quaternary section discussed in this study.

Figure 3 2D multichannel seismic line E95IE18-03 and accompanying geoseismic interpretation. Image quality degrades significantly within the Codling Fault Zone due to a combination of structural complexity and shallow gas-related features. Inset: Several shallow gas related features are identified within the Codling Fault Zone, including seabed brightening with a sharp boundary above a major, nearseabed splay of the Codling Fault Zone, and reverse polarity anomalies with associated seismic blanking and signal dispersion.

Figure 4 2D multichannel seismic line IS-12 and accompanying geoseismic interpretation. The graben fill is predicted to be of Permian-Triassic sediment, similar to the stratigraphy of the along-strike Peel Basin. 
The faults bounding the graben are observed to offset the Base-Cenozoic Unconformity, indicating recent tectonic activity and representing possible fluid-migration pathways.

Figure 5 2D multichannel seismic line JSM92-30 and accompany geoseismic interpretation. Several minor faults are observed offsetting the Base-Cenozoic Unconformity in the Queenie Corner area.

Figure 6 Seabed mounds observed at the southern part of the study area (within the Codling Fault Zone) are interpreted as carbonate mounds which form as a result of prolonged seepage at the seafloor. Sediment waves are predominant in this region of the study area. A and B highlight the mound structures in close up (note different water depth scales for better visualization of the mounds). High backscatter is evident at these two locations. Refer to Fig. 1 for location.

Figure 7 (A) High-resolution bathymetric data illustrating seafloor morphology at Lambay Deep, along with (B) vertical profile across the $1 \mathrm{~km}$ wide depression. (C) Zoom-in of the bathymetric high which is characterized by high-backscatter (D). Refer to Fig. 1 for location.

Figure 8 Lambay Deep as imaged by sparker seismic data with interpreted units. Highlighted is the mound referred to as the Lambay Deep Mud Diapir (LDMD) and acoustic evidence for shallow gas (acoustic turbidity and enhanced reflections). ' $M$ ' denotes seabed multiple. Unit names are referenced from Figure 2. Yellow line is the top of UT (Upper Till member), blue line is top of PF (Prograded Facies), SSF is Surface Sands Formation. Red line denotes the edge of the LDMD. Dashed black line is the top of the shallow gas.

Figure 9 Depth to the top of the gas accumulation (interpreted on a grid of 2D sparker seismic lines shown in Fig. 1 of Coughlan et al., (2019), identified in the Western Irish Sea Mud Belt superimposed on water depth from MBES data. Highlighted are the pockmarks described in Supplementary Material, the location of seismic lines presented in Fig. 10 and the pockmarks presented in detail in Fig. 11.-and Fig. 12.

Figure 10 Sparker seismic lines highlighted in Fig. 9 from the WISMB with interpreted units. Also presented is evidence for shallow gas accumulation (enhanced reflection, acoustic turbidity, acoustic blanking). ' $\mathrm{M}$ ' denotes seabed multiple. Unit names are referenced from Figure 2 . Full black line 
indicates the top of bedrock. Yellow line is the top of UT (Upper Till member), green line is the top of CF 10

Figure 11Figure $11(\mathrm{~A})$ The largest irregular elongated pockmark (P12) is shown on high-resolution

bathymetric data. A smaller circular pockmark is located NE of P12. (B) High-backscatter at the centre of the pockmark is indicative of possible carbonate precipitates or coarse sediments due to prolonged seepage. (C) Bathymetric contour lines illuminated the rim of the irregular elongated pockmark (P12), string pockmarks at its centre and the surrounding seafloor morphology. Vertical profiles across the short and long-axis of the elongated pockmark (P12) illustrate the small depth change (1-1.2 m) across the P12 pockmark. Refer to Fig. 9 for location. WD: Water depth.

Figure 12 High-resolution bathymetric data illustrating (A) a central mound within pockmark P15, and (B) morphology of a circular pockmark P13 without a central mound along with their vertical profiles. (C) Central mounds within pockmarks P10 and P11, which are separated by approximately $1 \mathrm{~km}$. Refer to Fig. 9 for locations.

Figure 1213 High-resolution multibeam bathymetric data (top) and backscatter data (bottom) of the Queenie Corner area seafloor. Refer to Fig. 1 for location. A closer illustration of the seabed mound structures of various sizes and shapes (sub-circular to elongated) have been shown along with their vertical profiles.

Figure 1314 Pinger profile highlighted in Fig. 1213 from Queenie Corner illustrates acoustic evidence for shallow gas in the form of gas chimneys (a) and acoustic blanking (b). Seabed mounds are observed at the top of gas chimneys (a).

Figure 1415 Conceptual model proposed for fluid migration from deeper thermogenic source rocks via recently reactivated fault conduits to shallow gas-charged Quaternary sediments in the Western Irish Sea Mud Belt. Subsequently, some of the gas migrates upwards to the seafloor, leading to the formation of pockmarks (due to fluid seepage) and seabed mounds (due to increase of pressure and volume within sediment pores). 
Figure 1516 Overview map of shallow gas accumulations and fluid seepage features identified in this study along with similar features identified from other referenced studies. This information is superimposed on the British Geological Survey DigSBS250 database, which maps seabed sediment distribution. according to the Folk Classification, in the Irish Sea at a scale of 1:250,000. Some pockmarks from this study are seen to form above a mapped shallow gas accumulation with mud-dominated sediments, generally pockmarks (this study) are concentrated in areas with a sandier component. Seabed mound features in this study were found in areas where the seabed sediment is muddominated.

Figure 1617 Conceptual models proposed for $(A)$ the formation of mounds at the centre of pockmarks in sand-rich sediments and (B) seabed mounds in mud-rich sediments as a precursors to collapsed pockmarks, , adapted from previous studies (Hovland, 2002; Crémière et al. 2018; Loher et al. 2018).

\section{Table Captions}

Table 1 List of surveys from which data were used in this study. 


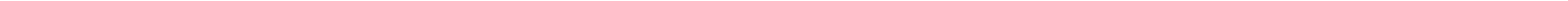




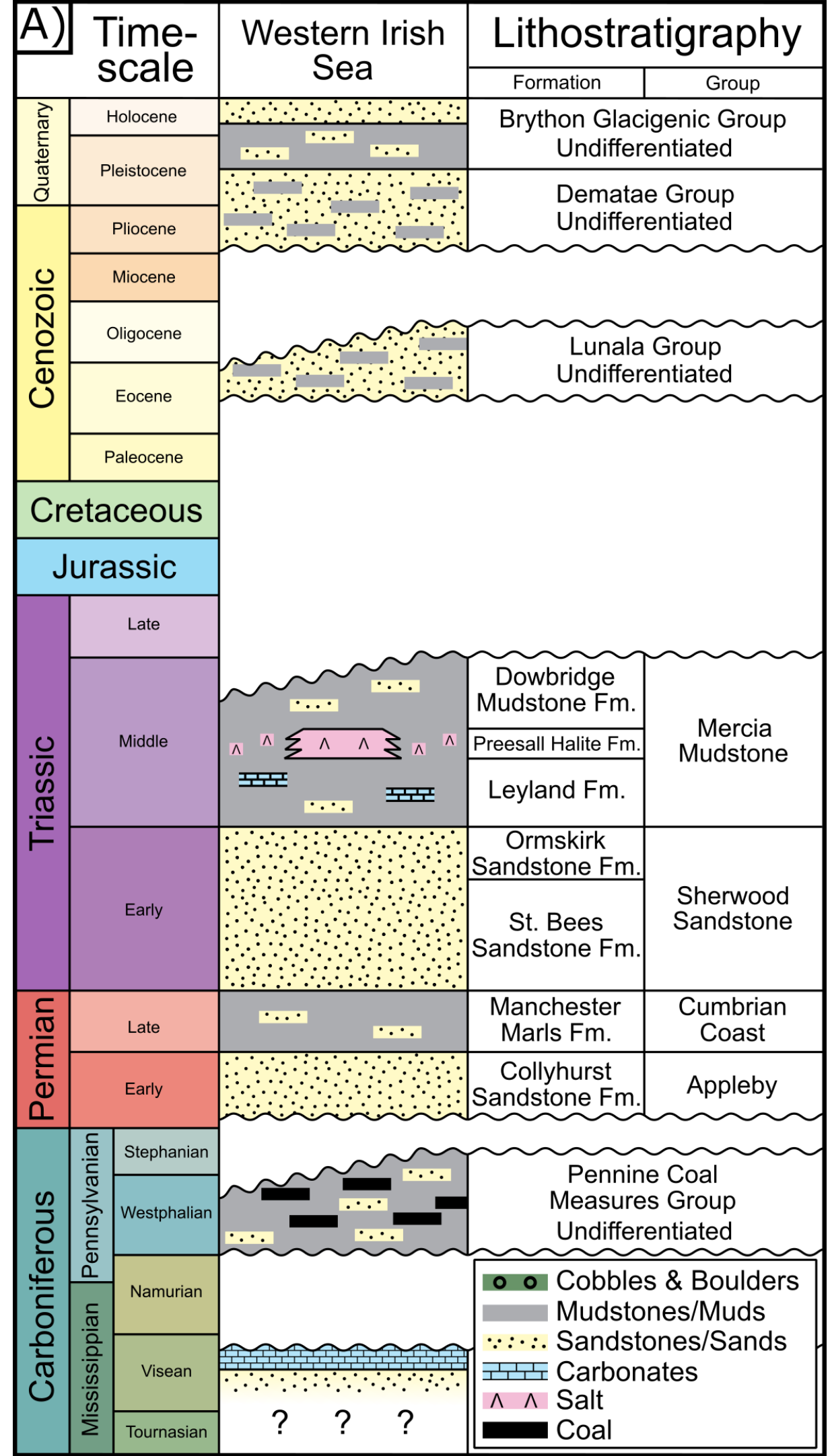

\begin{tabular}{|c|c|c|c|c|c|}
\hline B) & Time- & Western Irish & Lithostra & tigraph & \\
\hline & scale & & Member & Formation & Gp. \\
\hline & & & $\begin{array}{c}\text { Seabed } \\
\text { Depression Mbr. }\end{array}$ & & \\
\hline 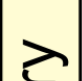 & & & $\begin{array}{c}\text { Sediment Layer } 1 \\
\text { Upper Mbr. }\end{array}$ & $\begin{array}{c}\text { Surface } \\
\text { Sands Fm. }\end{array}$ & س \\
\hline ত্র & Holocene & 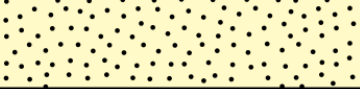 & $\begin{array}{c}\text { Sediment Layer } 2 \\
\text { Lower Mbr. }\end{array}$ & & 을 \\
\hline$\stackrel{\square}{ \pm}$ & & $\therefore \quad \ldots, \quad \cdots$ & $\begin{array}{c}\text { Mud } \\
\text { Facies Mbr. }\end{array}$ & & Q \\
\hline$\frac{\text { Td }}{2}$ & & 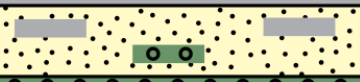 & $\begin{array}{l}\text { Prograded } \\
\text { Facies Mbr. }\end{array}$ & $\begin{array}{l}\text { Western } \\
\text { Irish }\end{array}$ & 离. \\
\hline 0 & Pleisto & $\begin{array}{l}0 \\
0\end{array}$ & $\begin{array}{c}\text { Chaotic } \\
\text { Facies Mbr. }\end{array}$ & & 需. \\
\hline & & $\begin{array}{ccccc}0 & 0 & 0 & \cdots \\
\ldots & 0 & 0\end{array}$ & $\begin{array}{l}\text { Upper } \\
\text { Till Mbr. }\end{array}$ & $\begin{array}{l}\text { Cardigan } \\
\text { Bay Fm. }\end{array}$ & \\
\hline
\end{tabular}



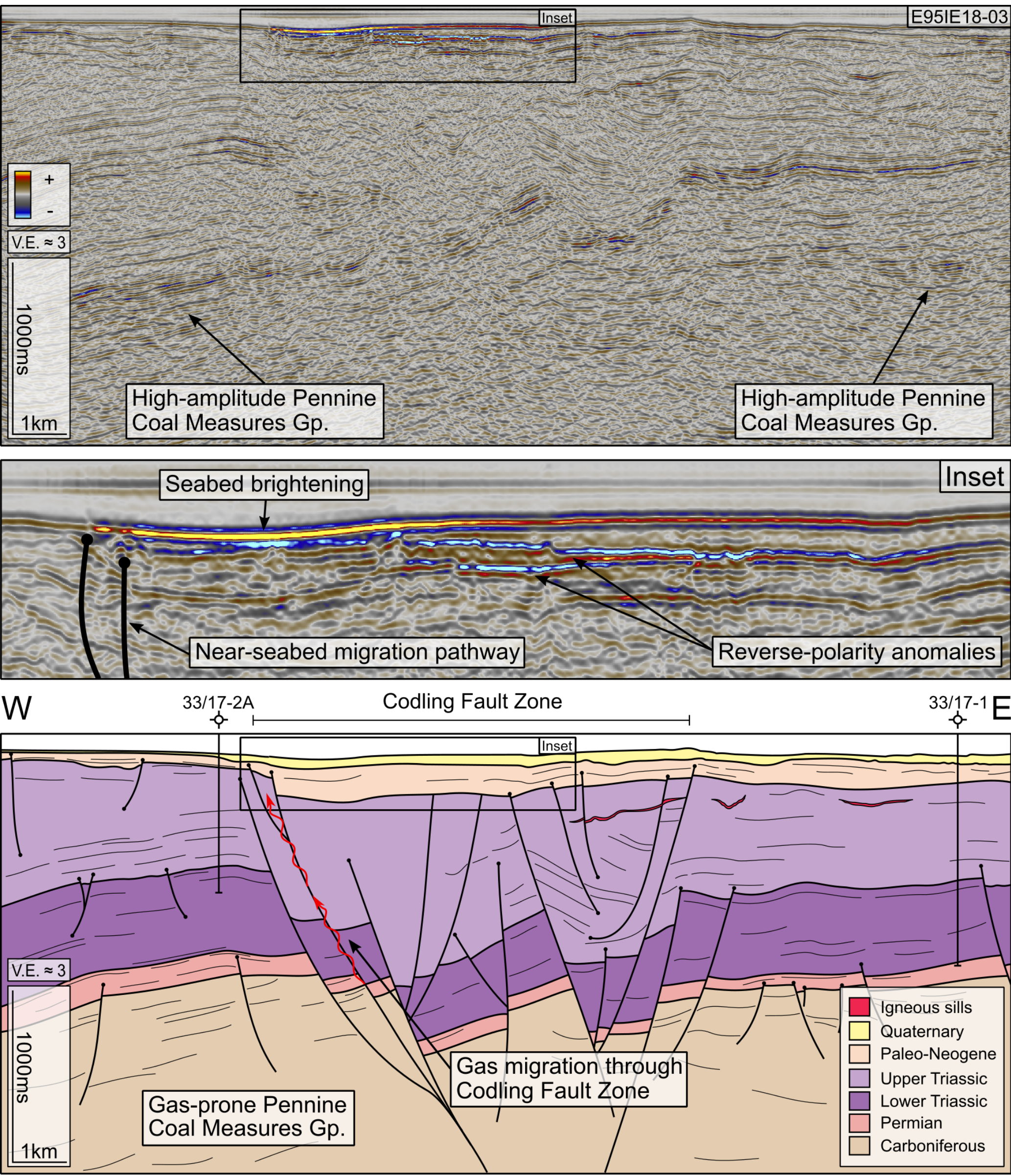

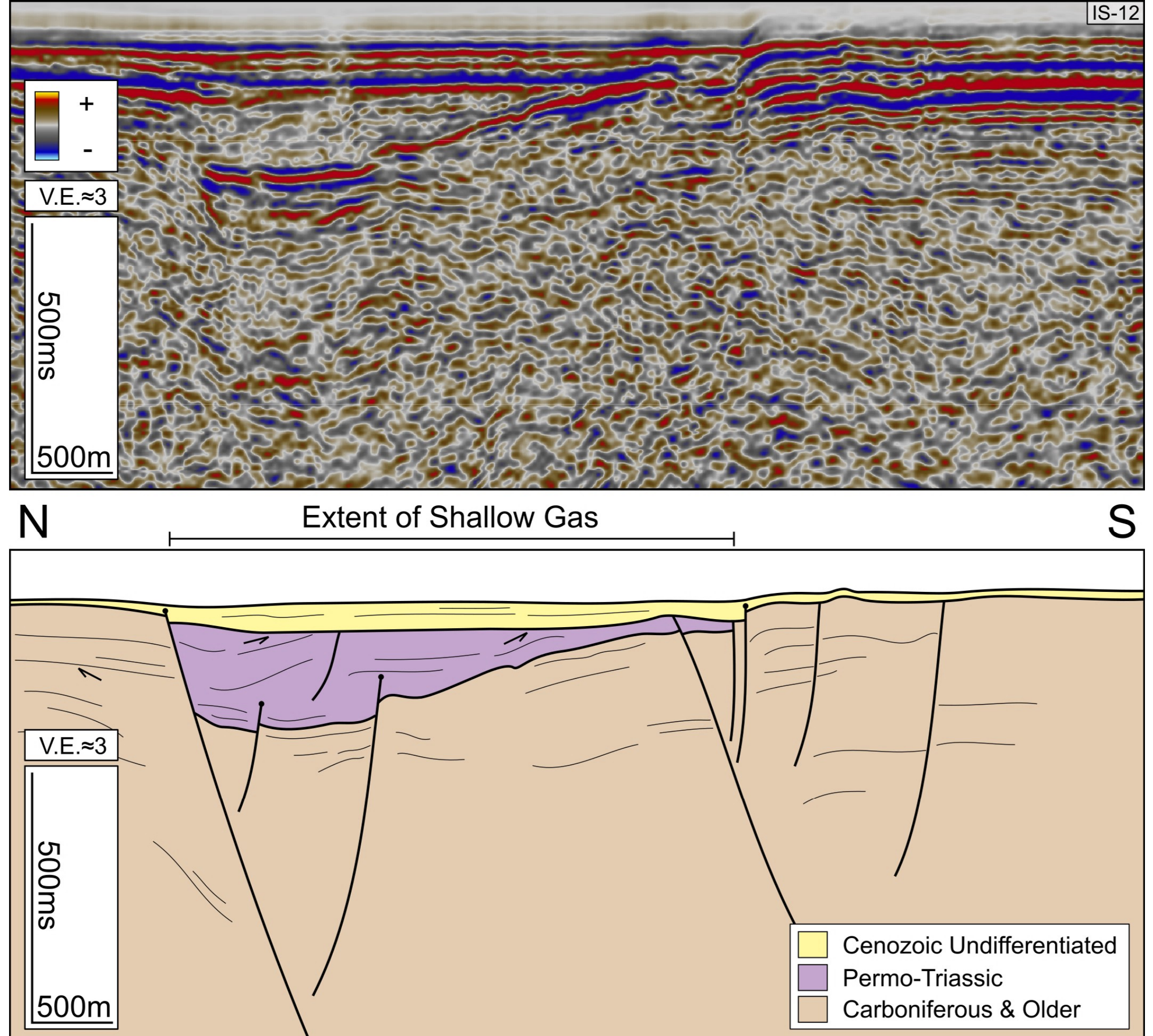


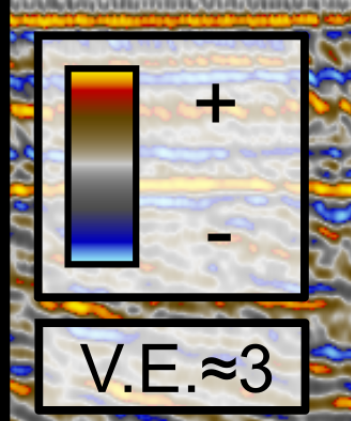

$\mid N$
0
3
5
$500 \mathrm{~m}$

NW $\quad$ SE
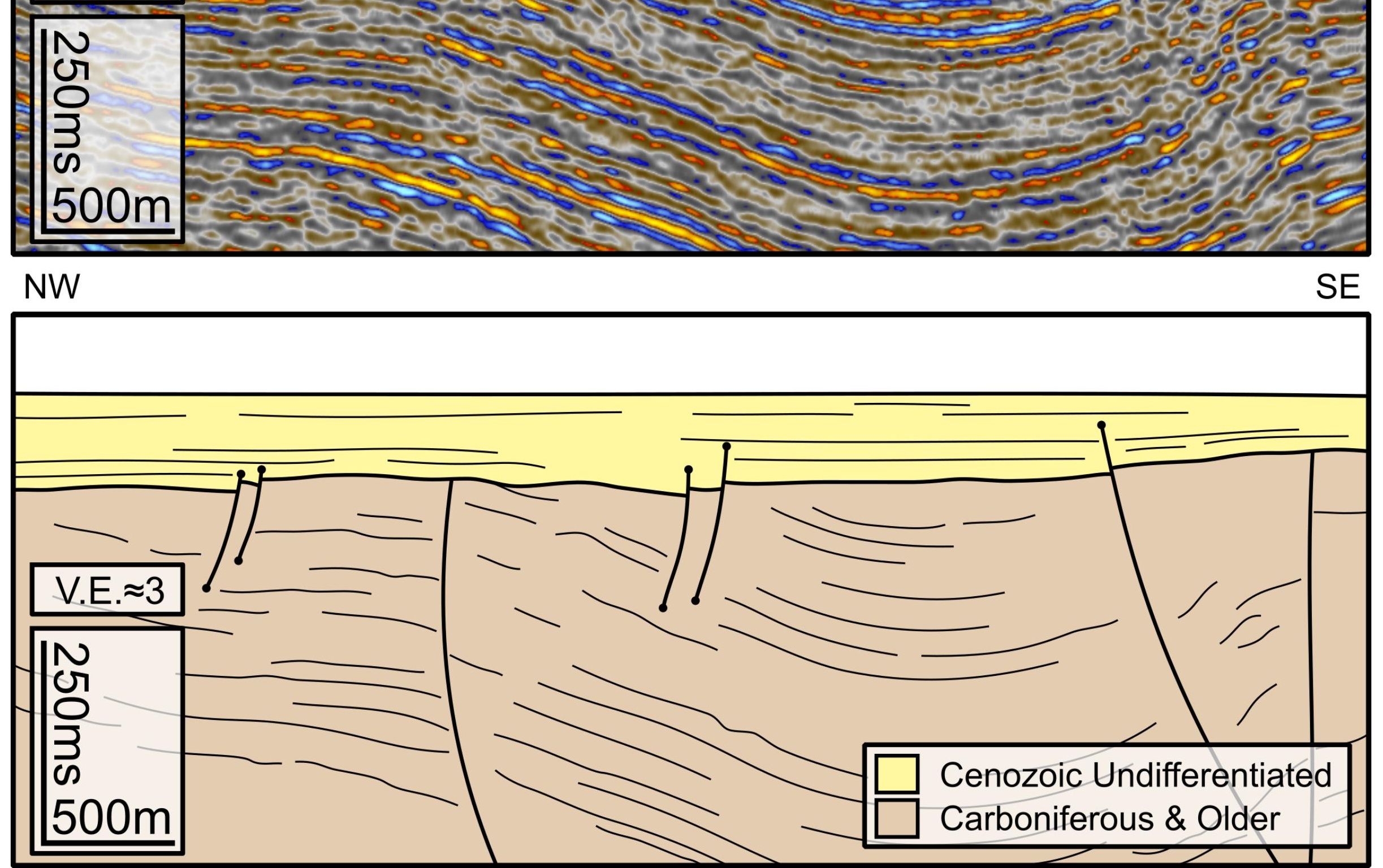

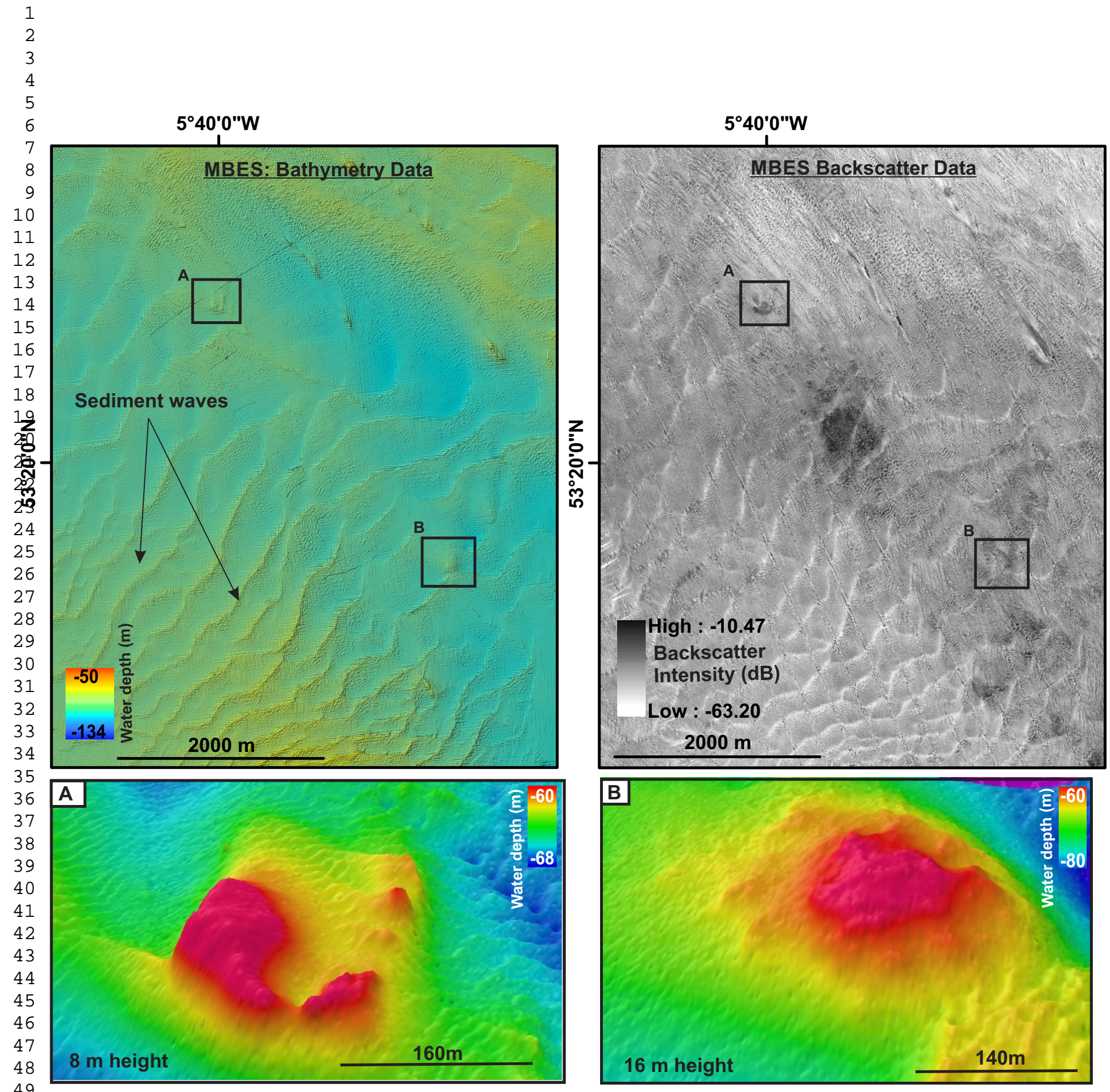
1
2
3
4
5
6
7

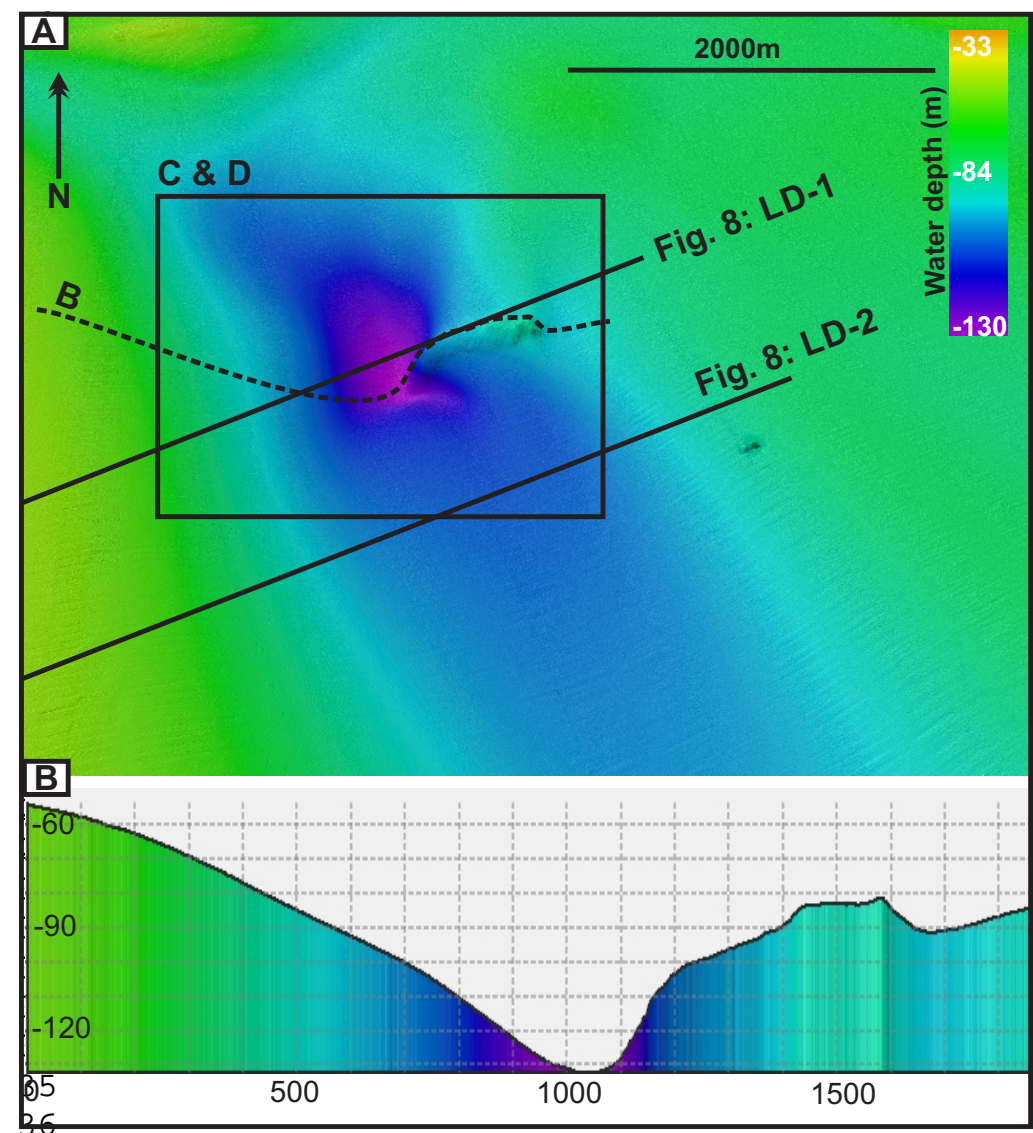

37

38

39

40

41

42

43

44

45

46

47

48

49

50

51

52

53

54

55

56

57

58

59

60

61

62

63

64

65 $5^{\circ} 48^{\prime} 0^{\prime \prime W}$

$5^{\circ} 47^{\prime} 0$ "W
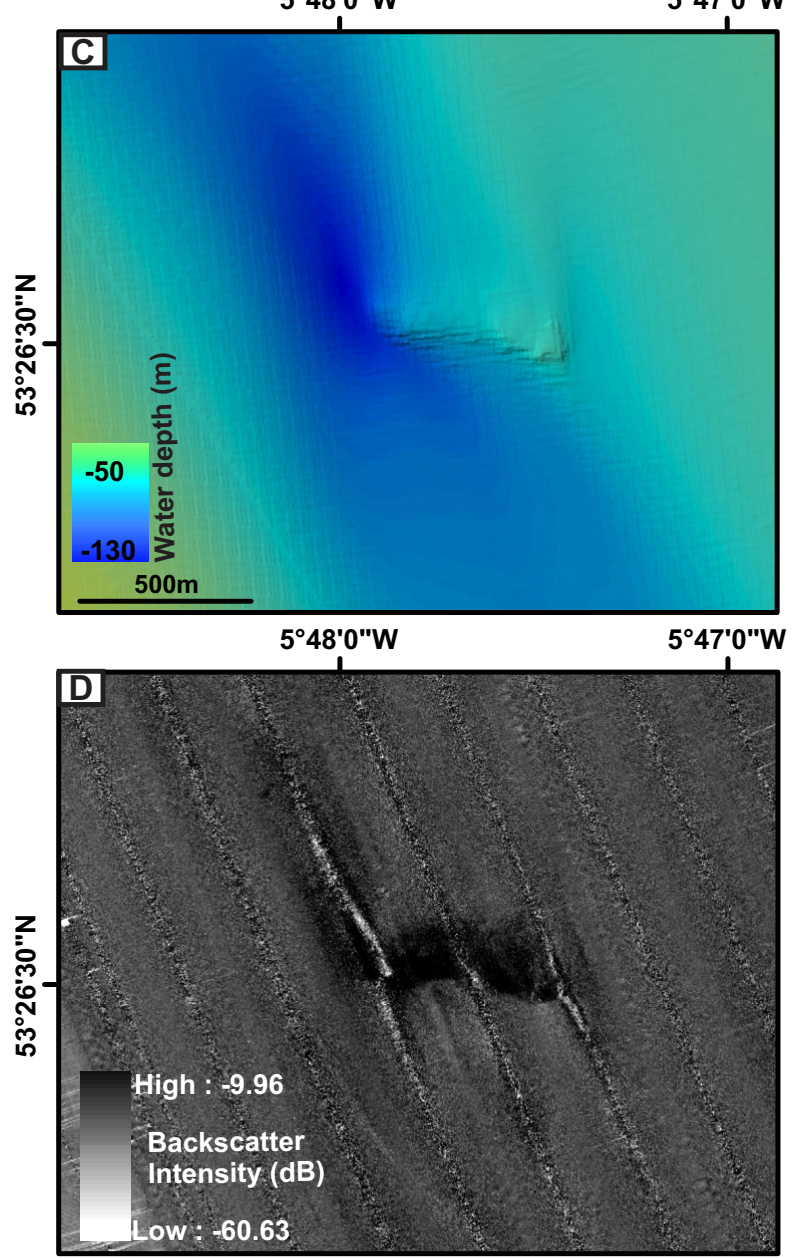


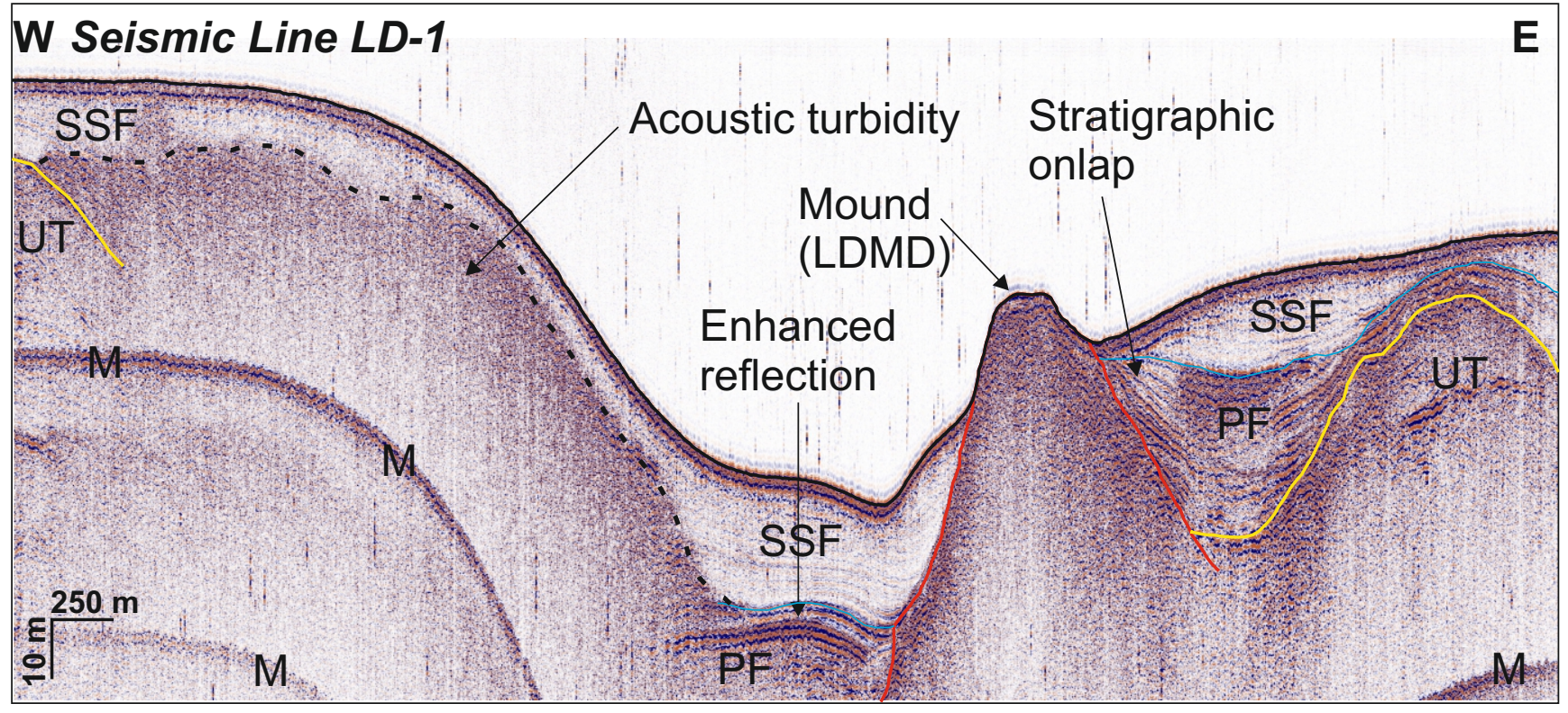

\section{W Seismic Line LD-2}

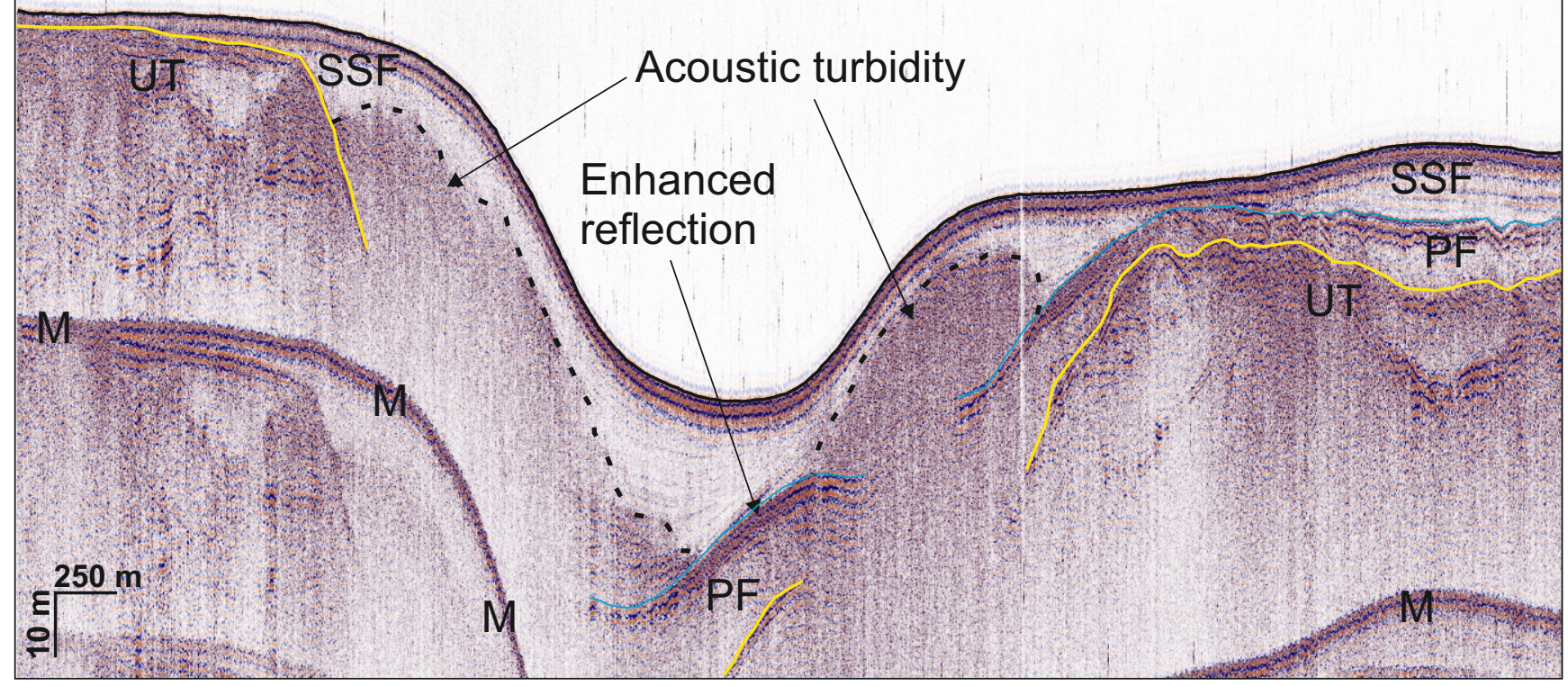




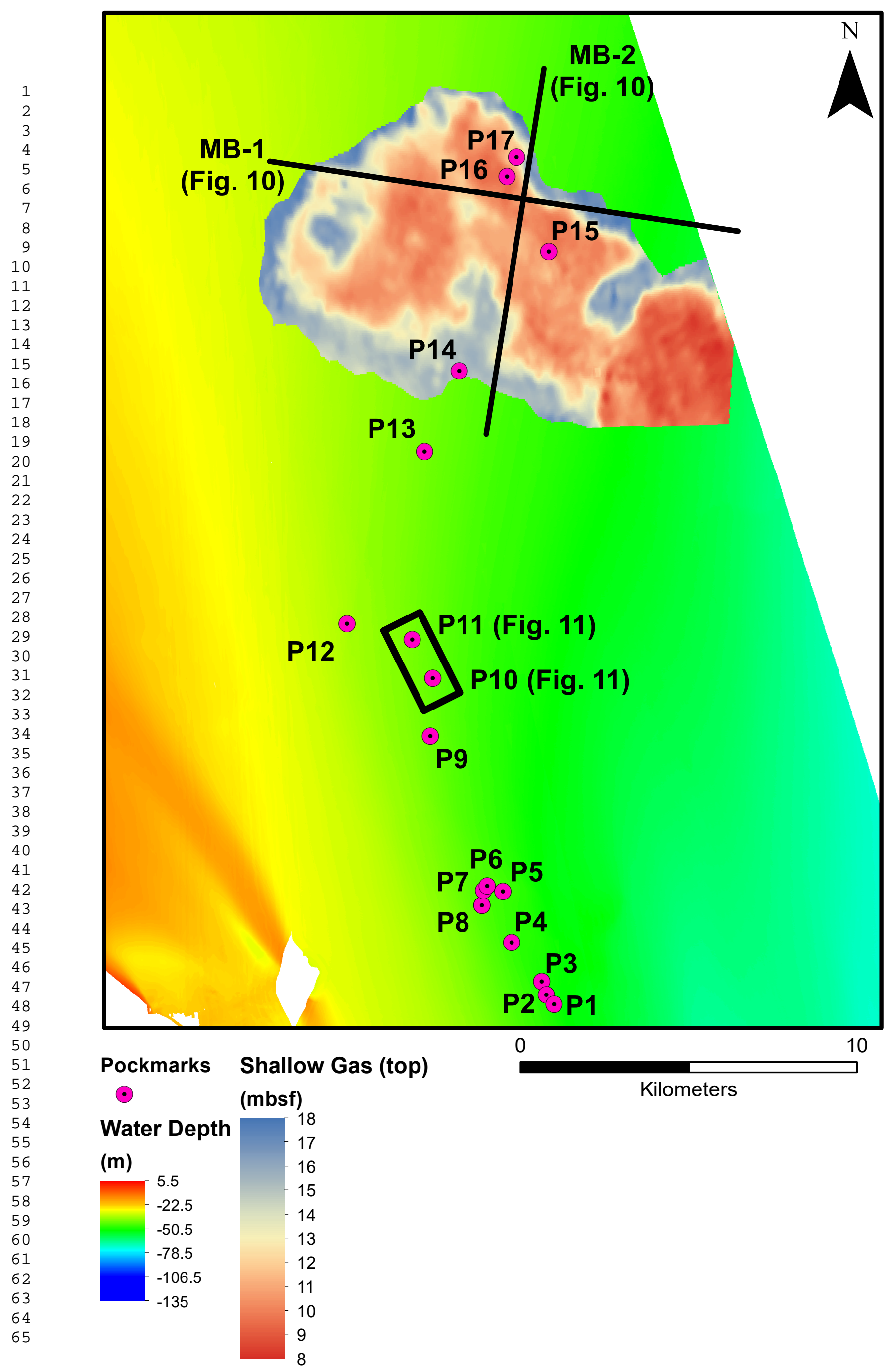




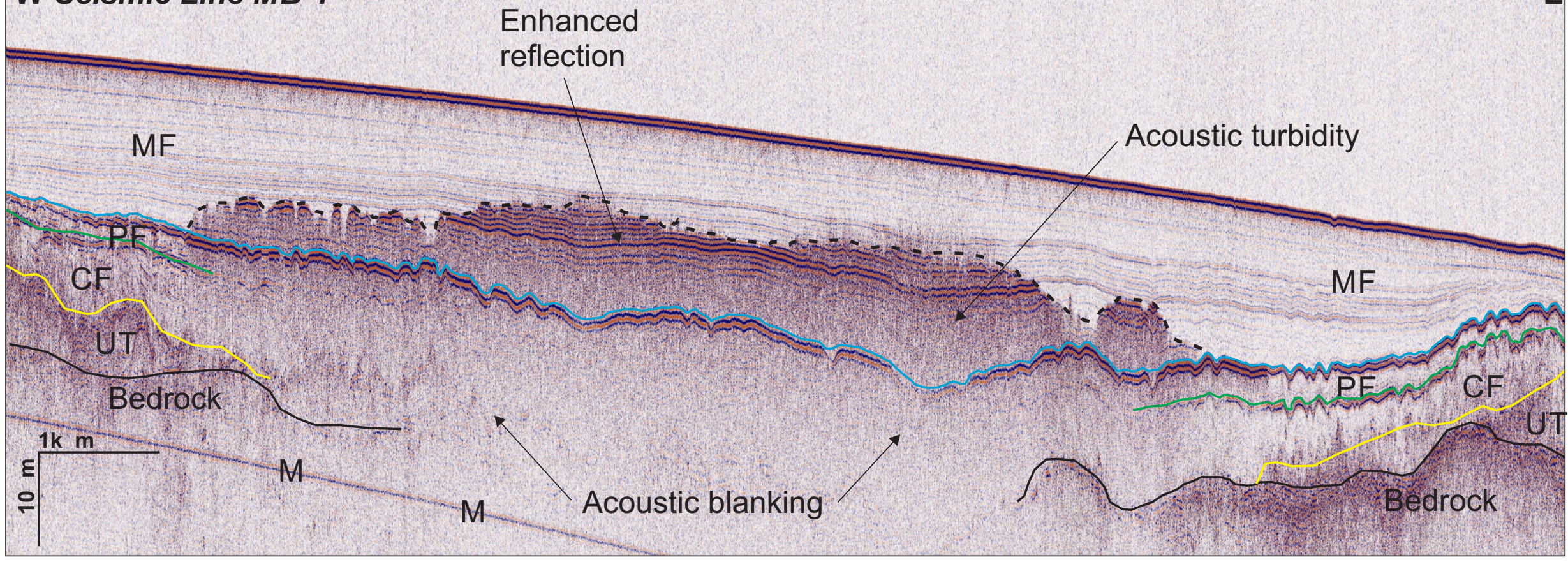

\section{W Seismic Line MB-2}

E

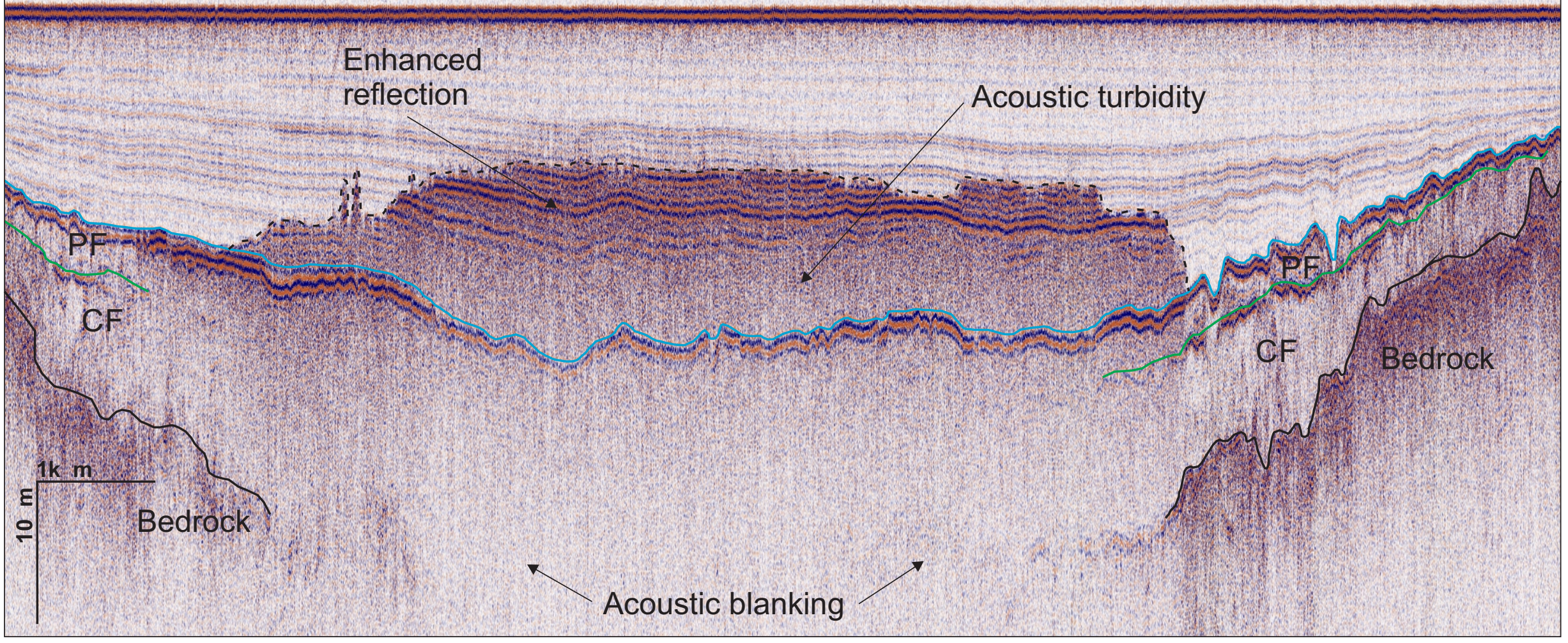


Figure 11

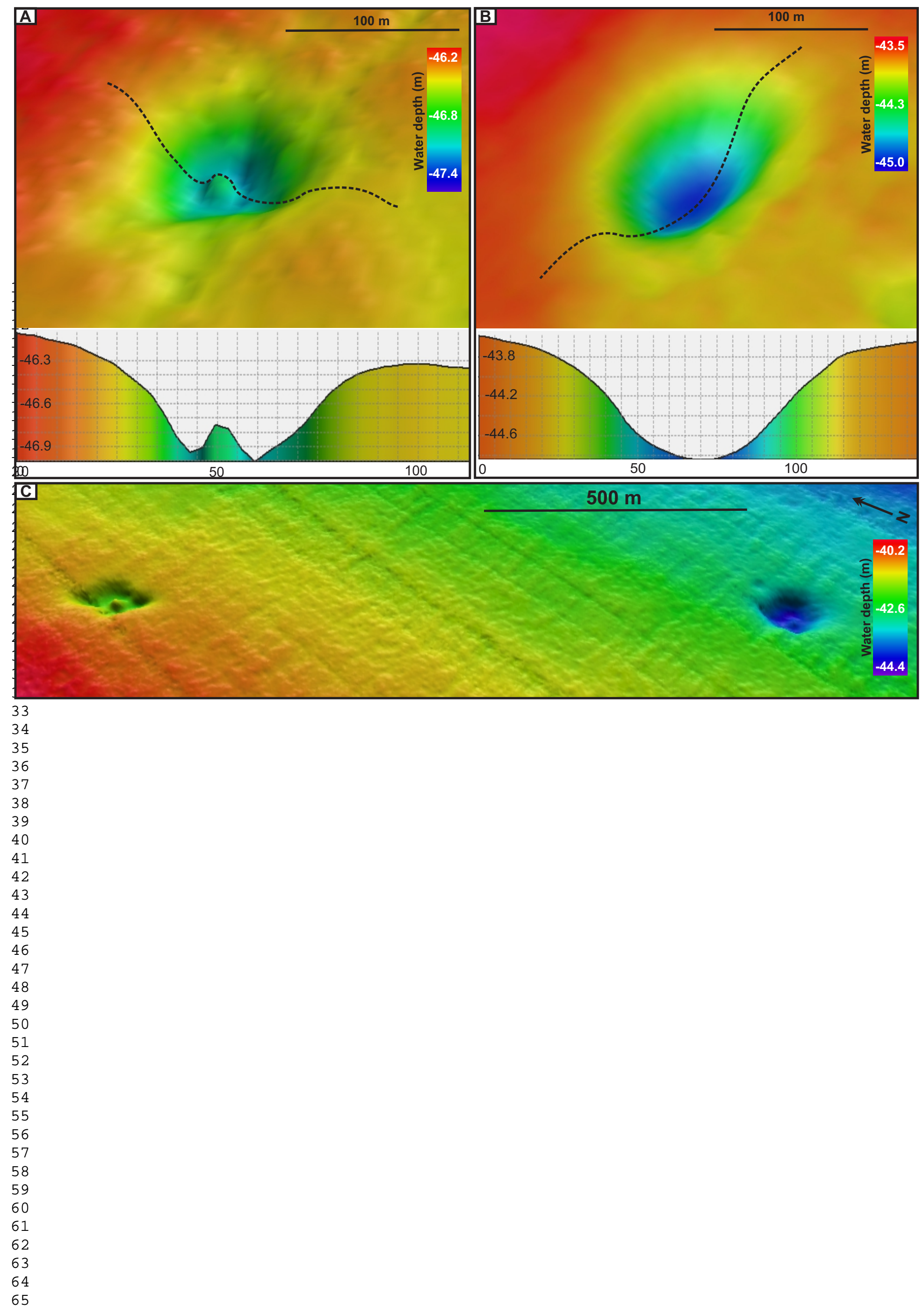



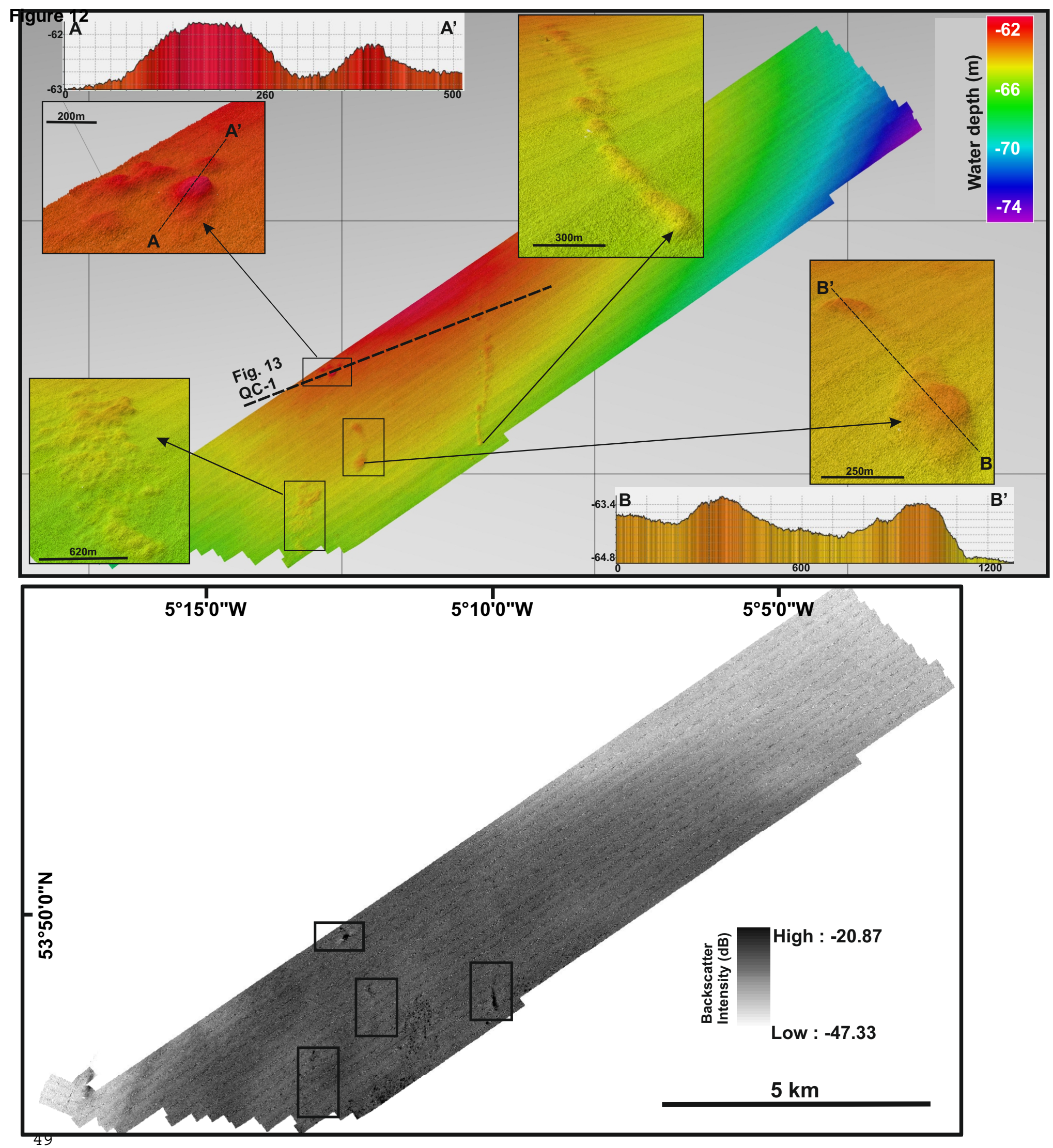
Figure 13

1
2
3
4
5
6
7
8
9
10
11
12

$$
\mathbf{W}^{13}
$$

$W_{1}^{2}$ Seismic Line QC-1
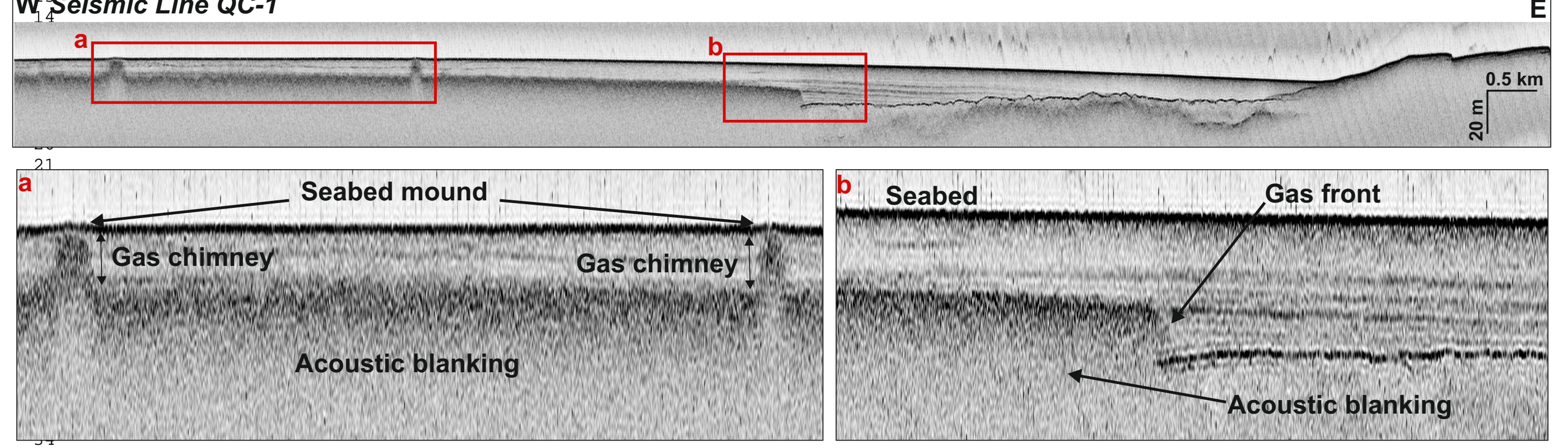

35
36
37
38
39
40
41
42
43
44
45
46
47
48
49

9

10

11

Acoustic blanking

9


Figure 14

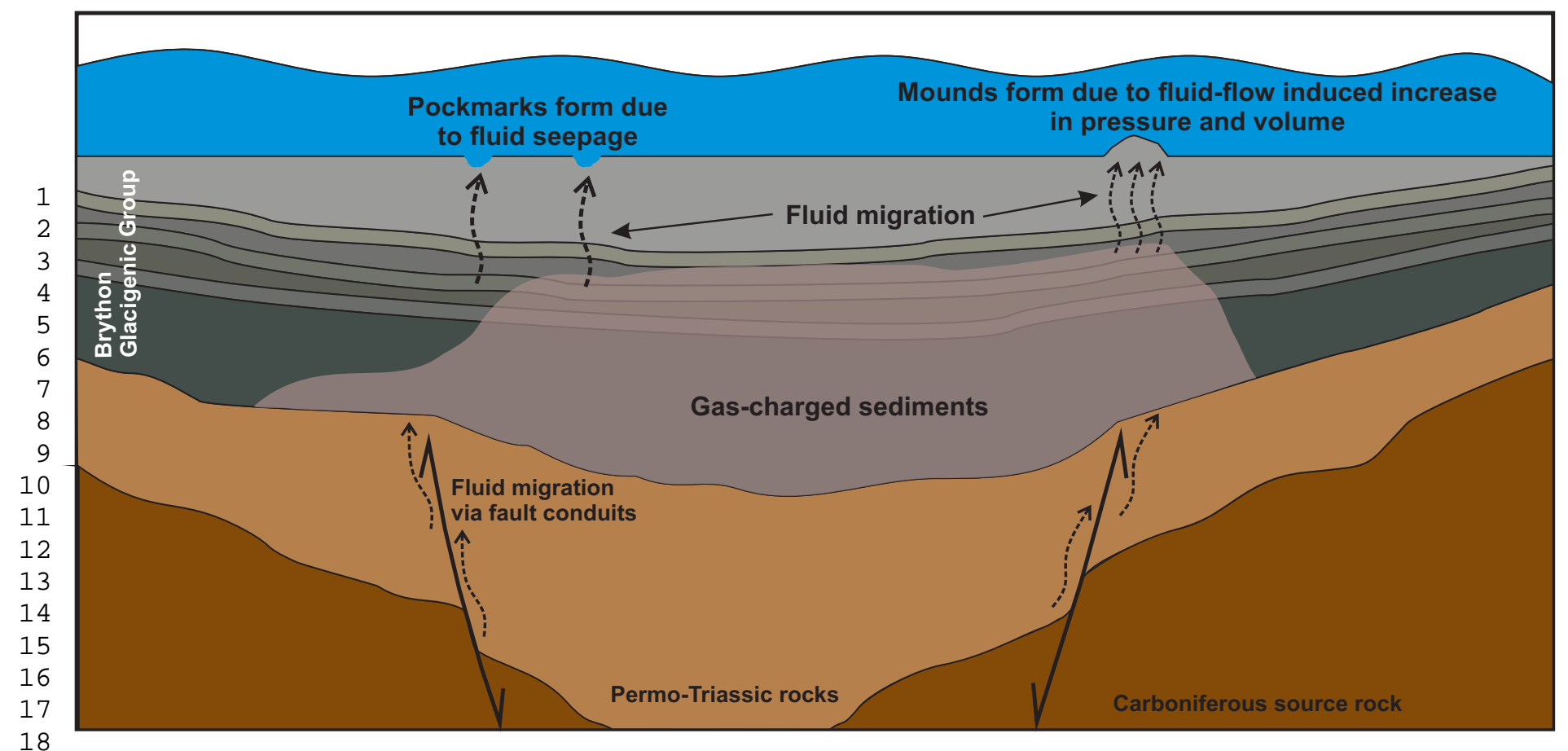




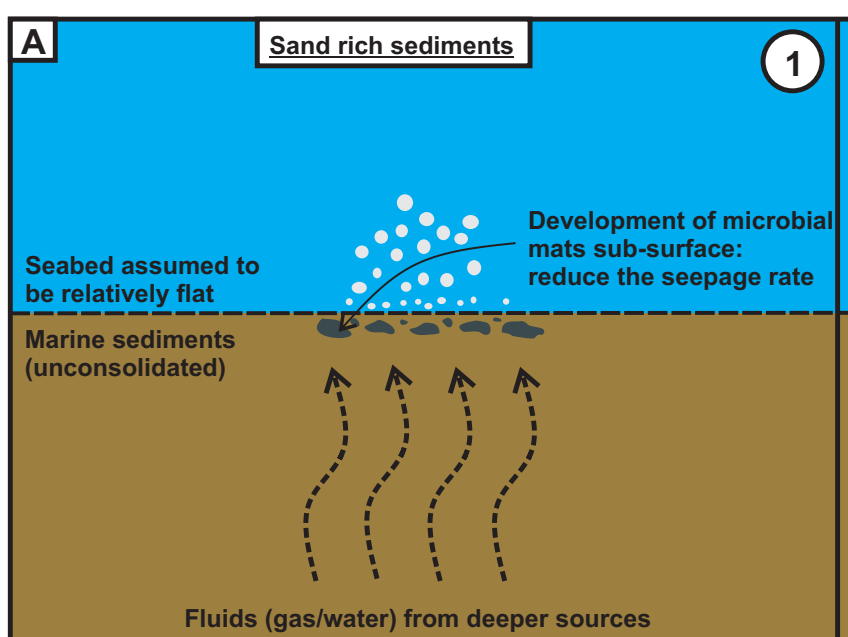

Fluid seepage from the subsurface and bottom currents surrounding

the carbonate crust reworks/erodes

the un-cemented seafloor sediments

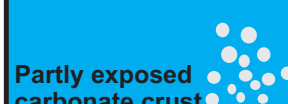

carbonate crust 0.8

$\therefore$

rip
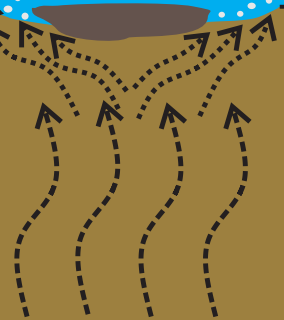

Fluids (gas/water) from deeper sources

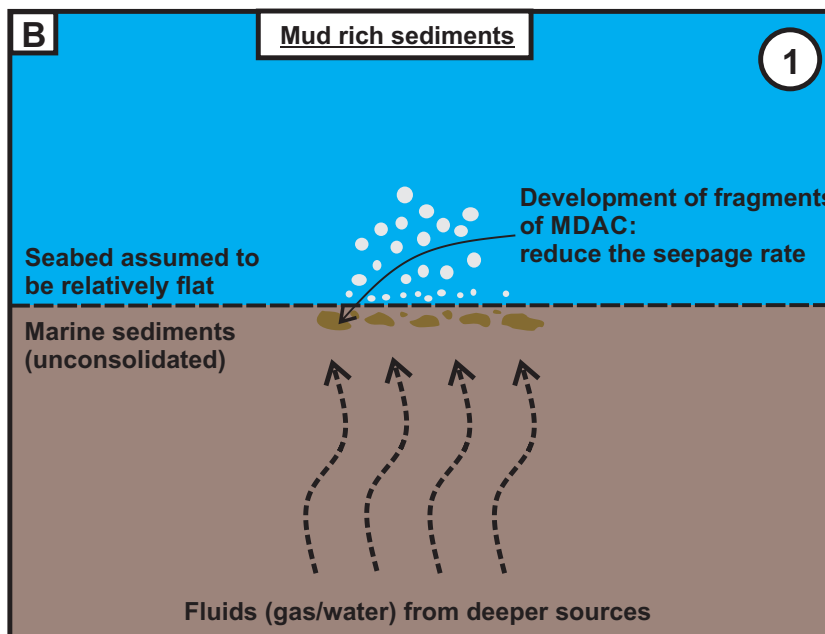

Further bulging out of carbonate crust

mound, development of fractures within the crust

(3)

Rupturing of mounded carbonate crust:

formation of crater-like depressions
Development of carbonate crust:

and diverges the seepage location

Limited seeapge around the crust

Fluids (gas/water) from deeper sources

(3) Focused fluid flow surrounding the
carbonate crust leads to the formation of pockmark with carbonate crust

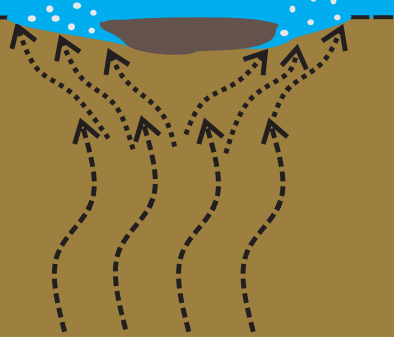

Fluids (gas/water) from deeper sources

Deveiopment of sealing carbonate

crust at the sediment-water interface:
almost seals seepage at this location

and diverges the seeping fluids

Limited seeapge around the crust

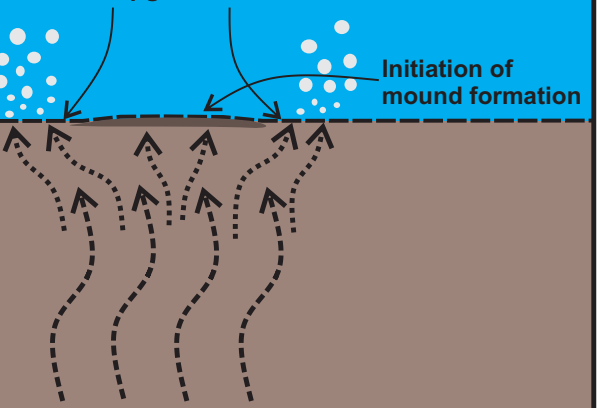

Fluids (gas/water) from deeper sources

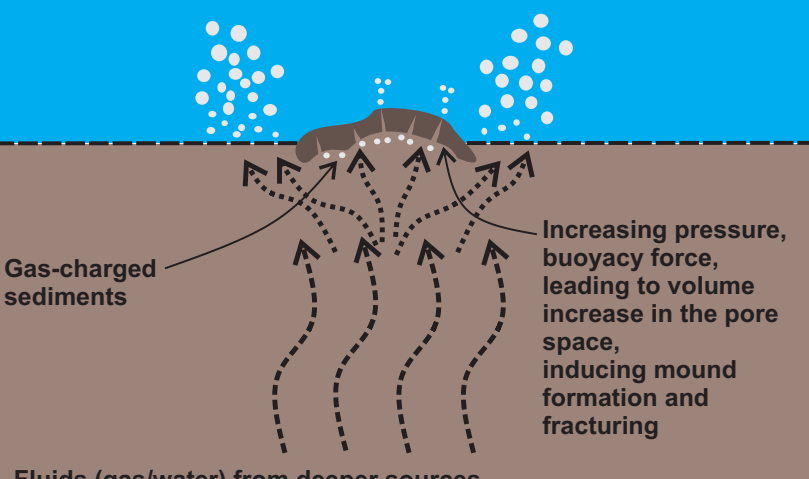




\section{Table 1}

\begin{tabular}{|l|l|l|l|}
\hline Survey & Year & Area & Data \\
\hline CV09_05 & 2009 & WISMB/Lambay Deep & MBES (EM3002D) bathymetry \& backscatter \\
\hline CV09_26 & 2009 & WISMB & $\begin{array}{l}\text { MBES (EM3002D) bathymetry \& backscatter, } \\
\text { Geo-Source 400 sparker }\end{array}$ \\
\hline CV10_01 & 2010 & WISMB/Lambay Deep/CFZ & MBES (EM3002D) bathymetry \& backscatter \\
\hline CV11_10 & 2011 & Queenie Corner & SES 5000 pinger \\
\hline CE14_01 & 2014 & Lambay Deep & Geo-Source 400 sparker \\
\hline CO24_18 & 2018 & Queenie Corner & MBES (EM3002) bathymetry \& backscatter \\
\hline
\end{tabular}


Pockmark Table
Click here to download Supplementary Material (for online publication only): S1_Pockmark_table.docx

Pockmark Table
Click here to download Supplementary Material (for online publication only): S1_Pockmark_table.docx

Click here to download Supplementary Material (for online publication only): S1_Pockmark table.docx

(2)

.

(1)

(2)

(1)

(1)

.

.

.

.

.

.

.

.

.

.

.

.

.

.

.

.

.

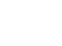

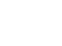

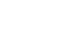

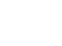

.

.

.

.

.

. 
Gas Parameters Table
Click here to download Supplementary Material (for online publication only): S2_Gas_table.docx

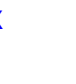


Queenie Corner Grab Sample
Click here to download Supplementary Material (for online publication only): S3_Queenie_Corner_grab.jpg 
Mark Coughlan: Conceptualisation, Investigation, Formal analysis, Writing - Original Draft, Visualization Srikumar Roy: Conceptualisation, Formal analysis, Methodology, Writing - Original Draft, Visualization Conor O'Sullivan: Methodology, Formal analysis, Writing - Original Draft, Visualization Annika Clements: Investigation, Writing - Original Draft

Ronan O'Toole: Investigation, Data Curation, Supervision, Writing - Review \& Editing

Ruth Plets: Investigation, Supervision, Data Curation, Writing - Review \& Editing 


\section{Declaration of interests}

$\bigotimes$ The authors declare that they have no known competing financial interests or personal relationships that could have appeared to influence the work reported in this paper.

$\square$ The authors declare the following financial interests/personal relationships which may be considered as potential competing interests:

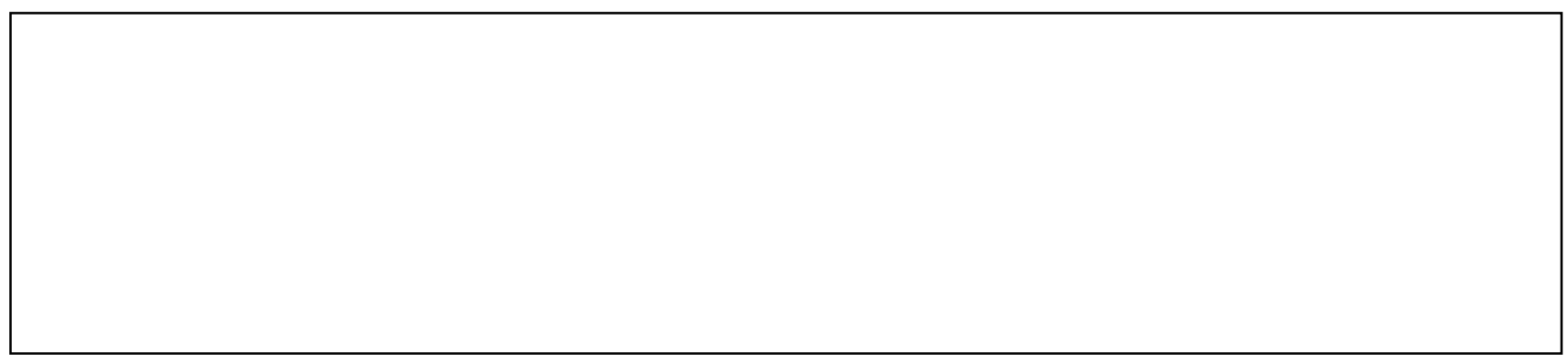

